日槜理誌 $55,1390 \sim 1429$ (1959)

\title{
精製痘苗の薬理学的研究
}

\author{
天野和夫 \\ （横浜市立大学医学部薬理学教室〔主任 由辺教授〕） \\ （昭和 34 年 8 月31日受付[特]）
}

\begin{abstract}
緒
需

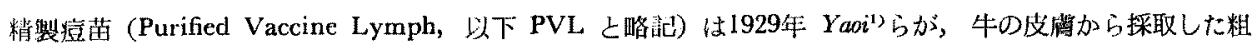
苗を精留して得た痘苗であって，我が国で行われている現行種痘法の幾つかの点を改良し，天然痘の完全防止 を意図した皮下喠痘の目的のために創られたものであるが，PVLには，Yaoi，Arakaxeaのの報ずる如き天然痘に

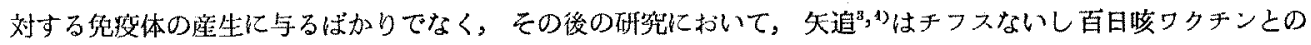

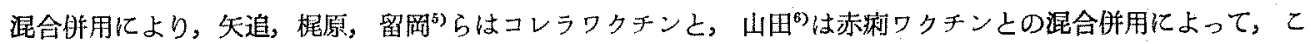

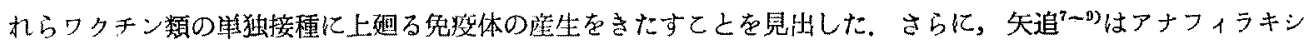

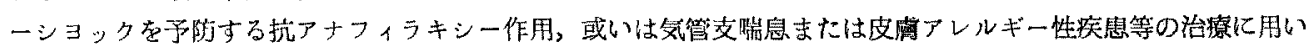

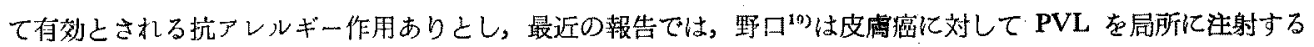

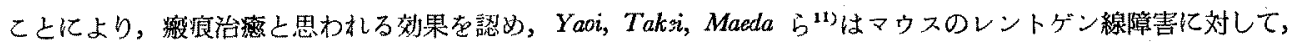

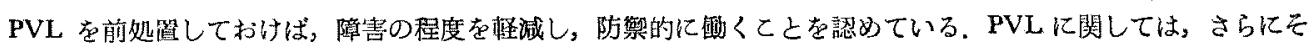

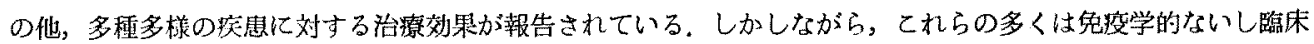
的治療効果に関するもので，PVLの菂理作用に関しては，その一部について相見 ${ }^{1214)}$ が報告しているのみで， 組織だった研究報告は見当らない，現在 PVL が跣床上種々の非伝染性疾患に刘しても治療薬として用いられて いる以上，その作用に関する基㩍的検索は当然行われなければならない。

PVL は牛痘 Virus を主体として含有しているが，その他若干の組織構成成分も含んでいるため，その作用

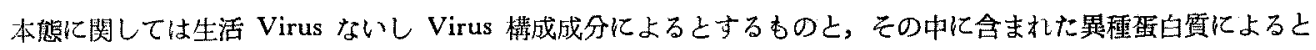

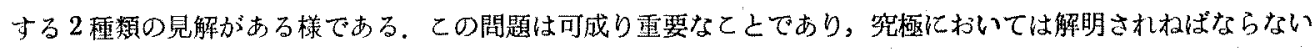

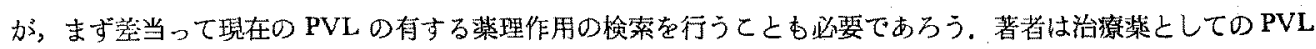

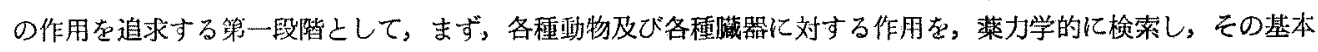
的性格を明らかにするてとを目的として本実験を行ったのである。
\end{abstract}

\section{PVL の性状その他について}

\section{I 、PVL の製法について}

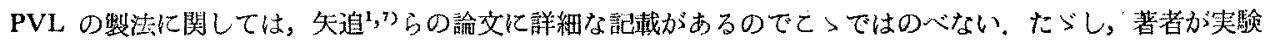
に用いた PVL は原法によって笠造された笠品とは少し異なった点があるので。それを記して断ってわきたい.

著者の使用した PVL 法染病研究可において，同一原料粗苗より創られたあのでするが，その製造過程に おいて，原法で行う石油エーテル抽出操作が省かれており，加製品に石岑酸及び膠を加えてない，この 2 点が 通常の製品之相違する。石油エーテルを以て抽出する操作学省いた理由は，近時との過程を省略したものつ方が， 臨休上より有效であるとの声があり，かつる製品が主として用いられていることによる．また，石炭酸及び凌の 添加を省いた理由は，乙れらのあのが，PVLの効力を保持するために，一種の安定剂として加えられているむ 


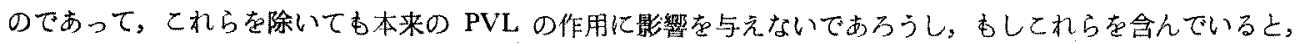
却って灌流奏験などに影響を与えはしないかと若えたからである。

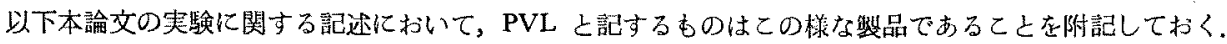

\section{H.PVL の一般諸性状}

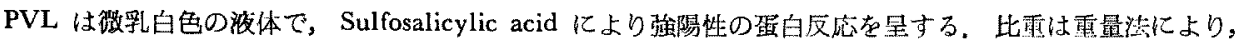

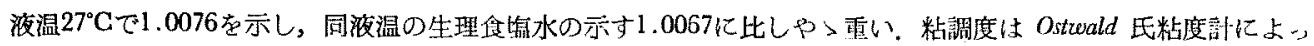

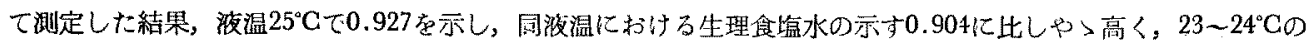
蒸渭水の示す值に近いものであった.

\section{PVL の現行力価検定法}

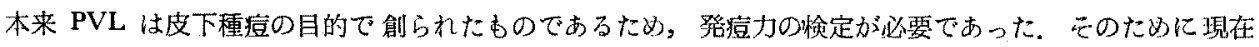

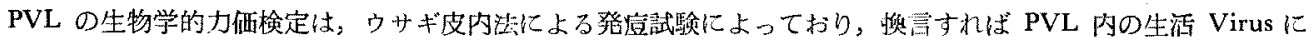

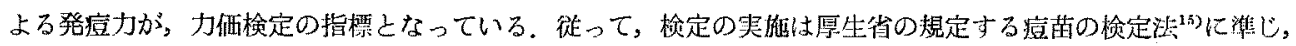

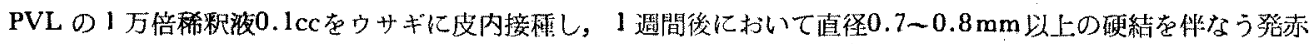

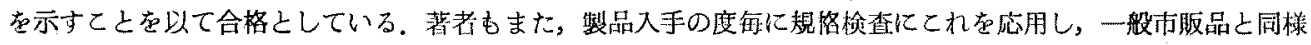
1 万倍桸䣋によって規定の発痘力を有するものであることを確めた。ささらに，PVL なセロファン膜に入れ，蒸

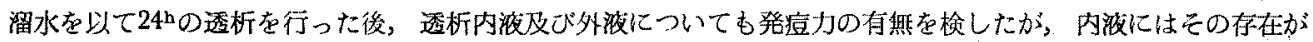
認められたのに対し，外液には認められなかった。

伝染病研究所より提供された PVL は，予め堿菌した容量100ccの共栓瓶に分注し，栓を施した上に，さら

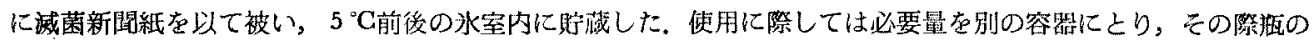

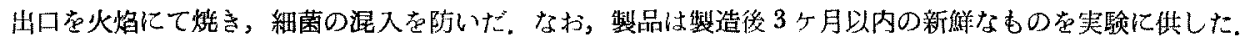

\section{PVL 以外の使用薬物}

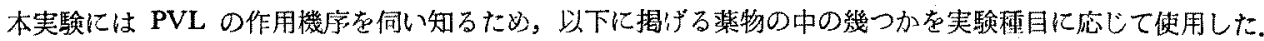
（）内にはをの略称を示した。 また，本文中における記述には便利な惯用名を多く用い，かつ㙁数を表わす言 葉隹原則として省略した。

Epirenaminae hydrochloridum (Adrenaline), Benzylimidazoline hydrochloride, Acetylcholini chloridum (ACh), Atropinae sulfas, Eserinae salicylas, Neostigmini methylsulfas, Histamine dihydrochloride, Diphenhydraminae hydrochloridum, Morphinae hydrochloridum, Chloralis hydras, $\mathrm{BaCl}_{\mathfrak{y}}, \mathrm{MgSO}_{4}$. その他, 動物麻酷用には Methylhexabitalum solubile，Pentobarbitalum sodicum 及び Urethanum 局いた。 また Cholinesterase $は$ (ChE) Łした.

\section{実 酫 成 績}

\section{I. 全身作用}

\section{1. マウスによる実験}

体重20－30gの比悛的大型のマウス18匹を用い，PVL 0.5－1cc 在皮下，腹腔内及び静脈内に注射し，一方対 照動物しして8匹のマゥスに夫々同量の生理食虽水を注射して，两者を比校しつ〉全身症状を钼察した。

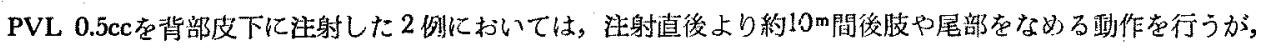

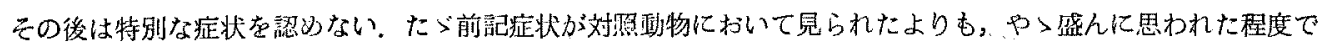
ある.

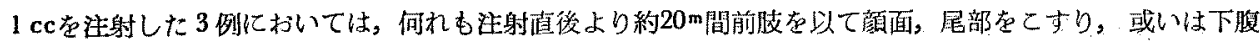

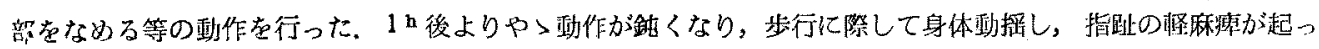

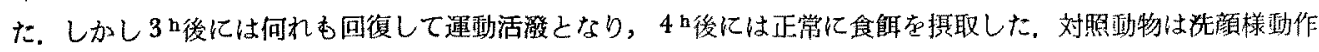
はするが，歩行障碍は全く起らなかっだ。 


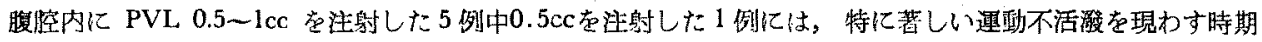

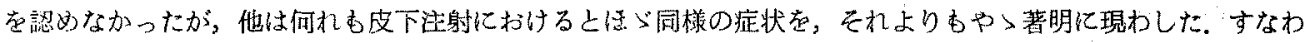

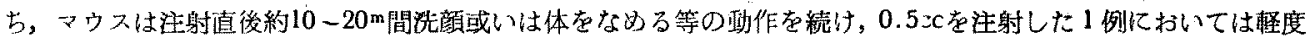

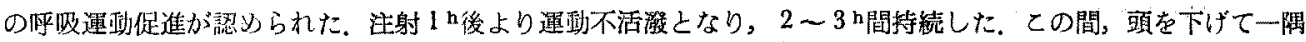

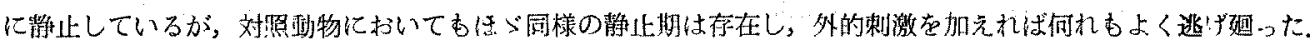

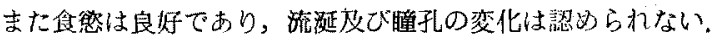

静脈内に0.5〜 1 ccを注射した 8例仍いては，PVL の作用は一圆明らか䛉認められた。しかし，注射直後

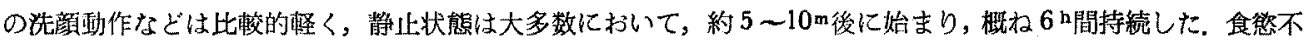

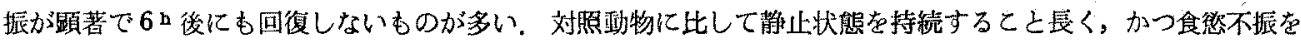

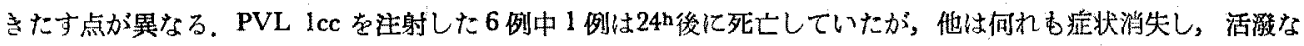
運動を行っていた。

全実験例を通じて病禁を起したものは 1 例も見なかった。

2. モルモット，ウサギ及びネコによる実験

体重200g前後のモルモット 4 匹，体重 $2 \mathrm{~kg}$ 前後のウサギ 5 匹，同じく $3 \mathrm{~kg}$ 前後のネコ 2 匹を使用し，前 2

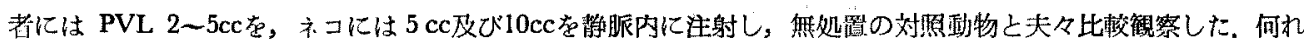
の㳩物も特に著しい変化を現わさなかったが，PVL $2 \mathrm{cc}$ 及び $5 \mathrm{cc}$ を注射したウサギ 2 例には，注射後 4 〜 $\mathrm{h}$ 問 において，呼财運動や〉促進し，幾分隐急の状加認められた。

3. 小 括

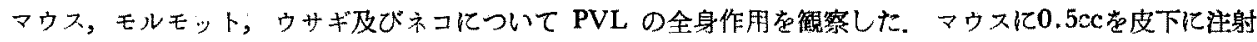

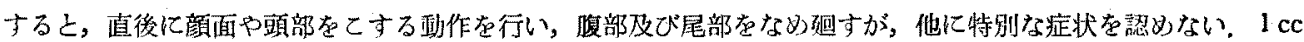

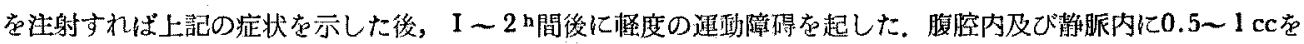
注射した場合は，運政不活潑の程度が一居著しくなり，多数咧においては長封間静止状態を続け，中には呼吸運

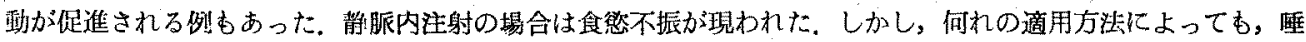

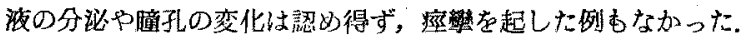

モルモット，ウサギ及びネコにおいては，PVL 2 10ccの静眽内注射によって，何ら症状を示さ如例が多か ったが，ウサギでは若干例仁呼四運動の促進されたあのがあった。

\section{I. 心臟に対する作用}

\section{1. 実験動物及ひ実験方法}

1）生体内心臓に関する実験法

a. トノサマカエル生体内心脉

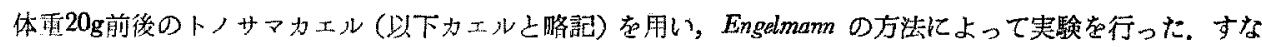

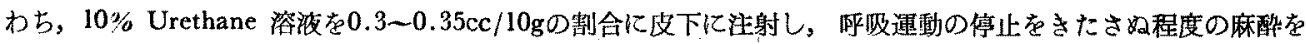

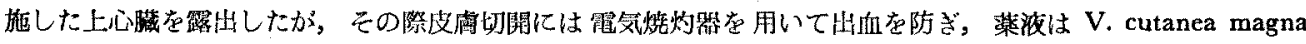
または V. femoralis に注射した。

\section{b. ウサギ生体内心瀻}

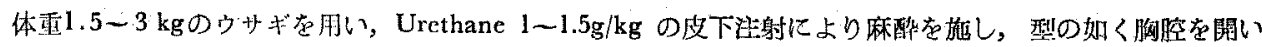

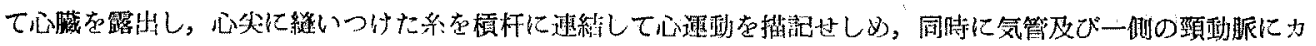

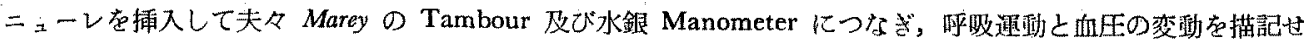

しるた。楽液の注入は耳静眽上り行った。

2) 摘出心䑋に関する実験法

\section{a. カエル及びガマ摘出心臟}

体重20g前後の力エルを用い，八木法及び田村・小林法により摘出心臟に対する作用を険しだ，八木法にわ ける静脈カニューレ内液量は $2 \mathrm{cc}$, 圧は $5 \mathrm{~cm}$ 水柱とし，動脈圧は $5 \mathrm{~cm}$ 水柱とした，田村・小林法では V. cava 
posterior よりする灌流液の圧を約 $2 \mathrm{~cm}$ 水柱，流入量は約 $1 \mathrm{cc} / \mathrm{min}$ とし，流出力二ューレを插入した Aorta dextra の圧は $5 \mathrm{~cm}$ 水柱とした。 なおその他，体重200 300gのガマ心臓を摘出し，八木法によって央験を行っ た. この実験における静脈カニューレ内液量は $3 \mathrm{cc}$, 圧は $2.5 \mathrm{~cm}$ 水柱とし, 動脈カニューレの圧は $5 \mathrm{~cm}$ 水柱を した.

以上の各実験法において灌流液としては，原則としてカエレ用 Ringer 液に0.8\%の割合に Glucose を加えた あのを用いたが，ガマ心八枮実験においては0.001\%の割合に Heparin を加えたガマ血液による灌流実験をも 併せて行った，薬液は八木法においては灌流液に注加したが，これには予め注加す心゙き薬液之同量の Ringer 液 を添加し，てれによる影響のないことを確めておいた．田村・小林法では煤煙紙上に，心運動の外に動脈力二ュ ーレより流出する液滴の数を電気滴数計によって描記せしめた. PVL の作用は急激であって，投与直後にすて に現われ，その後も心臟の機能は刻々变動を示すので，心裁より流出する液量を分時搏出量として計量したので は，細かい変化を捕えることが出来ない，従って，著者は搏出量の增減を単位時間内における流出液滴数の増減 を以て判定した，因みにその20滴はほづ1 cck相当する。䓠液は流入用静脈力ニューレに連なるゴム管内に注射 した.

\section{b. モルモット及びウサギ摘出心藏}

体重200－300gのモルモット及び体重1.5〜3 kgのウサギを用い，Langendorf-Gunn 法により実験を行った. 灌流圧は $70 \mathrm{~cm}$ 水柱前後とし，流出量は $20-30 \mathrm{cc} / \mathrm{min}$ とした，流出液滴は電気滴数計に導き，その数を心運動 と共に描記せしめ, 心冠灌流液量の增減をこれによって判定した。 この場合，この20滴はほメ゙9.5cck相当した。

\section{2. 実験成縝}

1）生体内心臓に対する作用

a. カエル生体内心㖑

総実験例12例のうち，PVL 0.1cc 静脈内に注射した 3 例では，振币及び搏㢦数に殆んど変化が認められな い. $0.2 \mathrm{cc}$ 注射した 9 例中 5 例には軽度の变化が認められたが，他の 4 例には殆んど变化が現われなかった。 変化を認め得た例のうち1例は，注射直後数分の間に振门の柽度の増大につぐ減少及び搏動数の僅微な減少が起 った（第 1 図及び第 1 表）が，他の 4 例では何れ屯振巾の变化は軽度であり，徐々に振巾を減して行くため，そ れが PVL の作用によるものか或いは自然的のものかの触实な判断は困難であった，搏動数の变化むまた泽度で， 1 例では注射直後より約 $10 \mathrm{~m}$ 間や〉搏動数が増加したが，他は何れも徐 タに僅かずつ減少した。

何れにせよこの実験条件では，PVL の心臟に対する作用は極めて 弱く，顕著な作用を認めなかった。

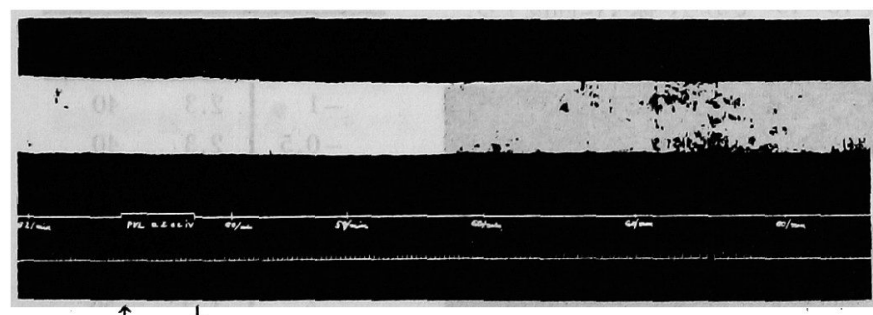

PVL $0.2 \stackrel{\downarrow}{\downarrow}$ 静眽内注射

第1図。カエル生体内心藏に対する PVL の作用 (Engelmann 法). $15 / X^{~} 57,23^{\circ} \mathrm{C}, 25 \mathrm{~g} ， \hat{\delta} ， 10 \%$ Urcthane $35 \mathrm{mg} / 10 \mathrm{~g}$ 皮下注射， 時標 $6^{\mathrm{s}}$, PVL 0.2cc 静脈内注射 (第 1 表参照), 上向虻収縮.
第 1 表. 力エル生体内心臟に 対する PVL の作用 (Engelmann 法).

\begin{tabular}{|c|c|c|}
\hline 洔間(分) & $\begin{array}{c}\text { 振巾! } \\
(\mathbf{c m})\end{array}$ & $\begin{array}{l}\text { 搏動数 } \\
\text { (毎分) } \\
\end{array}$ \\
\hline-1 & 3.2 & 62 \\
\hline 処置 & \multicolumn{2}{|c|}{$\leftarrow$ PVL $0.2 \mathrm{cc}$ 竫脈内注射 } \\
\hline$\therefore 0.5$ & 3.2 & 62 \\
\hline 1 & 3.2 & 61 . \\
\hline 2 & 3.3 & 60 \\
\hline 3 & 3.3 & 60 \\
\hline 4 & 3.2 & 59 \\
\hline 5 & 3.1 & 59 \\
\hline 6 & 3.0 & 60 \\
\hline 7 & 3.1 & 60 \\
\hline 8 & 3.2 & 60 \\
\hline 9 & 3.2 & 60 \\
\hline 10 & 3.1 & 60 \\
\hline
\end{tabular}

(第 1 図参照),

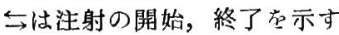




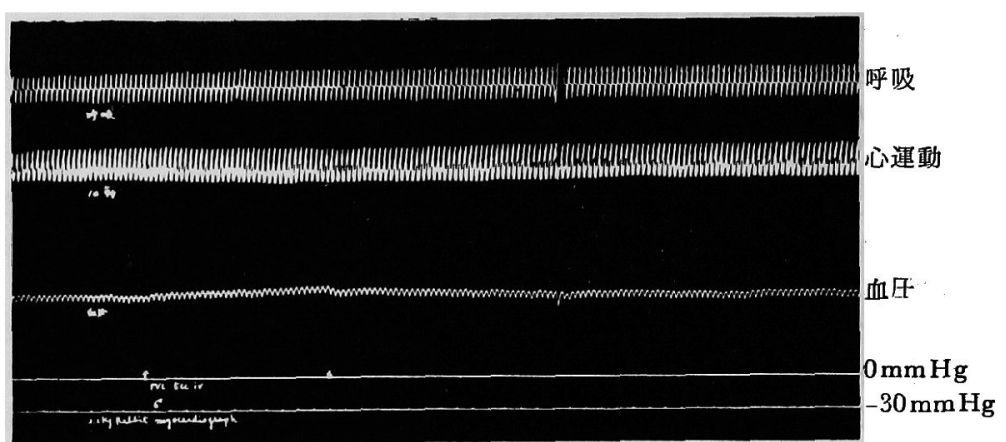

PVL 5cc 静脈内注射

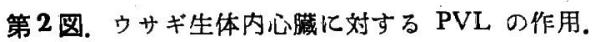

$6 /$ 调 $57,13^{\circ} \mathrm{C}, 2.2 \mathrm{~kg} ， \hat{\delta}, 10 \%$ Urethane $1 \mathrm{~g} / \mathrm{kg}$ 皮下注射， 時標6s, PVL $5 \mathrm{cc}$ 静脈内注射 (第 2 表参照).

\section{b. ウサギ生体内心臓}

総実験例 5 例のうち PVL $1 \mathrm{cc}$ を静脈内に注射した 1 例では，心運動に何ら変 化を認めない，他の 4 例については $5 \mathrm{cc} の$ 注射を試みたが，その中 3 例に認められ た主変化は搏動数の減少であり，振巾は数字的には僅微な増大を示しているが， の程度の変化では明らかでない（第 2 図及び第 2 表）. この搏動数の減少は 2 例で

第 2 表

ウサギ生体内心臓化 対する PVL の作用 (第 2 図参照).

\begin{tabular}{|c|c|c|}
\hline $\begin{array}{l}\text { 時間 } \\
(\text { 分) }\end{array}$ & $\begin{array}{l}\text { 振巾 } \\
(\mathrm{cm})\end{array}$ & $\begin{array}{c}\text { 搏動数 } \\
\text { (毎30秒) }\end{array}$ \\
\hline-1 & 1.6 & 120 \\
\hline 処置 & \multicolumn{2}{|c|}{$\begin{array}{l}\text { PVL } 5 \mathrm{cc} \\
\leftarrow \text { 脈静内注射 }\end{array}$} \\
\hline 0.5 & 1.7 & 102 \\
\hline 1 & 1.8 & 108 \\
\hline 1.5 & 1.7 & 106 \\
\hline 2 & 1.7 & 108 \\
\hline 2.5 & 1.8 & 108 \\
\hline 3 & 1.7 & 110 \\
\hline 3.5 & 1.7 & 110 \\
\hline 4 & 1.7 & 106 \\
\hline 4.5 & 1.7 & 106 \\
\hline 5 & 1.7 & 108 \\
\hline
\end{tabular}

岕注射の開始, 終了を示す。. は 3〜 $7 \mathrm{~m}$ 持続した後回復し，他の例では更にそれ以上持続した. 残る 1 例には振门及び搏動数共に殆んど変化 を認めなかった，本実験においても PVL の心臓に対する影響は，搏動数の減少が殆んど唯一のあのであり，振 巾の増大は明らかでなく，全体として見れば心藏に対する影響は著しいものではなかった。

2) 摘出心臓に対する作用

a. カエル及びガマ摘出心臓

i）八木法による実験

PVL のカエル心臟に対する作用を八木法によって調べた．実験は秋季に行い，実験例数は18例である．何 れもほ>゙同一の傾向を示したので，以下 PVL 0.2ccを投与した例について のべる.

すなわち，投与直後より心臟の搏動振巾は縮小し始め，この際収縮拡 張共に不良となる，振门縮小期間は凡そ10〜 15mであり，徐々に回復する.

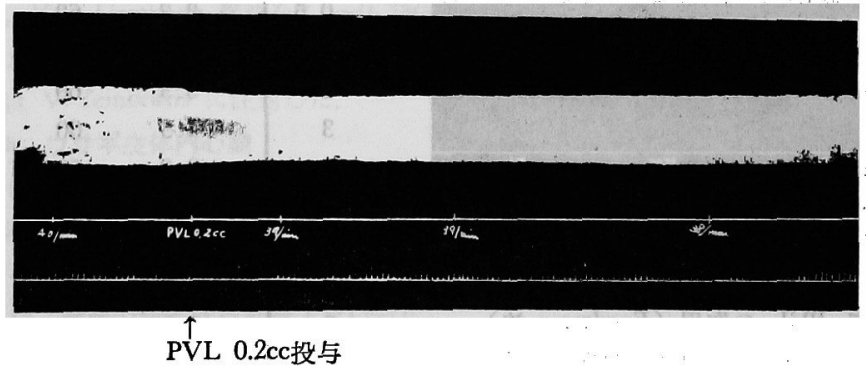

第3図. 力エル摘出心臟に対する PVL の作用 (八木法).

$19 / \mathrm{X}$ '57，20 $0^{\circ}$ ，PVL $0.2 \mathrm{cc}$ 投与（第 3 表参照）, 上向は収縮, 時標 $6 \mathrm{~s}$ 。

第 3 表. 力エル摘出心臟に 対する PVL の作 用 (八木法)。

\begin{tabular}{|c|c|c|}
\hline 時間(分) & $\begin{array}{l}\text { 振巾 } \\
(\mathbf{c m})\end{array}$ & $\begin{array}{l}\text { 搏動数 } \\
(\text { 毎分) }\end{array}$ \\
\hline-1 & 2.3 & 40 \\
\hline-0.5 & 2.3 & 40 \\
\hline 処置 & $\leftarrow$ PVL & $0.2 \mathrm{cc}$ 投与 \\
\hline 0.5 & 2.0 & 39 \\
\hline 1 & 1.95 & 39 \\
\hline 2 & 1.9 & 38 \\
\hline 3 & 1.9 & 39 \\
\hline 4 & 1.9 & 39 \\
\hline 5 & 1.9 & 39 \\
\hline 6 & 1.9 & 38 \\
\hline
\end{tabular}

（第 3 図参照）, ↔は薬物投与時期を示す。 
また搏動数は僅かながら減少の㑯向を示す様䎲思われた（第 3 図及び第 3 表）.

次に血液が PVL の効力にいかなる影響を与元るかを見るために，心蔵を人工栄養液を以て灌流した場合と， 血液を以て灌流した埸合とについて PVL の作用強度を比校する実験を行った。 “の実験にはガマの心臟を使用 した. ガマ摘出心臓を八木法により Ringer 液を以て灌流した実験にわいて，PVL 0.5ccを作用せしめると $10 \mathrm{~m}$ 間 の钼察時間において，振巾は持続的に縮小したが，搏㲜数は殆んど变化を現わさない，てれて比へて血液による 灌流実験では，同量の PVL を用いてその作用は著しく弱められ，振巾縮小程度は弱く，心運動抑制作用の強度 が堿弱する結果を示した。すすかち；PVL 0.5ccを作用せしめた場合に最も強く縮小した振巾の，投与前振门に

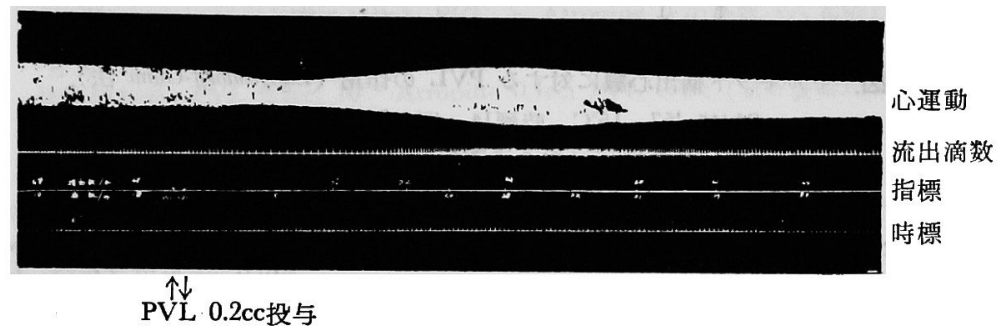

第 4 図. カエル摘出心臟に対する PVL の作用 (田村・小林法).

$11 / \mathrm{XI}{ }^{\prime} 58,21^{\circ} \mathrm{C}$, 時標 $6^{\mathrm{s}}$, 静脈圧 $2 \mathrm{~cm}$ 水柱, 動脈圧 $5 \mathrm{~cm}$ 水柱, 上向は収縮, PVL $0.2 \mathrm{cc}$ 投与 (第 4 表参照).

対する減少率を，Ringer 液灌流例及び血液灌流例各 5 例について の各平均值を比較すると，前者では約 $31 \%$ 減少を示すのに対 し，後者では僅かに約 $7 \%$ 減少を示すに過ぎなかった.

ii）田村・小林法による実験

カエル心臟に対する PVL の作用を八木法によって検索した 結果，収縮並びに拡張共に或る程度減弱し，かつ搏動数にも多少 の诚少傾向を認めたので, その際の単位時間内における搏出量の 変動を知るために，田村・小林法によって実験を行った，実験は 秋季に行い，総実験例数は10例である．P /L 0.2cc を投与した結 果，各例とも明瞭かつ同一の傾向を示し，しかも八木法による成 績とは異なった成績を示した。 まず心運動については，約 $30 \mathrm{~s}$ 後 より収縮払張共に次第に不良となり始め，そのため振巾は縮小す る. その度合は $2 \mathrm{~m}$ 前後において最む著しく, その後は徐々に回 復して $5 \mathrm{~m}$ 前後には心゙旧に復する。.乙れについで逆に振门は収縮 拡張共に投与前に比し可成り著しい增大をきたし，4〜 $5 \mathrm{~m}$ 持続 した後再び徐々に減弱して旧に復し，或いは更に減少する傾向を 示した. この際搏動数は振门縮小期にや〉増加し，振巾増大期に は投与前より減少し，その後振巾の復旧ないし減少と共に回復傾 向を示した，また，流出滴数は振巾縮小期に著しく減少し，その 最盛時には対照時に比し約 $70 \%$ 減少を示し, 振门回復期より增 大期にかけては，反対に著しく增加して同じくその最盛時には約 50\%の増加を示した. その後振门の回復と共に旧に復するが，最 後には振巾搏動数共に対照時に比べて減少し, 綜合結果として流 出滴数もまた再転して 対照時以下に 減少した（第 4 図及び第 4 表),
第 4 表. カエル摘出心臓に対する PVL の作用 (田村 - 小林法).

\begin{tabular}{|c|c|c|c|}
\hline 時間(分) & $\begin{array}{l}\text { 振巾 } \\
(\mathbf{c m})\end{array}$ & $\begin{array}{l}\text { 搏動数 } \\
\text { (毎分) }\end{array}$ & $\begin{array}{c}\text { 流出滴数 } \\
\text { (毎分) }\end{array}$ \\
\hline-1 & 2.4 & 68 & 19 \\
\hline-0.5 & 2.4 & 68 & 18 \\
\hline 処置 & \multicolumn{3}{|c|}{$\leftrightarrows \mathrm{PVL} \quad 0.2 \mathrm{cc}$ 投与 } \\
\hline 0.5 & 2.2 & 69 & 12 \\
\hline 1 & 2.1 & 70 & 10 \\
\hline 1.5 & 1.7 & 71 & 7 \\
\hline 2 & 1.5 & 71 & 5 \\
\hline 2.5 & 1.4 & 72 & 6 \\
\hline 3 & 1.6 & 72 & 7 \\
\hline 4 & 1.8 & 72 & 10 \\
\hline 5 & 2.3 & 72 & 13 \\
\hline 6 & 2.9 & 64 & 20 \\
\hline 7 & 3.2 & 62 & 28 \\
\hline 8 & 3.2 & 62 & 25 \\
\hline 9 & 3.0 & 61 & 22 \\
\hline 10 & 2.7 & 60 & 21 \\
\hline 11 & 2.4 & 61 & 20 \\
\hline 12 & 2.4 & 61 & 17 \\
\hline 13 & 2.3 & 64 & 13 \\
\hline 14 & 2.2 & 64 & 13 \\
\hline 15 & 2.1 & 64 & 12 \\
\hline
\end{tabular}

(第 4 図参照)，20滴 $\fallingdotseq 1 c c$, ↔注射の開始，終了を示す。 


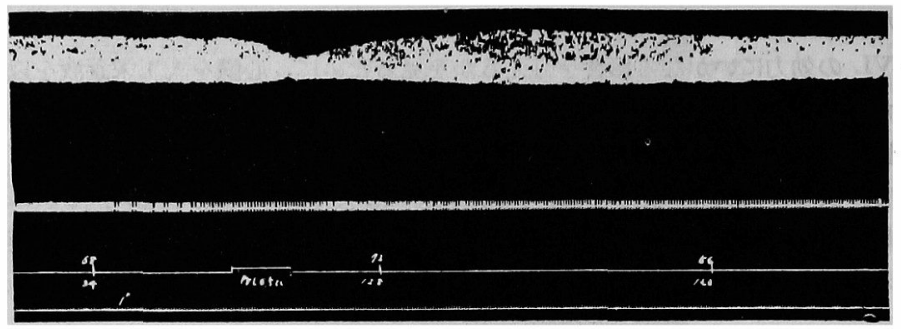

PVL $0.5 \mathrm{cc}$ 投与

第 5 图.モルモット摘出心炡に対する PVL の作用 (Langendorff-Gunn 法).

$24 /$ XII $57,15^{\circ} \mathrm{C}$, 時標 $1 \mathrm{~s}$, 压: $70 \mathrm{~cm}$ 水柱,

PVL $0.5 \mathrm{cc}$ 投与 (第 5 表参照), 上向は収縮。

\section{b. モルモット及びサザ摘出心脿}

PVL の温血動物摘出心藏に対する作用を モルモット14例及 びウサギ 9 例について観察した。両者共ほづ同一の反応を現わし たが，前者はより小量の PVL によく反応し，0.1ccを用いてウ サギ心蔵に0.5ccを用いた場合にほづ匹敵する反応を示した. し かし，モルモット心蔵の場合であ0.2〜0.5ccを用いた方が一㒸明 瞭に現われるから，こ〉にはその実験例 9 例についてのべる。 そ れらは何れもほら゙同様な 経過を辿ったから，その代表例として PVL $0.5 \mathrm{cc}$ を投与した 1 例をてつに揭げた（第 5 図及び第 5 表）. すなわち，PVL 投与直後著明な振门縮小と搏動数の減少が現わ れる，この際，収縮並びに拡張共に不良となるが，特に収縮が強 く抑制される. しかし，振巾む搏動数む直ちに回復して $1 \sim 2 \mathrm{~m}$ 後には，逆に振门の増大と搏動数の增加を現わす．この際す収縮 拡張共に増大するが，特に収縮の増大が著明である.そして4〜 $5 \mathrm{~m}$ 後には振门搏動数共に旧に復した. 心冠流出量は PVL 投与 直後における振巾及び搏動数の娍少之相伴なって一過性に減少寸 ろが，振门及び搏動数のなお娍少している時期に，天の回復に先 だって増加し始め，1 m 後には対照㭙よりも著明に増加し，その 後約 $1 \mathrm{~m}$ 持続した後止んだ.

以上の関係は大多数の例において見られたが，9 例中 2 例に おいては心運動抑制期が僅かに15s 前後持続したのみで, 直ちに 振门及び搏㗢数が増加に転じており，これらの例においては振巾 及び搏動数の増加之心冠流出量の増加之は，洔間的に何れが先行 したかを明膫に判定し得なかった。 また振巾の最高減少率は20〜 50\%，最高增加率は10〜40\%に入るのが大多数であるが，1例で は特に反応顕著であって，約 $75 \%$ の減少と約 $100 \%$ 増加を示した．最高滴数増加率は何れも10〜20\%の増加を 示した.

c. 他の薬物之の関係一特に Atropine に対する PVL とACh の態度

八木法における PVL の作用は ACh のそれと類似するかに見えるので，20例のカエル心臟を用いて両薬物 の作用を比較し，特に両者の Atropine に対する態度を観察した. 実験は秋季に行った.

まず PVL とACh の作用を比較すると，濃度10-8の ACh 溶液0.05ccを用いた場合，搏動数並びに振巾の
第 5 表.モルモット摘出心䑏に対する PVL の作用 (Langendorff-Gunn 法).

\begin{tabular}{|c|c|c|c|}
\hline 時間(分) & $\begin{array}{l}\text { 振巾 } \\
(\mathbf{c m})\end{array}$ & $\begin{array}{l}\text { 搏動数 } \\
\text { (毎分) }\end{array}$ & $\begin{array}{l}\text { 流出摘数 } \\
\text { (毎30愁) }\end{array}$ \\
\hline-1 & 1.7 & 144 & 33 \\
\hline-0.5 & 1.7 & 144 & 33 \\
\hline 処置 & \multicolumn{3}{|c|}{$\leftrightarrows \mathrm{PVL} 0.5 \mathrm{cc}$ 投与 } \\
\hline 0.5 & 0.8 & 134 & 30 \\
\hline 1 & 1.6 & 132 & 39 \\
\hline 1.5 & 2.0 & 138 & 36 \\
\hline 2 & 2.1 & 144 & 33 \\
\hline 2.5 & 2.0 & 150 & 33 \\
\hline 3 & 1.9 & 156 & 33 \\
\hline 3.5 & 1.8 & 150 & 30 \\
\hline 4 & 1.7 & 150 & 30 \\
\hline 4.5 & 1.7 & 150 & 30 \\
\hline 5 & 1.6 & 144 & 30 \\
\hline 5.5 & 1.6 & 144 & 30 \\
\hline 6 & 1.5 & 144 & 30 \\
\hline 6.5 & 1.4 & 144 & 30 \\
\hline 7 & 1.4 & 144 & 30 \\
\hline 8 & 1.4 & 144 & 30 \\
\hline 9 & 1.4 & 144 & 30 \\
\hline 10 & 1.4 & 144 & 30 \\
\hline
\end{tabular}

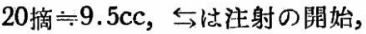
終了を示す (第 5 図参照). 


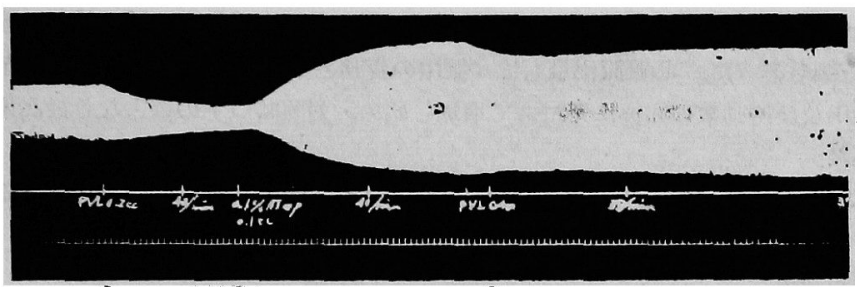

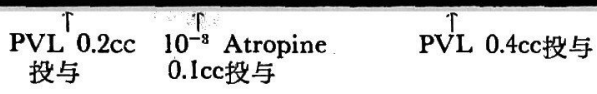

第 6 図. カエル摘出心贜に扣ける PVL と Atropine との拮抗 (八木法). $21 / \mathrm{X}{ }^{\prime} 57,16^{\circ} \mathrm{C}$, 時標 $6^{\mathrm{s}}$, 上向は収縮,

薬物投与順：PVL 0.2cc, 10-3 Atropine 0.1cc, PVL 0.4cc (第6 表参照).

第6表.カエル摘出心葴に扣けら PVL と Atropine との拮抗 (八木法).

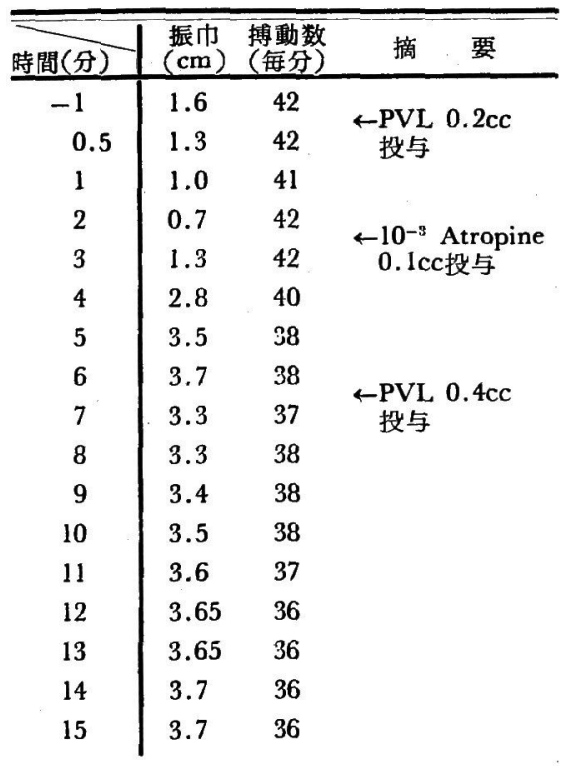

(第 6 図参照)，↔は薬物投与時期を示す.
減少が認められ，作用強度は PVL 0.2cc のそれより強いが 持続時間には大差がない. しかし濃度 $10^{-7}$ の ACh 溶液0.05 ccを用うれば作用持続は明らかに長くなる。

次に浱度 $10^{-4} の$ Atropine 溶液0.05cc以下の量を投与し た場合, 何ら心臟作用を認む得ないが, 溚度 $10^{-8}$ 溶液0.01ccで は時に振巾の増大を認め，0.05〜0.1cc を用うれば殆んど常 に振币の增大が認められる，との成績に基づき，濃度10-4の Atropine 溶液0.05ccを以て前処置すると，洤度 $10^{-7} \sim 10^{-5}$ の ACh 溶液0.1ccの現わすべき心倵抑制作用は全く遮断さ れるが，PVL 0.2ccの心㖑抑制作用は Atropine の影響を受 けることなく現われた，次に大量の Atropine の現わす心藏 作用之 PVL の作用との関係を検した。 まず PVL 0.2cc を 投与して心臓抑制作用の現われた封期に, 濃度 $10^{-3}$ の Atropine 溶液0.1ccを投与すると，Atropine は PVL の作用に打 勝って著明な強心作用を現わす。 しかるにこの時 PVL 0.4cc を投与すれば，程度は弱いながら Atropine に拮抗して PVL の心臟抑制作用が認められた（第 6 図及び第 6 表）。

\section{3. 小 括}

PVL の心臟作用をカエル，ガマ，モルモット及びウサ ギを用い，生体内心臟之摘出心臓とについて観察した。

生体内心藏に対しては冷血，温血動物共に著明な作用は 認め難い，殊に泠血動物においては結果が明膫を欠き，僅か

に1例において注射直後一過性に軽度の振巾の增減と軽度の搏動数の減少とが記録されたのみ.で，他は作用の有 無の判定が困難であった，温血動物においても振巾増大は，あるかないかの程度でいうに足りないあのであり， 主な変化は搏動数の減少であった.

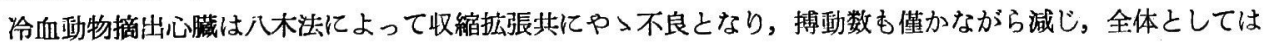
終始心臓抑制作用が現われた．田村・小林法によってはこれと異なり，初期抑制作用と後期促進作用とが著明に 現われ，心搏出量は振币の縮小増大とほら゙一致して変亚し，初期には対照時に比し最高約70\%の娍少を示し，つ いで対照時以上に増加して最高約 $50 \%$ の増加を示した。

モルモット及びウサギ摘出心蔵は共に PVL に対してはく同様に，かつ良く反応したが，前者は特に PVL

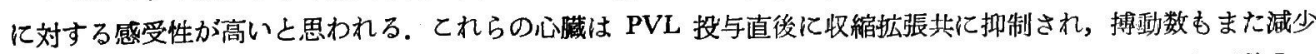
するが, 約 1 - $2 \mathrm{~m}$ 後には逆に促進作用に転じ，収縮拡張共に増大し，搏動数も増加する，そして全経過数分に 


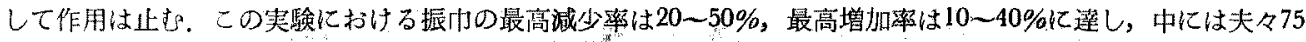

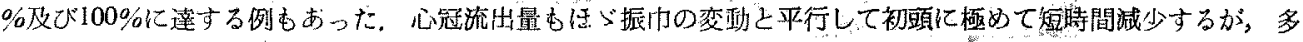
くの例にわいては振巾及び搏㲜数の回復に先だって増加し始め，刘照時以上の值となり最高堌加率10〜20\%を示 し, かで日に復した.

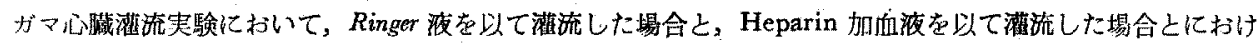

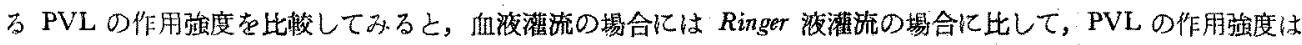
著しく減弱さ机るの認めた。

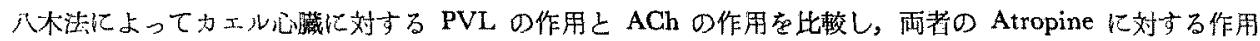

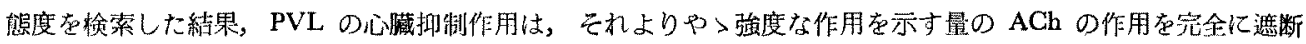

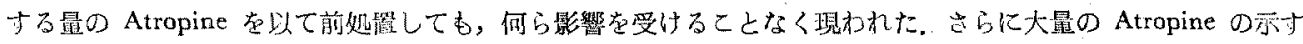

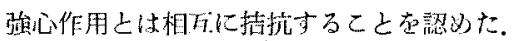

\section{II. 血管に対する作用}

\section{1. 実験動物及び実験方法}

\section{1）麻醉ガマ後肢血管淮流法}

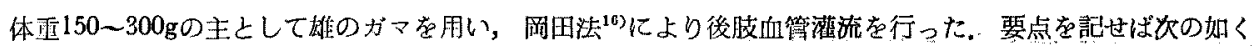

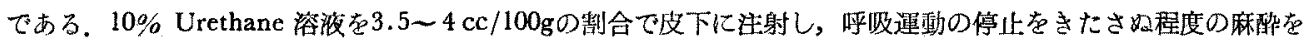

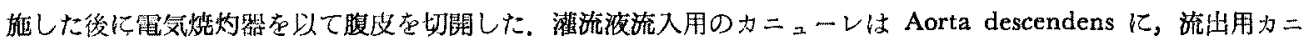
ューレはV. abdominalis に挿入した. 灌流液には0.8\%の制合に Glucose を加えた Ringer 液に $\mathrm{O}_{2}$ を飽和した ものを使用した，少数例についてはさらに10-7の割合に Adrenaline を加元て实験を行ったもの屯ある．灌流压

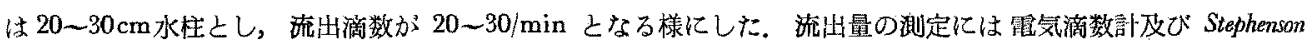

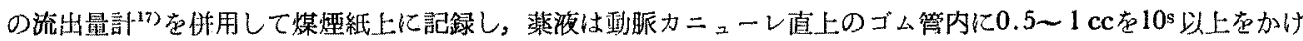

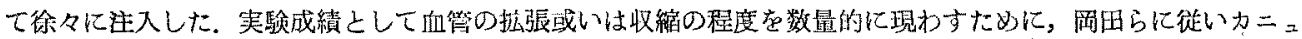
一レより落下寸る流出液激数を注射前後にわいて比校し，前者に対する後者の滴数の百分比をとり，滴数增㳦の

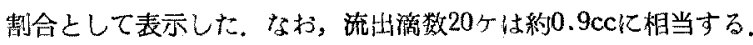

\section{2) 麻醉ガマ腸間膜血管灌流法}

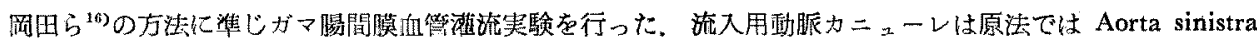
に挿入するが，漖者は個体によって Nn. splanchnici を損照する恐れのない晹合には，Aorta の代りに A. me-

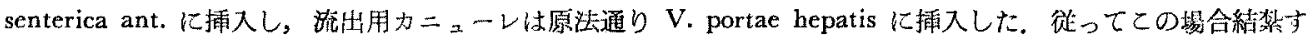
る血管は A. coeliaca, A. lienalis 及び A. coeliacomesenterica $の$ 勁脈カニューレ上部と，小晹上下部絬倠に際

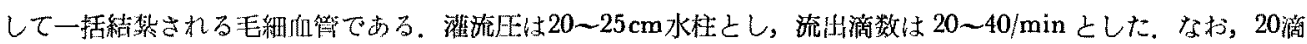

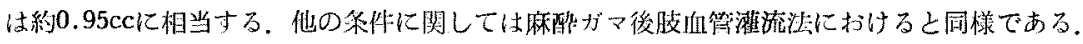

\section{2. 実験成績}

\section{1）麻醉ガマ後肢血管に対する作用}

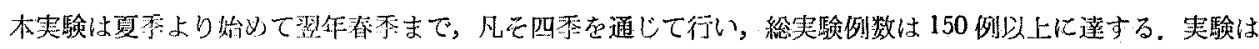
ACh 及び Adrenaline $の$ 作用と比喥しつっとれらと平行して行ったが，特に ACh によって拡涱明らかな標本 のみを用いた。

\section{a. PVL の作用}

盛夏時にはガマの状態が恶く，安定した灌流が望めない，従ってての季に PVL の投与を行った10例の実験 ておいては，磪然とした結果を得られなかった。

夏季の終りより秋否に至机保，PVL 0.5cc またはこれ以下の量を与兄て著明な血管拡張作用が認》られた。

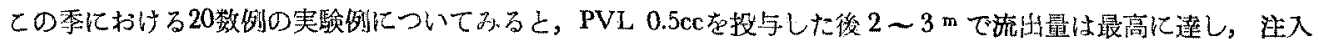
前に比すれば30～50\%の增加を示し，その㣪徐《に減少して約 10 後に旧に復した（第 8 図A）。さらに PVLの

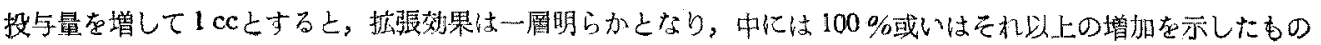



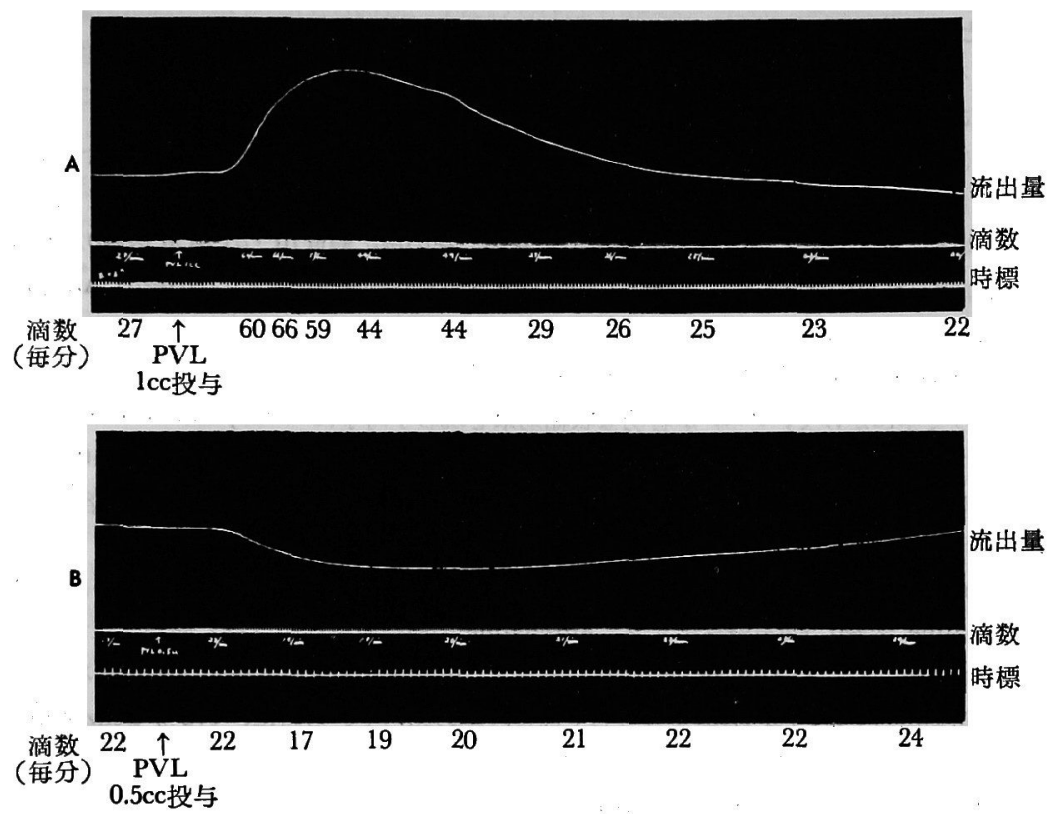

第 7 図. 麻醉ガマ後肢血管に対する PVL の作用.

$10 \%$ Urethane $3.5 \mathrm{cc} / 100 \mathrm{~g}$ 皮下注射, 圧: $25 \mathrm{~cm}$ 水柱, 20 滴 $\div 0.9 \mathrm{cc}$, 曲線の上昇は游数增加, 血管拡張を示す.

A : $13 /$ X ' $57,21^{\circ} \mathrm{C}, 200 \mathrm{~g}$ ，占，PVL lcc投与，時標6 (秋季実験).

B : $14 / \mathrm{XII}$ ' $57,16^{\circ} \mathrm{C}, 220 \mathrm{~g}$, 合, PVL $0.5 \mathrm{cc}$ 投与, 時標 $10^{\text {' }}$ (冬季実験).

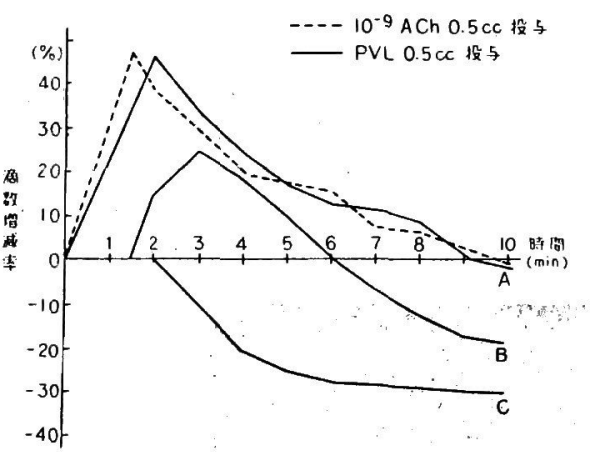

第 8 図. 麻醉ガマ、後肢血管に対するPVL 及び ACh の作用比較。

A：初夏及び秋季に抽引拡張作用。

B : 秋, 冬季に扣ける拡張作用より収縮作用への 移行.

C : 䈗冬及び春季に扣ける収縮作用。

以上は PVL $0.5 \mathrm{cc}$ 投与後の滴数増減率により判定. …… : 春, 秋季に扣りる $10^{-9} \mathrm{ACh} 0.5 \mathrm{cc}$ の拡張作用。
がある（第 7 図A）。この PVL 0.5cc の示す拡張作用の 強度は, 濃度 $10^{-9}$ の ACh 溶液0.5ccの現わす 拉張作用 のそれに匹敵する(第.8図)が，Adrenaline を濃度10-7 の割合に Ringer 液に加えて灌流を行った実験において は, PVL 0.5ccの現わす流出量の増加率は80〜120\%にも 達した。

しかるに，秋季の終り頃より冬季にかけて行った10 例の実験例についてみると，PVL 0.5cc の現わす拡張効 果は次第に衰え，軽度の拡張作用の後収縮効果を現わす 様になった（第 8図B）．この血管収縮作用は冬季への 移行と共に次第に強まり，拡張作用は益々弱まって，簃 冬季においては全く拡張が認められず，収縮效果のみが 現われる様になった，乙の季における20例についてみる と，約 $30 \%$ 減少率を示す収縮效果か $20 \mathrm{~m}$ 或いはそれ以 上持続するものが多い（第 7 図B及び第 8 図G）．それ にも拘らず，乙の時季において濃度 $10^{-9} \sim 10^{-10}$ のCh 溶液0.5ccを用うれば明らかに拡張作用が現われた。

ついで，春季になると再び初期の拡張作用が現われ 始め，同時に後期の収縮作用は次第に弱まって，初夏の候には再び顕著な拡張作用が認められ，収縮作用は殆ん ど消失した。 
b. 他の薬物亡の関係

80数例のガマを用いて，PVL と他の楽物との関係を検した。

i) Atropine に対する PVL と ACh の翣度

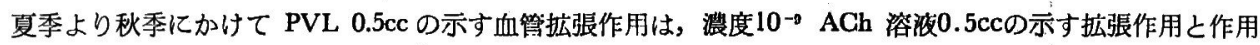

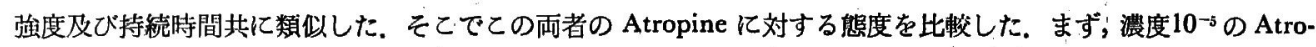

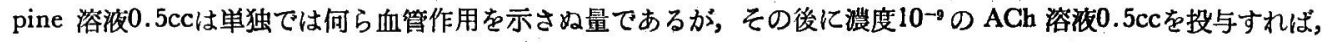
ACh の血管拡張作用を完全に抑制した. しかるに PVL 0.5ccの血管拡張作用は，この量の Atropine によって 何ら影響されることなく，無処置の埸合におけると同様に現われた。

ii） Benzylimidazoline に対する PVL と Adrenaline の龍度

秋季の終りより冬季にかけて，PVL が著明な収縮効果を現わす時季に Benzylimidazoline に対する態度を， Adrenaline の示す態度と比校した。 この時季における Adrenaline は㴽度 $10^{-8}$ 溶液 $0.5 \mathrm{cc} \sim 10^{-7}$ 溶液 $0.3 \mathrm{cc}$ で血 管拡張作用を現わし，濃度 $10^{-7}$ 溶液0.5cc以上では血管収縮作用を現わした，そして濃度 $10^{-6}$ 溶液0.5ccの示す血 管收縮作用の強度は，PVL 0.5ccの示す血管収縮作用にはづ匹敵した.

$0.2 \%$ Benzylimidazoline 溶液0.5ccを注入すれば，著明な血管拡張作用が現われるが，その作用の極盛期に 濃度 $10^{-6}$ の Adrenaline 溶液0.5ccを投与すると，Adrenaline の血管收縮作用は全く抑制されて現われない，し かるに, Adrenaline の代りに PVL 0.5ccを作用せしめると，依然として收縮作用が認められる.

次に投与順序を逆にして，PVL 0.5cc を投与して血管収縮の起っている時に，0.2\% Benzylimidazoline 溶 液0.5こcを投与すると，血管は拡張し，両者間には明ら かな相互拮抗関係が認められた. この梯な捛抗関係は罯 度 $10^{-3} \mathrm{BaCl}_{2}$ 溶液 $0.5 \mathrm{cc}$ と, $0.02 \%$ Benzylimidazoline 溶液 $0.5 \mathrm{c}$ の間にも認められた。

\section{2) 麻酔ガマ腸間膜血管に対する作用}

主として実験は秋季より冬季にかけ30数例のカ $j$ マを 用いて行った. PVL 0.5cc 投与により腸間膜血管も後肢 血管とはら゙同様の反応を示し，血管拡張作用と収縮作用 とが季節的に変動した。しかしながら腸間膜血管灌流実 験では，腸管の運動に基づく流出量の律動的変動が認め られることが多く，拡張より収縮への移行現象は，後肢 血管灌流実験における程明らかでなかった，また後肢血 管に対する PVL の主作用が拡張作用より収縮作用へ移

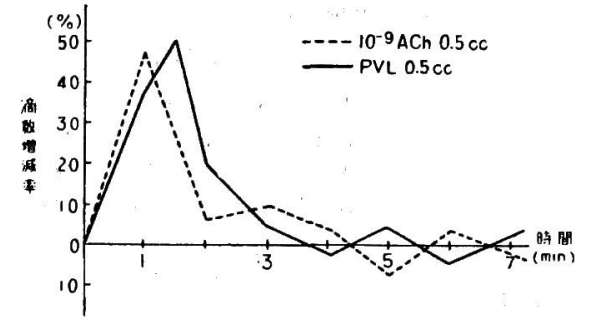

第9図. 麻酔ガマ腸間膜血管に対するPVL 及び ACh の作用比較. (秋季实臨)

— : PVL 0.5ccの拡張作用. …. : $10^{-9} \mathrm{ACh} 0.5 \mathrm{cc} の$ 拡張作用. 何れも滴数増娍率 (綎軸) に上る判定.

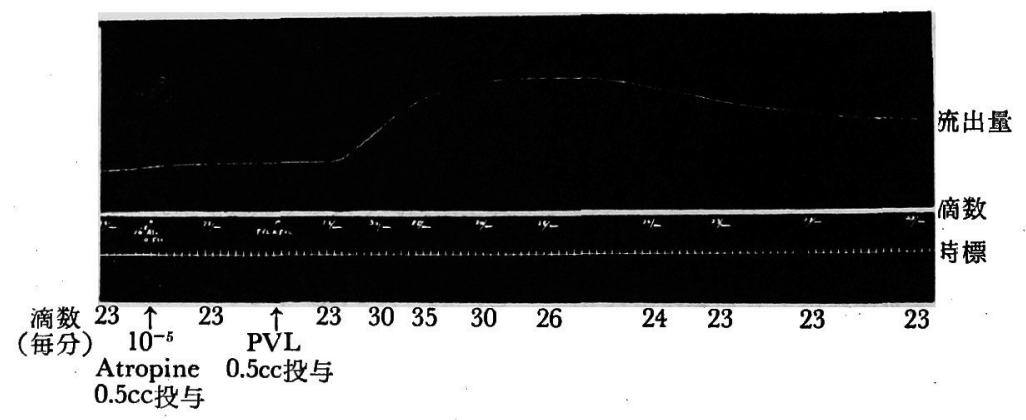

第10図. 麻醖ガ、腸間膜血管に扣ける PVLとAtropine との関係. $16 / \mathrm{XII}{ }^{\prime} 57,15^{\circ} \mathrm{C}, 200 \mathrm{~g}, \hat{\delta} ， 10 \%$ Urethane $3.5 \mathrm{cc} / 100 \mathrm{~g}$ 皮下注射，時標10s， 20 滴 $=0.95 \mathrm{cc}$, 圧 : $20 \mathrm{~cm}$ 水柱, 薬物投与順, $10^{-5}$ Atropine $0.5 \mathrm{cc}$, PVL $0.5 \mathrm{cc}$, 曲線の上昇は滴数增加, 血管拡張を示す。 
行し，或いは收縮作用のみ現われ始める特期，すなわち12月下旬において屯，腸問膜血管では殆んど拉張作用の みが疑繁され，明らかな収縮作用を認める様になるのはさらに冬季の深まる頃であり，従って两血管系統の反心

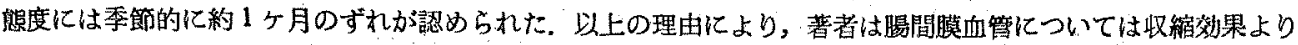

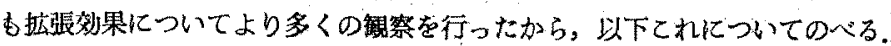

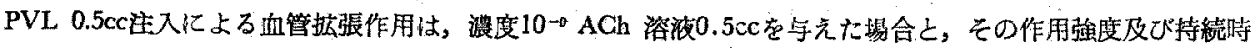

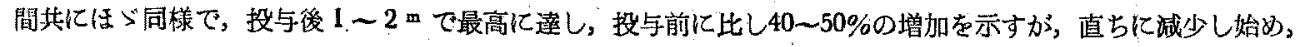
投与後朽よを $3 \mathrm{~m}$ 経過して旧に復した（第 9 図).

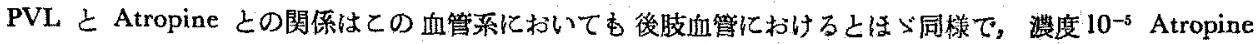

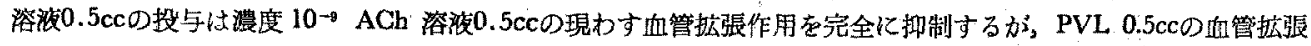
作用は Atropine 前処澄に同の拘りるなく発現した（第10园).

3.小括

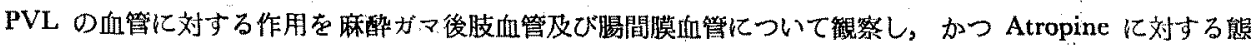

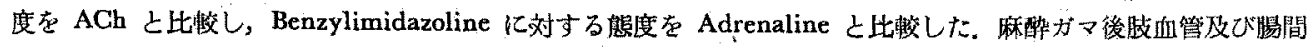

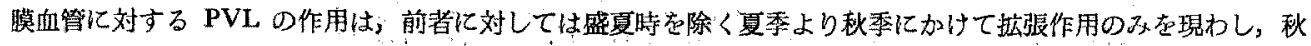
季の終り頃より冬季にかけては航張につぐ収縮を現わし，冬末季には収縮作用もはづこれと同梯であったが，前

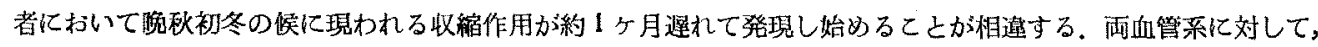
PVL が血管捄張作用を示す時期に，その Atropine に対する態度を ACh のをれと比較すると，AChの示す㮩 管拡張作用が Atropine Kよって全く狮制されるのに反，PVL の作用は Atropine に影響されることなく発

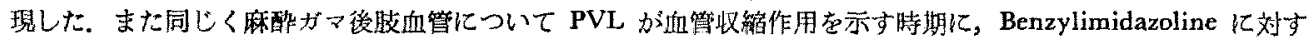
る態度を Adrenaline のそれと比校したが，Benzylimidazoline とよって Adrenaline の作用が全く抑制される

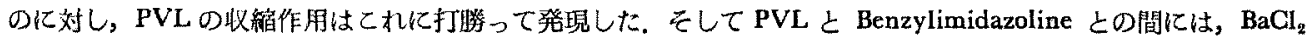
と Benzylimidazoline 間の相互拮抗現象之同粎の関䋆か認められた。

\section{IV. 腸管に対する作用}

\section{1. 実験動物及ひ実験方法}

\section{1) 生体内關管に関する実験法}

体重 2〜3 kg のウサギ及び体重 $3 \mathrm{~kg}$ 前後のネコを眡い, Trendelenburg 法に集して実験を行った。 たくし，

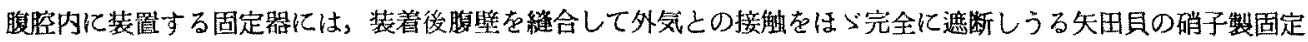

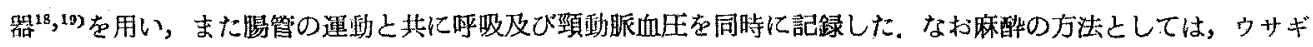
には $10 \%$ Urethane 溶液を 1 - $1.5 \mathrm{~g} / \mathrm{kg}$ の㓶合で皮下に，ネコには $1.5 \%$ Pentobarbitalum sodicum 溶液を30 $\mathrm{mg} / \mathrm{kg}$ の割合で腹腔内に夫々注射した，PVL の注射はウサギにおいては耳静脈内に，ネコにおいては股静眽内 そ施した.

\section{2) 摘出腸管に関する実験法}

体重 2〜3 kg のウサギ及び 体重200〜300gのモルモットを用い，放血致死後回腸をとの終端より 5 〜 $10 \mathrm{~cm}$

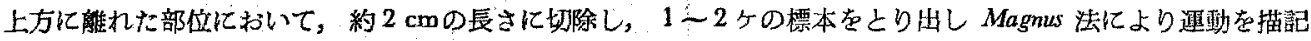
せしめた.Magnus 管内の Tyrode 液量は10cc，pHは7.4亡し一側より絶光ず空気を送入した。䔞液投与の漈に

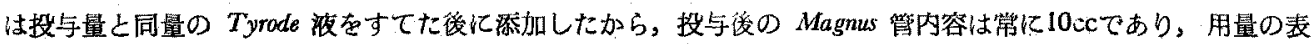
記には管内における薬物の最終濃度を以てした。

\section{2. 実験成維}

1）门サギ及びネコ生体内腸管に対する作用

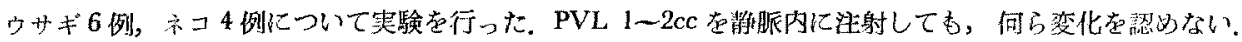

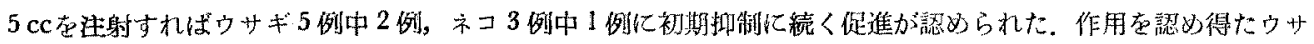
ギの1例について述心れば，注射末期より晹管の緊張は軽度に下降し，邆動むまた一部抑制されるが，全く停止

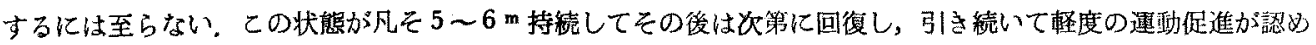




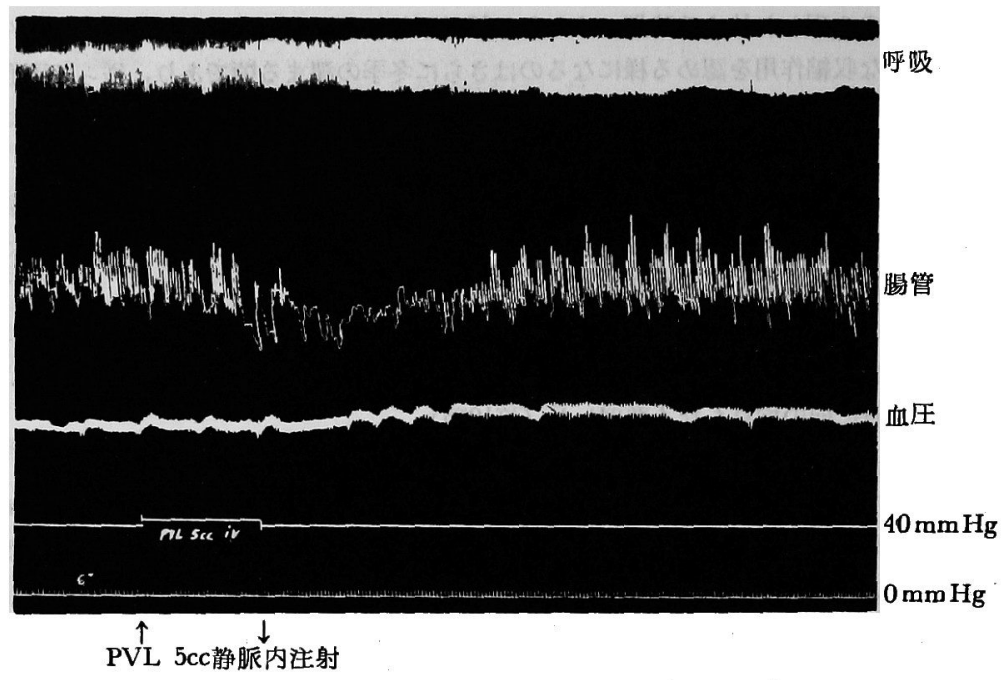

第11图，ウサギ生体内腸管に対する PVL の作用.

$31 / \mathrm{X}{ }^{\prime} 57,19^{\circ} \mathrm{C}, 2.6 \mathrm{~kg} ， \hat{s} ， 10 \%$ Urethane $1 \mathrm{~g} / \mathrm{kg}$ 皮下注射， 時標 6 `, PVL $5 \mathrm{cc}$ 静脈内注射.

られて約10m持統した後ほづ旧に復した（第11図）.

2) 摘出腸管に対する作用

a. ウサギ摘出腸管

ウサギ摘出腸管16例につき PVL $0.5 \mathrm{cc}, 1$ cc及び 2 ccを投与してその作用を観察した. を の結果，0.5 ecまたは $1 \mathrm{cc}$ 用いた例に 3 例の 然作用例を数えたが，しかし，1 ccを中心代 記 3 種の用量に跨って典型的作用型亡思われる むの7例な見たから以下これについて記述す る.すなわち，PVL 投与直後一過性に振巾の 縮小をきたすが，間むなく逆に軽度ながら振巾 の增大に変るのである，代表例として第12図に PVL 1cct作用せしめた1例を揭げた，2ccを 作用せしめてむ，これと同様の作用を見る場合 ああるが，多くは作用直後の運動抑制が現われ ないで，最初より緊張上昇し，これについで振 巾の増大がみられた。

\section{b、モルモット摘出腸管}

モルモットの腸管はウサギの腸管に比し, 運禹の振门狭く毉張の昇降が見易いために，種 々の桨物の作用が読取り易い利点を有すること 〉，小量の PVL に反応するという利点をも有 しているので，著者はてれについて10列の実験 を試み，PVLは0.2〜 1 ccを投与した，何れの 実験例においても PVL の作用は腸管に対して

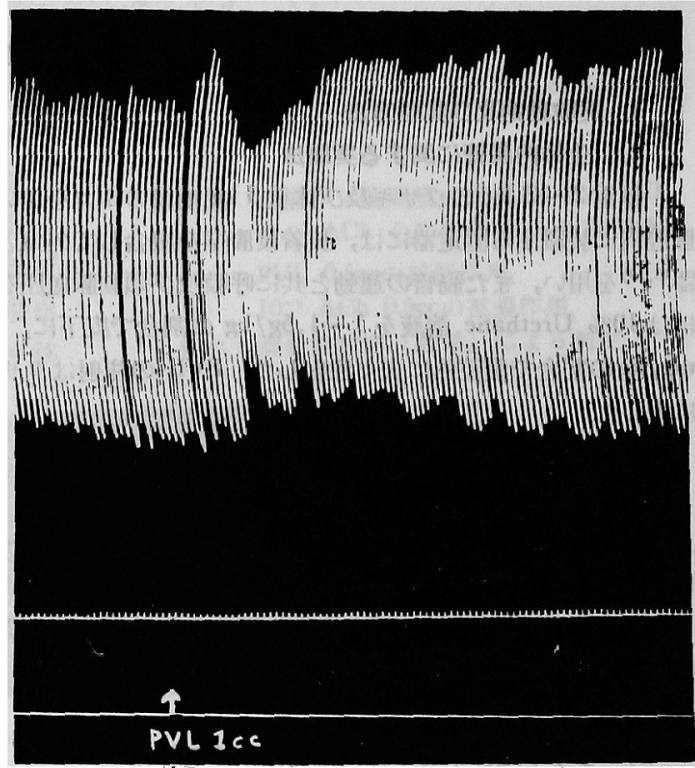

PVL $1 \mathrm{cc}$ 投与

第12図，ウサギ摘出腸管に対する PVL の作用 (Magnus 法)

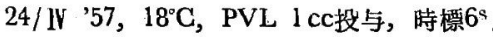


促進的であり，0.2 cこを投与した 1 例において あかなり著明な㬎張上昇を見たが，しかし著者 は一定したより明膫な作用例を得るために，他 の9例には0.5〜 $1 \mathrm{cc}$ 用いた. その結果は何 れすはら同様であるから，こ〉では $0.5 \mathrm{cc}$ を投 与した 1 例を代表例として述べる。すなわち， PVL 投与直後晹管は急激に収縮して 緊張上昇 し，約 $1 \mathrm{~m}$ 間持続した後徐々に弛緩するが，な お正常時以上の高い緊張を維持し，乙れに律動 性運動か現われてくる. 収縮回数は対照時より や〉多いが，5〜6m後にはら゙旧に復し，祭張 あ約 $7 \mathrm{~m}$ 後には旧に復した (第13図). なお投 与直後の収縮には，これに先き立って数秒間の

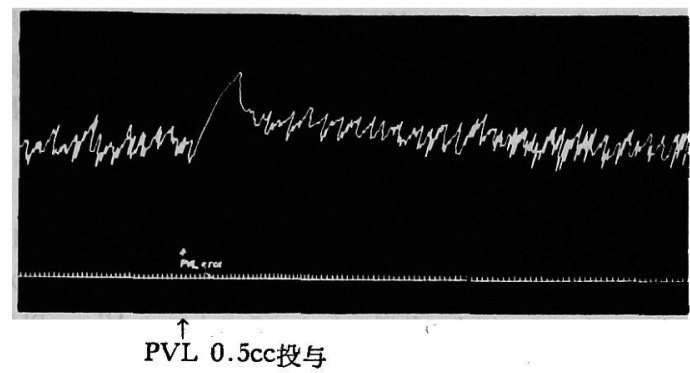

第13図，モルモット摘出腸管に対する PVLの作用 (Magnus 法).

$18 / \mathrm{XII} 57,17^{\circ} \mathrm{C}$ ，管内液量 $10 \mathrm{cc}$ ，時標 $6^{\prime}$ ， PVL 0.5 cc投与.

祭張下降を見るととが多く，変動は基本的にはウサギの場合と共通した性烙のあのであることがうからわれた。

\section{c. 他の薬物之の関係}

ウサギ 8 例，モルモット16例の摘出腸管を用い，PVL と他の茎物との作用関係を検索した. その絬果，両 種の腸管はほ ら゙同様な成績を示したので，以下モルモット摘法腸管についてのべる。

i) Atropine に対する PVL とACh の態度

ACh は濃度 $10^{-1 n}$ 以下では 作用を現わさな いが, $10^{-9}$ の輍度では緊張上昇をさたし，10 〜 10-8 の濃度にわいてほ による効果に匹敵する堅張上昇を示す. ACh 投 与によって起った緊張上昇が極期に達した時に PVE 在投与すれば，さらに緊張は上昇して二 相性の収縮が得られる。

Atropine は 10`て の濃度で腸筧の 緊張を低 下せしめ，かつ運動を抑制する。 この濃度の Atropine り以て前処置すれば，濃度 $10^{-9}$ の ACh の作用は著しく抑制されるのであるが， PVL 0.5cc の作用は全く影響をうけず，無処犆 の場合にわけると同程度の収縮効果が認められ た（第14図A）。しか子 PVL 投与後に再度 $10^{-7}$ の Atropine を作用せしめても，その現わすへ き堅張下降作用は認められない.

次に投与順序を逆にして PVL 0.5－1ccの 投与によって緊張の上昇した時期に，濃度 $10^{-7}$ 〜10-8の Atropine を作用せしめても緊張低下 は認め難く，濃度 $10^{-5}$ を用いて初めて緊張下降 を示した：そしてその後に再度 PVL Icc を投 与してむ，その作用は完全に抑制されて現われ なかった(第14図B).

ii) Adrenaline 及び $\mathrm{MgSO}_{4}$ との関係 モルモット摘出腸管に対し， Adrenaline は睑度 $10^{-8}$ で緊張を 下降せしめ 運動を 抑制す
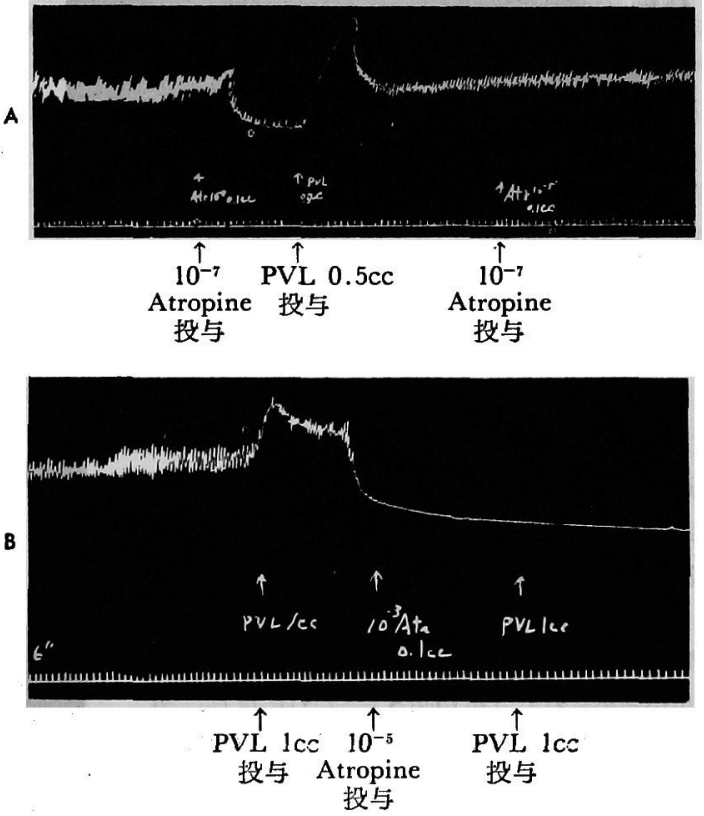

第14図、モルモット摘出腸管に打ける PVL と Atropine との怙抗 (Magnus 法).

管内液量 $10 \mathrm{cc}$, 時標 6 "

A : $24 /$ \ $57,15^{\circ} \mathrm{G}$, 薬物投与順, $10^{-7}$ Atropine, PVL $0.5 \mathrm{cc}, 10^{-7}$ Atropine.

B : $21 /$ XII ' $57,16^{\circ} \mathrm{C}$, 薬物投与順, PVL lcc, $10^{-5}$ Atropine, PVL 1cc. 
る. 濃度 $1 \times 10^{-8} \sim 5 \times 10^{-8}$ の Adrenaline の緊張下降作用は, PVL lccによって怙抗された. しかし濃度を高

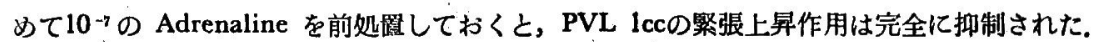

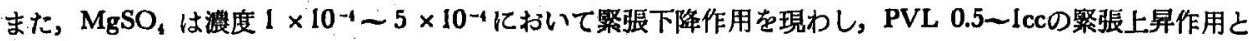
相互に拮抗した.

\section{d. 透析 PVL の作用}

PVL の作用は先に述べた Langendorf-Gunn 法立びに田村・小林法による摘出心臟実験成績及び 摘出晹管実 験成績において見ら机た加く，外見上相反する様相のものが相次で起り，その多様複雑性を思わせた。 そして PVL 自体は単一組成の物質でなく，その中には Virus 以外にも多種類の物質が混在していることも明らかなこ とであるから，その中に薬理作用を現わす有效物質が何種類か含まれているならば，これが作用の複雑性の原因 となり得る訳である．乙の镜点から著者はセロフォン膜を以て PVL の透析を行い，乙れを内外両成分に分離し たすのについて作用の相違の有無を調へてみることを思い立った. 実験方法としてはウサギ摘出腸管 Magnus 法 によること〉した，透析は既述の如く行い，外液については数回透析膜外液を取りかえ，最終的にこれらを集み，

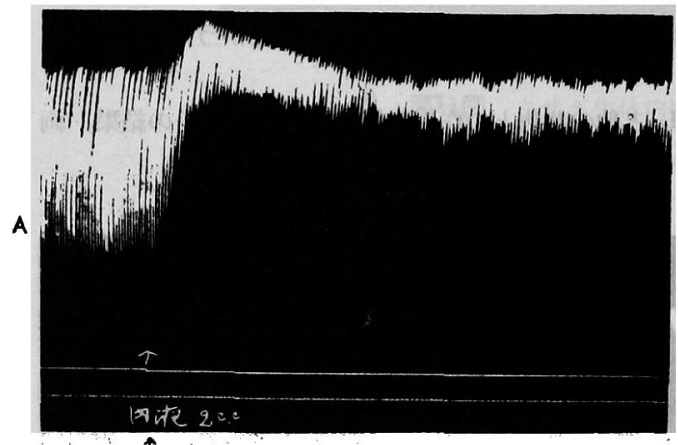

内泼 2 c c投与

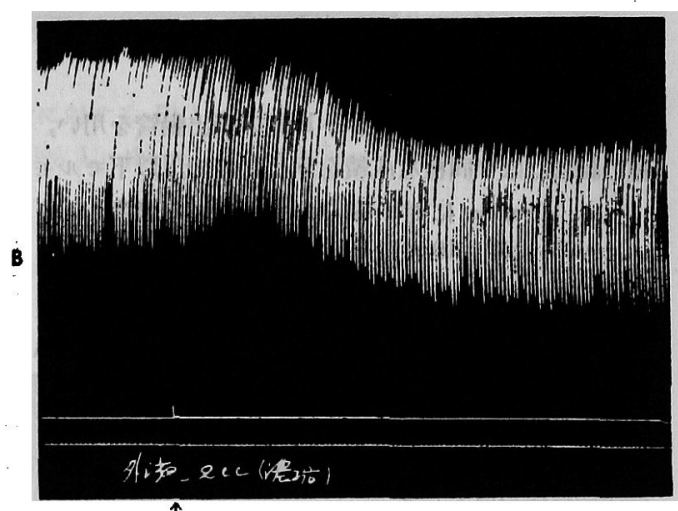

外液 2 cc投与

第15図. ウサギ摘出腸管に対する PVL 透析内液及び外液の作用 (Magnus 法).

$17 / \mathrm{XI}$ '56, 管内液量 $10 \mathrm{cc}$, 時標 $6^{\star}$ 。 A : 内液 $2 \mathrm{cc}$ 投与，B：外液 $2 \mathrm{cc}$ 投与.

透析開始時にわける PVLの量になるまで減圧 弥溜を行って補正した後使用した. 実験成績は 次の通りである.

まず内液 2 ccを投与すれば直後より著明な 緊張上昇と振巾縮小が現われ，運動促進的な作 用が認められた（第15図A）。乙れに反し，外 液 2 ccを投与した実験例においては，まず振门 の縮小か現われ，徐々に，しかし著明に唋張は 下降して運動抑制的な作用が認められた（第15 図B ).

先に記述したウサギ摘出腸管に対するPVL の作用は，恰もこの内液 - 外液の個々の作用が 重畳したものに相当し，その際用量または藏器 反応性の違いによって，或る場合にはてれが現 われることなく直ちに緊張上昇が現われるもの

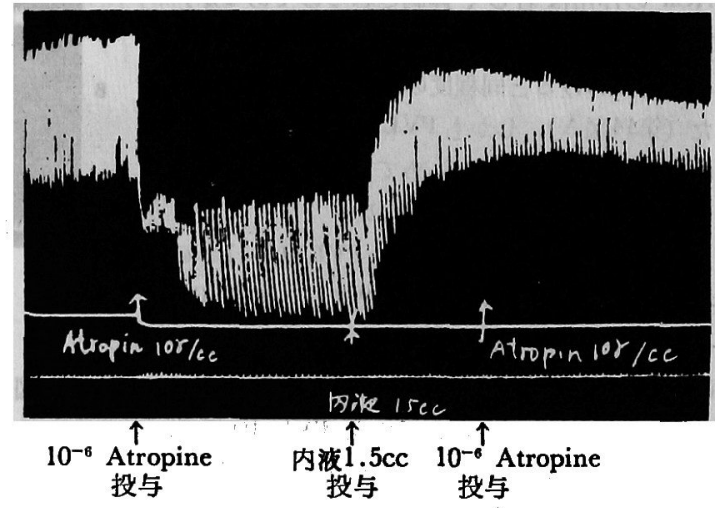

第16图。ウサギ摘出腸管に招ける PVL 透析内液と Atropine との拮抗 (Magmes 法).

17 / XI '56, 管内液量 $10 \mathrm{cc}$, 時標6s. 薬物投与順: $10^{-6}$ Atropine, 内液 $1.5 \mathrm{cc}, 10^{-6}$ Atropine. 
と解してよかわうと思われる。

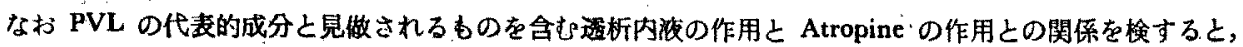

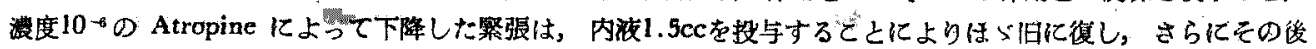

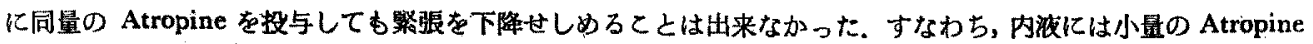
の作用に捛抗し，乙扎打腾つ作用があるのてある(第16図).

3.小，括

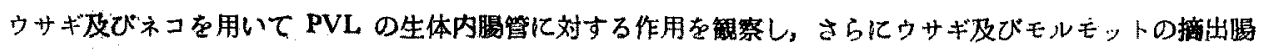
管を用いて PVL の作用を検し，かつAtropine に対する作用態度を ACh のそれ亡比校し，また Adrenaline 及び $\mathrm{MgSO}_{4}$ との作用関係を検索した。.

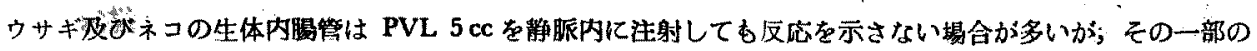

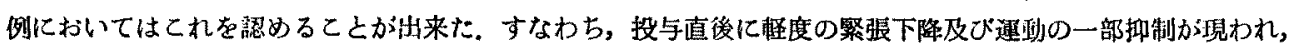
整らくして緊張も運動す正常に回復, 或いはさらに样度の運動促進が起るのが認められた.

摘出腸管にわいては，ウサギの堨合投与直後に短時間の振门縮小が現かれるが，間すなく軽度ながら逆に増

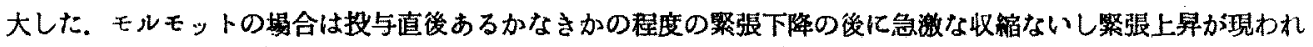

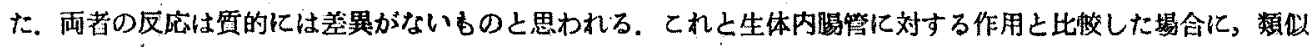

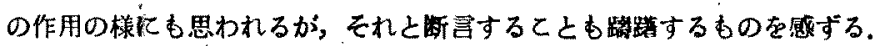

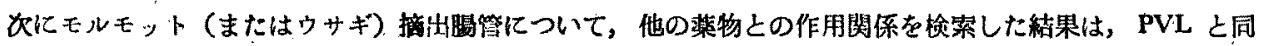

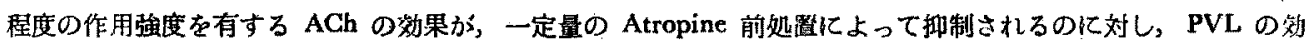

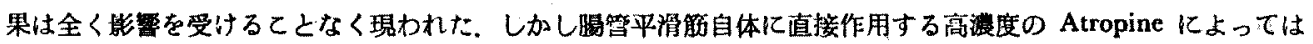
PVL の作用は拮抗され，その前処稳によって PVL の作用は消失した. さらに Adrenaline 及び MgSOの倩

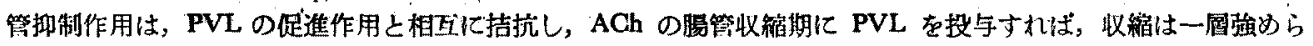
れて二相性の収縇を現わした。

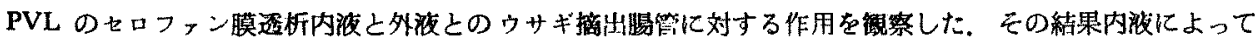
は著明な緊張上昇が起るのに対し，外液によっては反対に一過性の振门縮小の後に著明な緊張下降が起るこよを

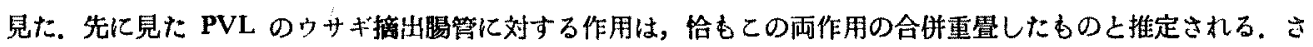

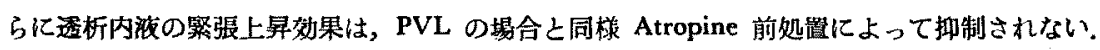

\section{V. 子宮に対する作用}

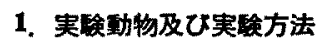

1）生体内子宮に関する実験法

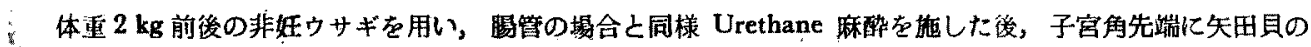

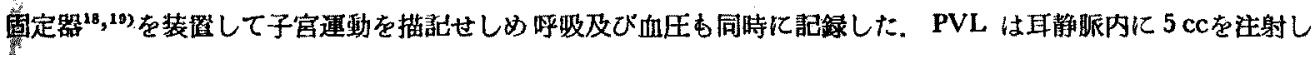
t.

\section{2）摘出子宮に阙する実駼法}

体重 $2 \mathrm{~kg}$ 前後の非妊ウサギ及び体重100－200gの非妊テットを用い，放血致死後左右車子宫角先端部より約

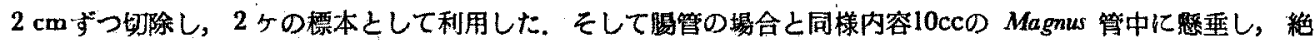

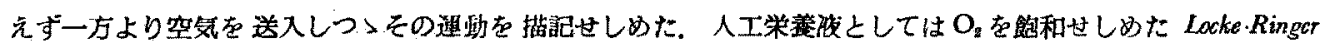

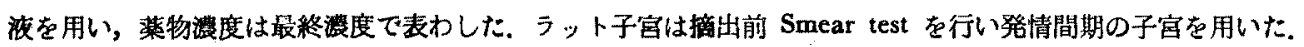

\section{2. 実稳成统}

1）ウサギ生体内子宮に対する作用

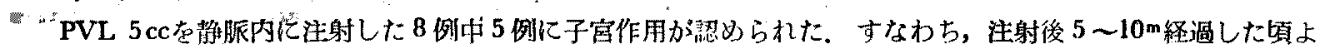

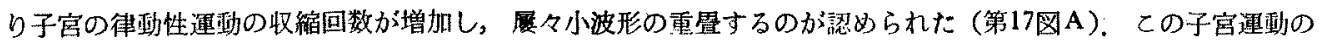

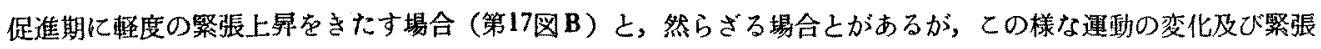
の上昇は10〜20m持続した後はぐ元に厌った。 


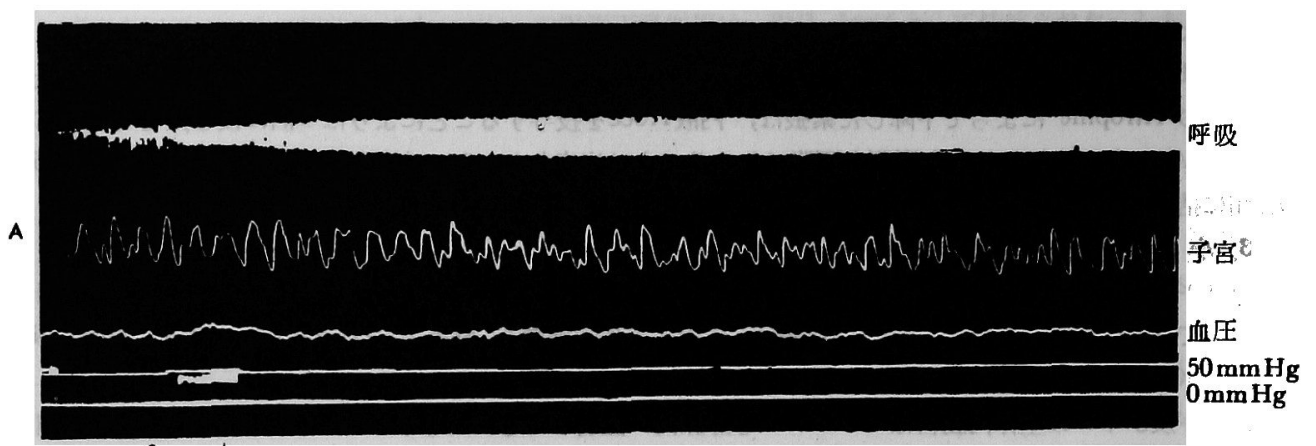

PVL $5 \mathrm{cc}$ 静眽内注射

B

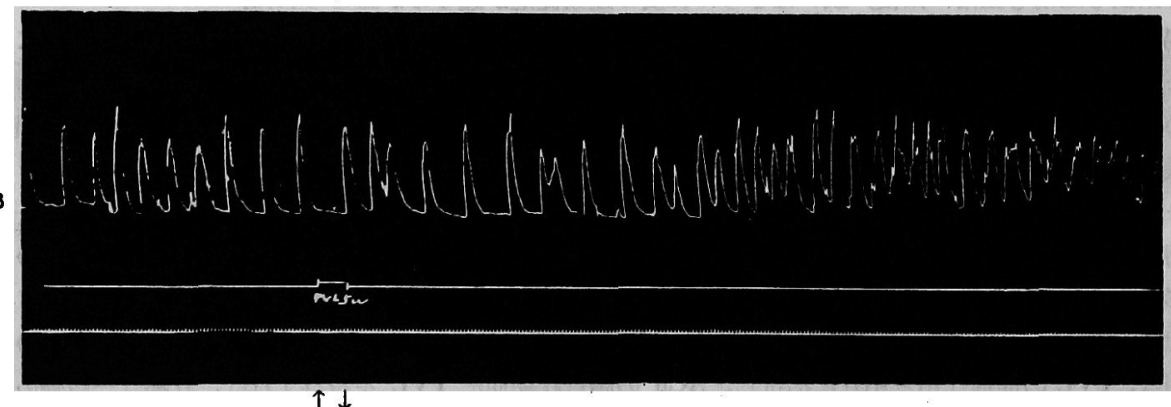

PVL $5 \mathrm{cc}$ 静脈内注射

第17図. ウサギ生体内子宮運動に対する PVL の作用.

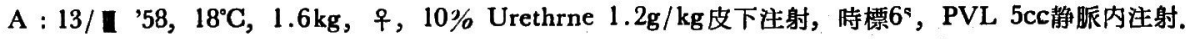

B : 3/ I ' $58,14^{\circ} \mathrm{C}, 1.9 \mathrm{~kg}$, 우, $10 \%$ Urcthane $1 \mathrm{~g} / \mathrm{kg}$ 皮下注射, 時標6`，PVL $5 \mathrm{cc}$ 静脈内注射.

\section{2) 摘出子宮に対する作用}

ウサギ10例，ラット20例について実験を行った。 ウサギ摘出子官は PVL に対して顕著に反応した。すすな ち，PVL lccを用いた多数の例において，投与直後より収縮運動の周期が著しく短縮するのが認められた．この 際，個々の収縮波に高低のあるこ とは正常時と同様であるが，収縮 高の高いもの>うちには, 正常波 に比して大きいものも間々現われ る. これらの変化は $8 \sim 10^{\mathrm{m}}$ 持続 してはら゙旧に復した(第18図). 小数例においては，正常時におい て子宮の緊張に周期的高低を示す あのがあり，かような標本にわい てはこの運動促進期に, 緊張性収 縮と緊張の上昇とが見られた。

発情間期にあるラット子宮に 対しても PVL の運動促進作用は 認められ，PVL lccを投与すれば 収縮高の増大之収縮運動の周期の

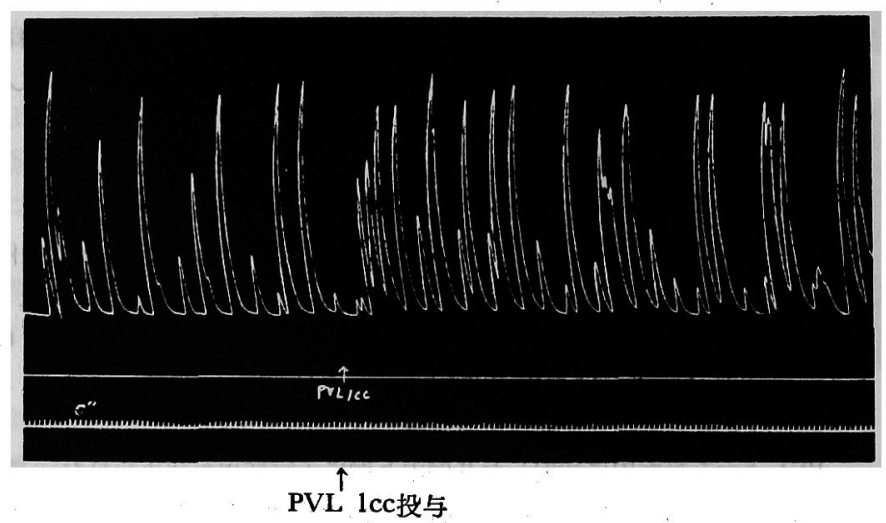

第18図，ウサギ摘出子宮に対する PVL の作用 (Magnus 法). $24 /$ I ' $58,17^{\circ} \mathrm{C}$ ，管内液量 $10 \mathrm{cc}$ ，時標 $6^{\mathrm{s}}$, PVL $1 \mathrm{cc}$ 投与. 
短縮が起った。

3）他の策物との関係

ウサギ 6 例，ラ.ット10例の子宮について PVL と他の禁物との関係を 検索した. ACh は両子宮に対して PVL と同様運动促進的に作用する. Adrenaline はウサギ子宮に対しては運怔促進的に働くが，ラット子宮に対 しては運動抑制的に働き，PVL と逆の作用を現わす. 従ってウサ ギ子宮については, Benzylimidazoline に対する Adrenaline との 作用驡度亚びに $\mathrm{MgSO}_{4}$ との関係 を検し，ラット子宮については Atropine に対する ACh との作 用態度の比較を行った. その理由 はウサギ子宮におけるよりあ Atropine に対する ACh 及び.PVL の作用比校が容易であったととに よる.

\section{a. ウサギ摘出子宮}

Adrenaline はウサギ摘出子 宮に対して，濃度10-テにおいて著 明な緊張上昇を示した。これは 10-7 -10-6 の濃度の ACh の緊張 上昇作用及び PVL の作用之同一 方向の作用である。 との Adrenaline の緊張上昇期に PVL を投 与してむ，PVL の緊張上昇期に Adrenaline を投与しても，さら に緊張は上昇して二相性の波型が 得られる。

Benzylimidazoline は濃度 10-5において著明な緊張上昇を現 たす.この緊張上昇期に PVL 1 ccを投与すると，一過性緊張下 降をきたすが，直ちに投与時に上 趈る緊張上昇を現わした(第19図)。 さらにその後において, 単独投与 では祭張上昇を現わす濃度 $10^{-7}$ の Adrenaline（第19図左）を投与す れば，緊張は下降した。すすなわち， Benzylimidazoline 亿よって Adrenaline の作用は反転するが, PVLの作用は影響をうけることな く現われる. 従って PVL と Adrenaline とは同一方向の作 用を有するが，その作用機序は明

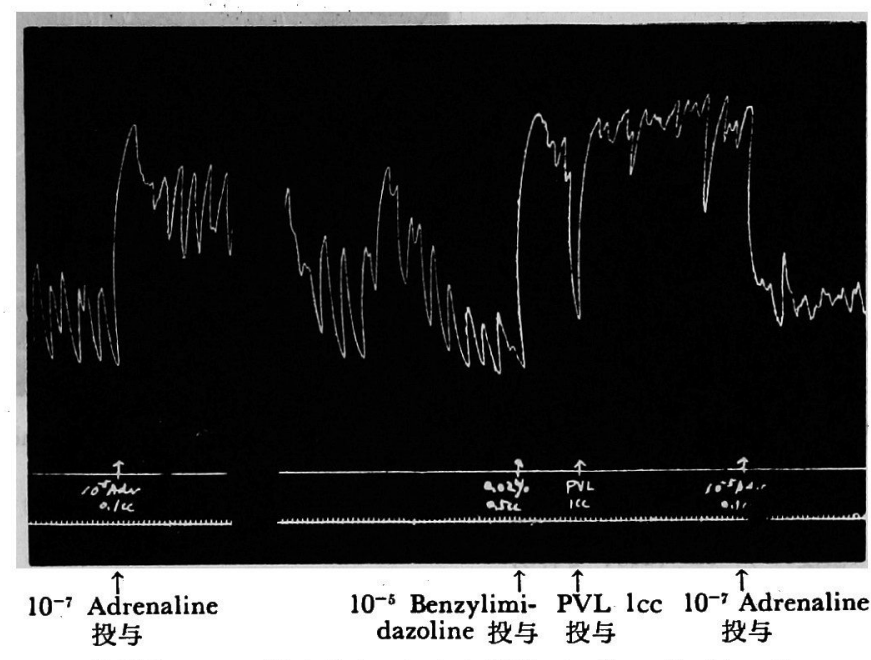

第19図. ウサギ摘出子宮に扰ける PVL と Benzylimidazoline との関係 (Magnus 法).

$24 /$ I $58,17^{\circ} \mathrm{C}$, 管内液量 $10 \mathrm{cc}$, 時標 $6^{a}$. 薬物投与順, 左 : $10^{-7}$ Adrenaline.

右 : $10^{-5}$ Benzylimidazoline, PVL 1cc, $10^{-7}$ Adrenaline.

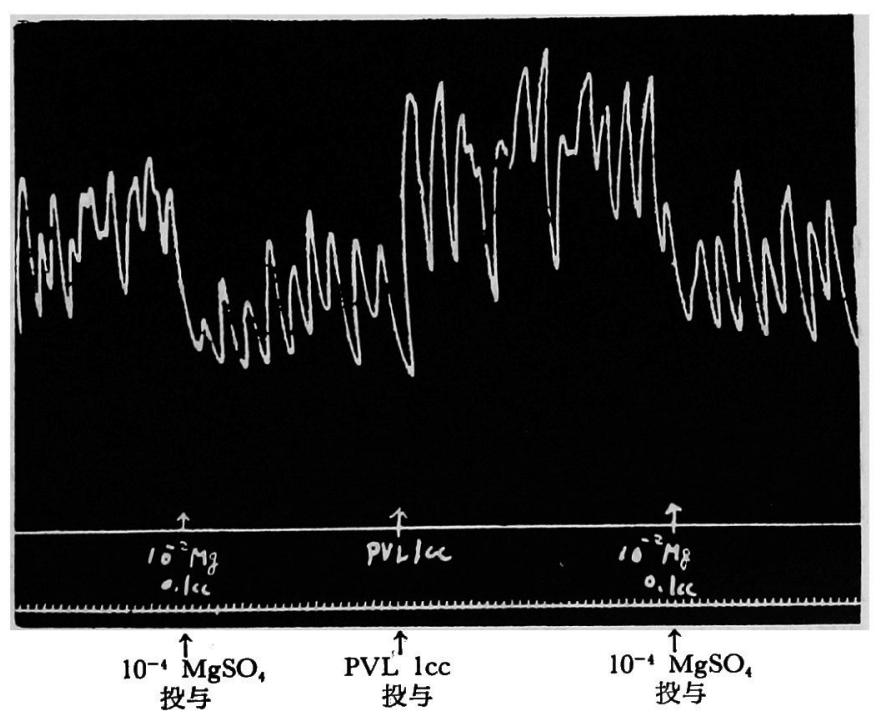

第20図. ウサギ摘出子宮における PVL と $\mathrm{MgSO}_{4}$ との拮抗. $24 /$ 】 $58,17^{\circ} \mathrm{C}$, 管内液量 $10 \mathrm{cc}$, 時標 $6^{\circ}$. 薬物投与順, $10^{-4} \mathrm{MgSO}_{4}$, PVL lcc, $10^{-4} \mathrm{MgSO}_{4}$. 
らかに相違する。

次保 $\mathrm{MgSO}_{4}$ 汇対する $\mathrm{BaCl}_{2}$ と PVL の作用を比校した，溜

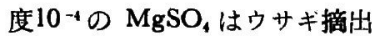
子宮に対して常に緊張を下降せ しめ, こ尚下降期に PVL 1 cc を投与すれば緊張は回復するの みからら上昇を示した：その 後， $\mathrm{MgSO}_{4}$ を投与すれば緊張 は下降して対照時以下となり， 両者は相互、楛抗した(第20図)。 さらに，同澧度の $\mathrm{MgSO}_{4}$ は PVL 亿対する之同様, 湌度 $10^{-5}$ の $\mathrm{BaCl}_{2}$ 及漕度 $10^{-7}$ の Adrenaline 上も相互に拮抗した。

\section{b. ラッ卜摘出子宮}

ラット摘出子宮に対しACh

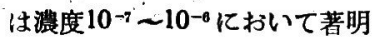
な緊張上昇を示す。濃度 $2 \times$ 10-6 の Atropine は濃度 $2 \times$

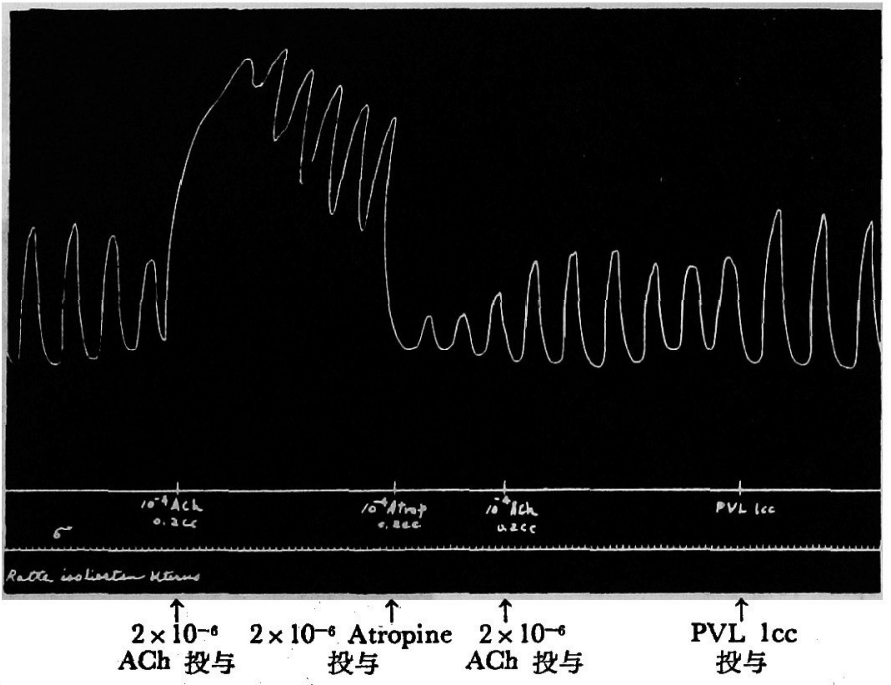

第21图。ラット摘出子官に扰ける PVL と Atropine との拮抗 (Magnus 法).

$10 /$ 【 $58,17^{\circ} \mathrm{C}$, 管内液量 $10 \mathrm{cc}$ ，時標 $6^{n}$ 。

薬物投与順, $2 \times 10^{-6} \mathrm{ACh}, 2 \times 10^{-6}$ Atropine, $2 \times 10^{-6} \mathrm{ACh}$, PVL lcc.

10-6の ACh 亿よって上昇した緊張を低下せしめ，同時に収縮高をむ縮小せしめる，その後前と同浱度の ACh を作用せしめても，てれを㱠んど完全に近く抑制し，緊㖘上昇は起らない，収縮高も正常以下であった。しかし， PVL lccを作用せしめると，単独作用時と同様，収縮高の対照時以上の増大をきたした（第21図）.

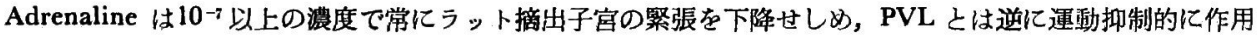
した.

3. 小 括

PVL の子宮に対する作用を，ウサギ生体内子宮と，ウサギ及びラットの摘出子宮とについて観察し，さら にウサギ摘出子宮について Benzylimidazoline に対する Adrenaline どの比䡆並びに $\mathrm{MgSO}_{4}$ との関係を検索 し，ラット摘出子宮については Atropine に対する作用䅧度を ACh のそれと比較した。

ウサギ生体内子宮に対しては，注射後 $5 \mathrm{~m}$. 以上経過した後律動性収縮運動の回数增加と，時にはそれと共に 僅かに緊張の上昇をきたし，ての状熊が10m以上持続した。

ウサギ及びラット摘出子官は共に PVL によって収縮回数の增加を現わし，前者にわいては時に緊張上昇を 伴なう例も認めた。. Adrenaline はウサギ子宫に対して緊張を上昇せしめて PVL 之同一方向作用した. しか し，両者の Benzylimidazoline に対する態度の比較実験において，PVL の緊張上昇効果は Benzylimidazoline によって反転されないのに対し，Adrenaline のそれは反転されて繁張下降を示し，両者の作用機序は明らかに 相違することが証明せられた。ラット子官は Adrenaline によって繁張が下降するから，PVL の作用との相違 が最も簡単に知られた．ACh はウサギ及びラット摘出子宫に対し，PVL と同様に運動促進的に作用したが，作 用の観察の容易なラット摘出子宫を用いて，Atropine 亿対するPVL とACh との作用態度を比較した結果， ACh の作用は Atropine 前処置によって著しく抑制されるのに対し，PVL の運動促進作用は Atropine 之は無 関倸に現われた。ささらに PVL はウサギ摘出子官において， $\mathrm{MgSO}_{4}$ の緊張下降作用之相互に拮抗した。

\section{VI. 気管及び文管支に対する作用}

1. 実殹勤物及ひ実験方法

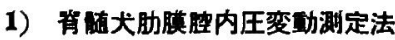




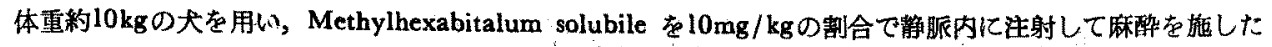

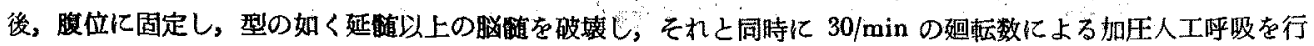

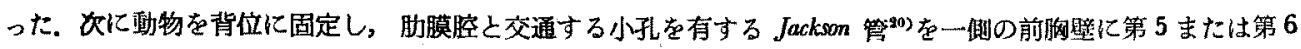

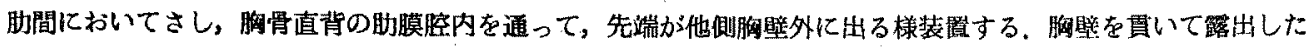
先端部には，貫通用の金具が装置してあるから，てれをはずしてゴム筫を取着け，スクリュ一コックにより空気

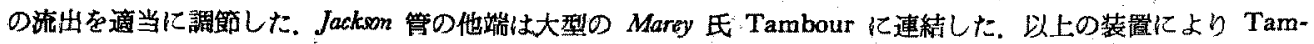

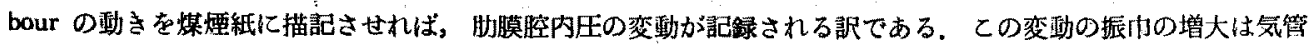

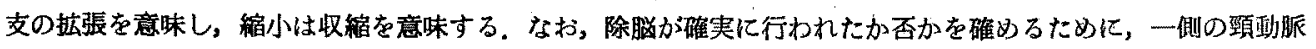
より血仕を描記せしめ，実験開始前短時間人工呼吸器を停止して，一㭙的に Anoxie の状熊を起させ，て扎によ

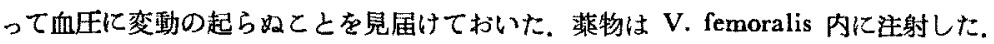

\section{2）摘出気管及び気管支に䦦する実駼法}

\section{。.モルモット及びウサギ摘出気管}

体重200〜300gのモルモット及び体重 2ー3 kgのウサギを用い，放血致死せしめた後直ちに気管を摘出し，

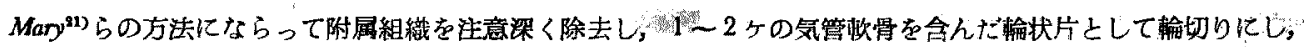

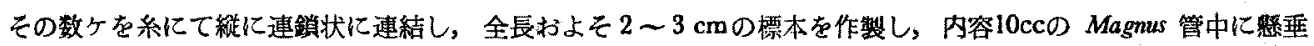

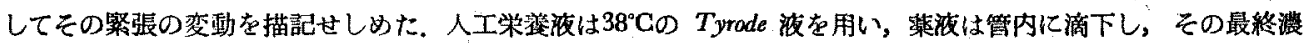
度を記載した。

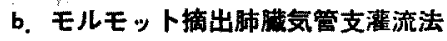

モルモットの肺藏を気管と共に摘出し，肺に孔を穿ち，気管より人工策盖洨を流入せしめて，肺の孔より流

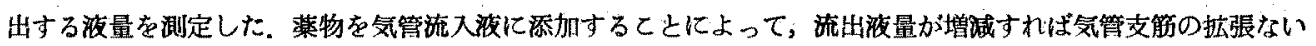
し収縮を意味するすのとする，実験方法は原理的には Warnant の万法 ${ }^{29)}$ と同じであるが，一部改变した。

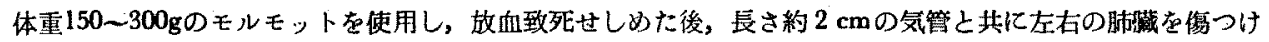

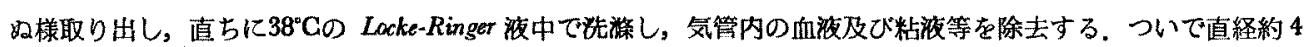

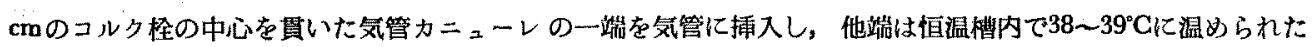

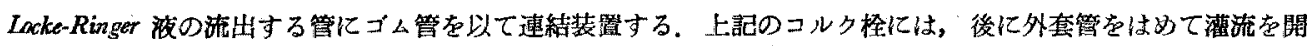

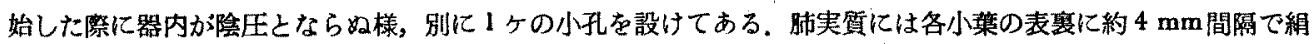
針を以て小孔を穿ち，気管より流入する灌流激が外部に流出しうる様にした，以上の操作によって作製装置した 標本に全長約 $8 \mathrm{~cm}$ ，直徍約 $4 \mathrm{~cm}$ の硝子製冈筒型外套管をかぶせ，気管カニューレをさしたコルク柽にはめ込め

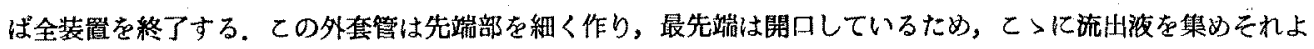

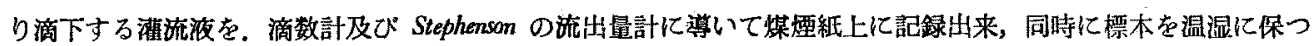

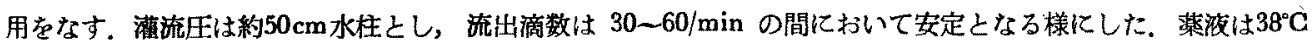
に加温したものを気管カニューレ直上のゴム管内に徐々に注入した，実験成績として気管支の拡張或いは収縮の

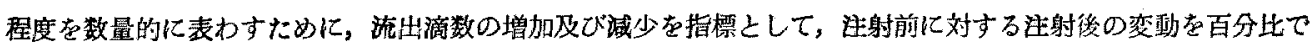

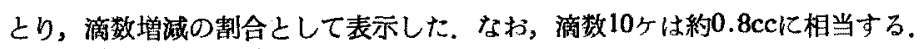

\section{2. 実験成辕}

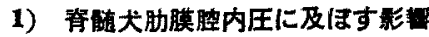

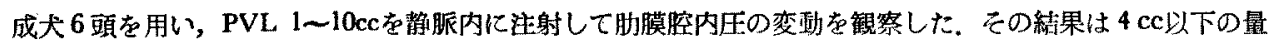
では影響を認めず，5〜10ccの大量を用いた実験例 4 例中 2 例に，極めて僅微な振巾の堌大が認められ，30mの 籍察時間終了まて持続した(第22図).

2）摘出気管及ひ気管支に対する作用

。.モルモット及ひウサギ摘出気管

モルモット8匹，ウサギ3匹の摘出気管を用い，PVL 各1 ccを投与しその作用を観察した。 モルモット気 管における2 例老除いて他は全く作用が認められなかった，乙の PVLに不応のモルモット気管筋は, Histamine

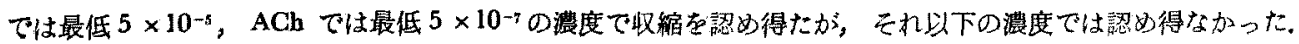




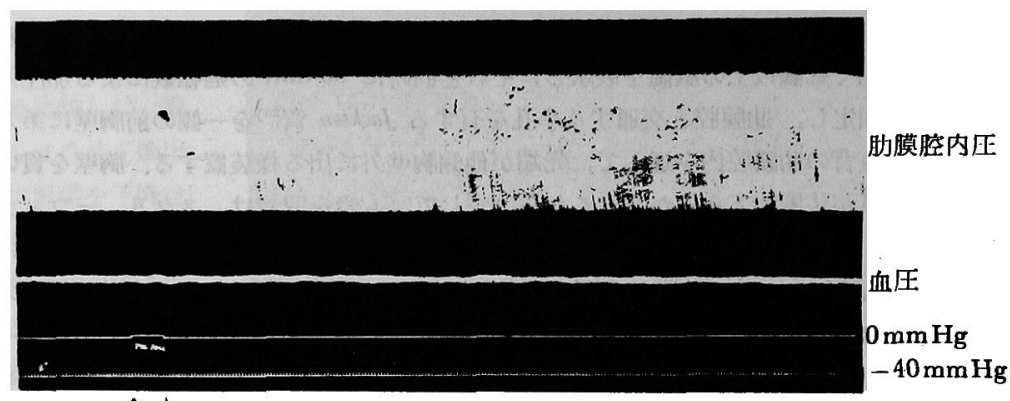

$\uparrow \downarrow$

PVL 10:c静脈内注射

第22図. 脊榷犬胁膜腔内圧に及ぼす PVL の影響。

$6 / x \| 57,16^{\circ} \mathrm{C}, 8 \mathrm{~kg}$, 古, 時標 $6^{\circ}$, PVL $10 \mathrm{cc}$ 静脈内注射.

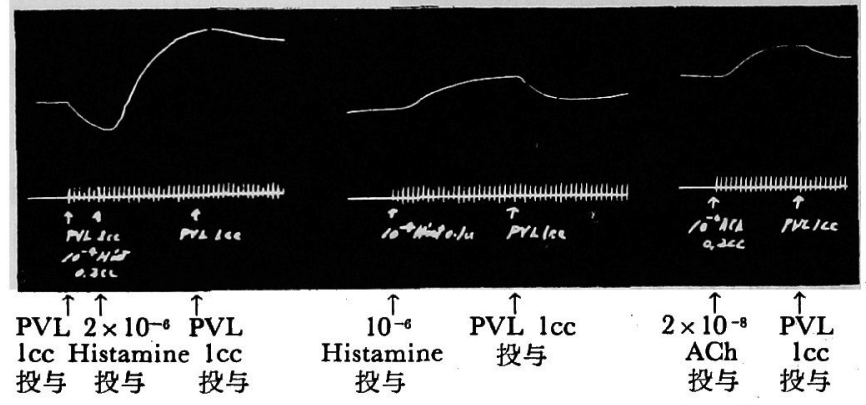

第23図.モルモツト摘出気管に扣ける PVLと Histamine 及び ACh との拮抗。

$22 / \mathbb{X} 57 ， 22^{\circ} \mathrm{C}$ ，管内液量 $10 \mathrm{cc}$ ，時標 $20^{`}$.

薬物投与順, 左 : PVL lcc, $2 \times 10^{-6}$ Histamine, PVL lcc. 中: $10^{-6}$ Histamine, PVL 1cc. 右 : $2 \times 10^{-8}$ ACh, PVL 1cc.
これに対し PVL $1 \mathrm{cc}$ によって胎

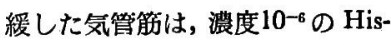
tamine 及び濃度 $10^{-8}$ の ACh に よって明らかに収縮した。すすなわ ち, Histamine 並びに ACh に対 して高い感受性を有する標本にお いてのみ PVL の気管筋弛綵作用 は現われるものと思われる.かよ うな標本について別に行った実験 において, PVL lccの示す気管筋 弛緩作用は, 濃度 $2 \times 10^{-6}$ の Histamine によって完全に拮抗され 気管筋は強く収縮した(第23図左)。 次に標本を一旦洗淮し㸷張が正常 に復した所で，投与順序を逆にし て濃度10-6の Histamine を作用せしめ，筋収縮の現われた極期に PVL $1 \mathrm{cc}$ を投与すれば，Histamine の作用

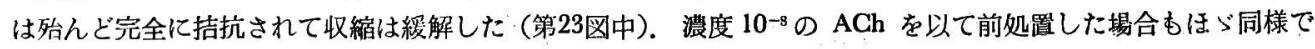
あった，しかし，同種実験において Histamine 及び ACh の濃度を僅かに高めて，夫々 $2 \times 10^{-6}$ 及び $2 \times 10^{-8}$ とすれば, PVL lccの拮抗作用はもはや不完全にしか現われない（第23図左，右）.

b. モルモット摘出肺臟気管支に対する作用

i) PVL の作用

20数例のモルモット摘出肺蔵について PVL の作用を検索した，PVL 0.2cc以下の量では流出滴数に殆んど

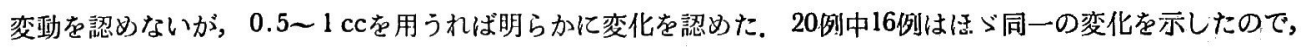
以下その代表例についてのべる，すなわち，PVL 0.5cc投与後約 $1 \mathrm{~m}$ 経過した頃より徐々に滴数の減少が現われ， 対照時に比して $10 \%$ 前後の滅少を示したが，4〜 $5 \mathrm{~m}$ 後には回復しその後は徐々に滴数が増加し始め，は 40\%の増加を示したま〉観察時間約 $30 \mathrm{~m}$ の間，変らず持続した（第24図）。すなわち，乙の実験方法においては PVL は初期数分間気管支筋を収縮せしめ，ついで拡張せしめたのである：しかし，残り 4 例においては終始滴 数減少，すなわち，気管支収縮效果のみが現われ拡張效果は見られなかった。

ii）他の楽物との関係

20例の標本について PVL.と他の楽物との関係を検索した. Adrenaline は濃度10-r溶液0.1ccを用いると, 流出滴数が対照時の $20 \%$ 或いはそれ以上に増加し，20m以上持続する。さらに濃度を高めて $10^{-6} ， 10^{-5}$ とすると， 


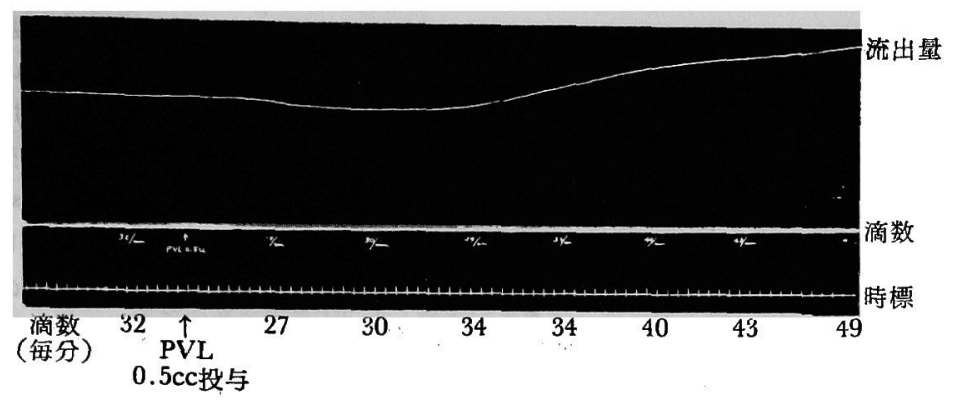

第24図.モルモット摘出気管支に対方 PVL の作用.

$4 / \mathrm{XI}{ }^{\prime} 57,15^{\circ} \mathrm{C}$, 時標 $10^{`}, 10$ 滴 $\fallingdotseq 0.8 \mathrm{cc}$, 压: $50 \mathrm{~cm}$ 水柱, PVL 0.5cc投与, 曲線の上昇は流出量增加を示す.

増加率も60\%,100\%となり，作用持続時間も30m以上に延長した．この様な Adrenaline の気管支拡張作用の極 期に PVL 0.5ccを投与すると，PVL の現わす初期収縮効果の持続時間は著しく短縮されて僅か 2 〜 $\mathrm{m}$ となり， その後は Adrenaline の単独作用時に勝る流出量の増加が認せられて，PVL の後期拡張作用が著しく増強され るのが観取された，次に投与順序を逆にして，PVL 0.5ccによって気管支收縮の起っている時期に種々の量の Adrenaline を投与してみると，濃度10-7 溶液0.1ccを用いた場合には，Adrenaline の拡張作用は可成り抑制さ
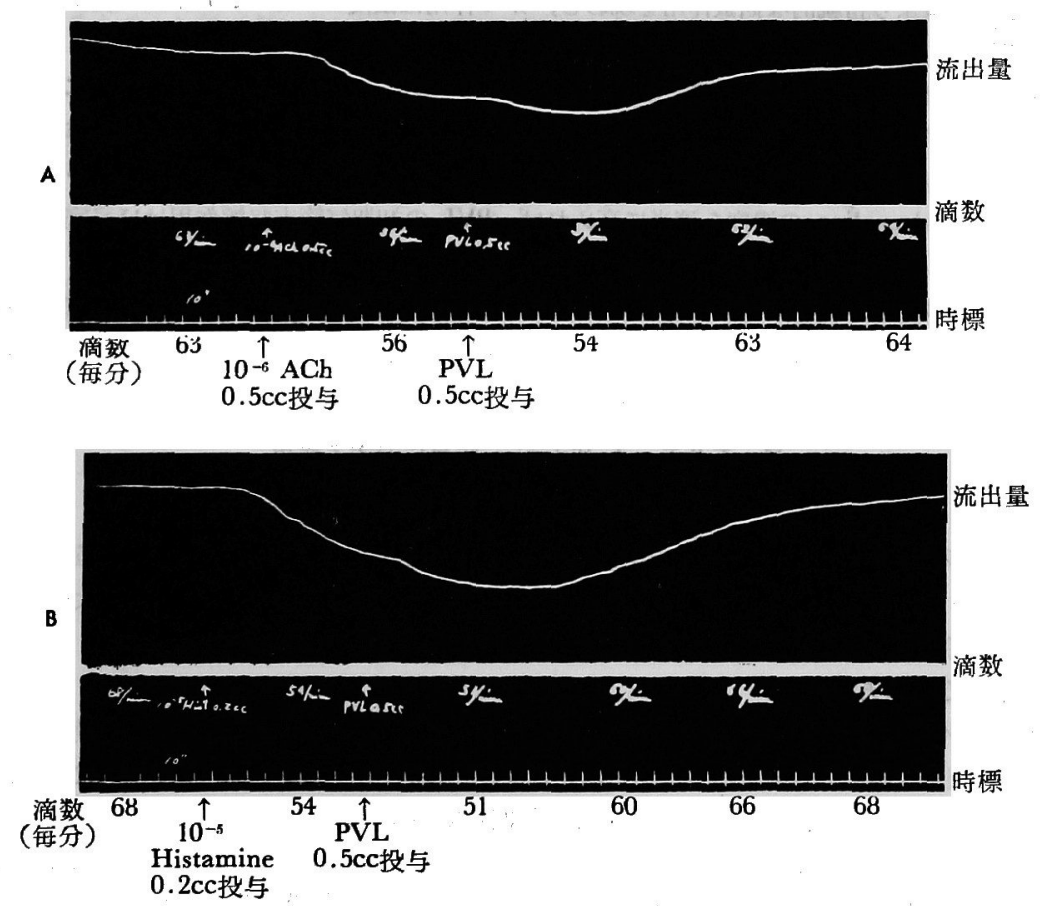

第25图. モルモット摘出気管支に扰ける PVL と ACh 及び Histamine との拮抗。

時標10`, 10 滴 $\div 0.8 \mathrm{cc}$, 正 : $50 \mathrm{~cm}$ 水柱.

A : 20/ I ' $58,15^{\circ} \mathrm{C}$, 薬物投与順, $10^{-6}$ ACh 0.5cc, PVL 0.5cc.

B : 4/XII ' $57,15^{\circ} \mathrm{C}$, 薬物投与順, $10^{-5}$ Histamine $0.2 \mathrm{cc}$, PVL $0.5 \mathrm{cc}$.

曲線の下降は流出量減少を示す。 


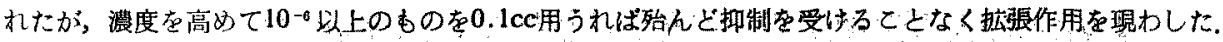

濃度 $10^{-6}$ の ACh 溶㳸0.5cc前びに濃度 $10^{-6}$ Histamine 溶波0.2ccを投与する之，10-15\%の流出量の減少

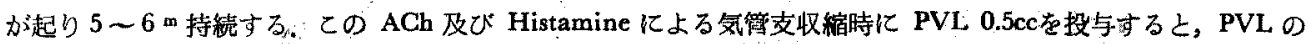
初期の収縮作用は協力的に現われて，淢少率が一層增大するが，持続時間は短縮して僅か $2 \mathrm{~m}$ 前後となり，直ち に後期拡張作用か現われて ACh または Histamine 投与前に復した。すなわち，ACh 及び Histamine の収縮 効果は，PVL の後期桩張作用のために拮抗されて持続時間が短縮し，全経過 $3 \mathrm{~m}$ にして旧に復している（第25 図A，B），忺に投与順序を逆にして PVL 0.5〜 lcc による後期抎張期に，前記之同濃度同用量の ACh または Histamine を投与しても，多くの揚合両藤物の現わすべき収縮效果は著しく減ぜられ，時には全く現かれなかっ t.

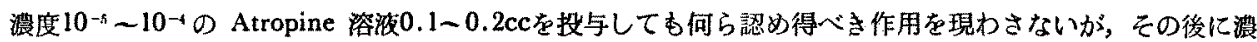
度 $10^{-6} の$ ACh 溶液0.5ccを投与すれば，その収縮作用は現われないか或いは逆に搪張が起る。しかるに PVL 0.5〜lccを投与した場合には，その初期収縮効果は前処置された Atropine とは無関係に現われた。

3. 小 括

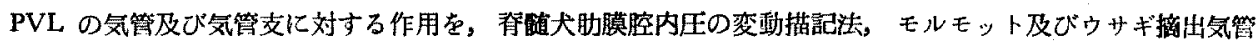

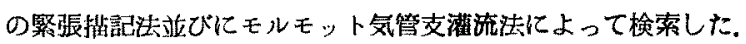

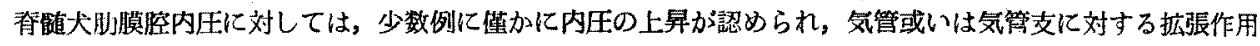
のあることを示しはしたが，余り影著ではない，モルモット及びゥサギの摘出気管に対しても，大多数の例にお いて住作用が現われなかったが，Histamine 业びに AChに対して高い感受性を示した少数例のモルモット気管

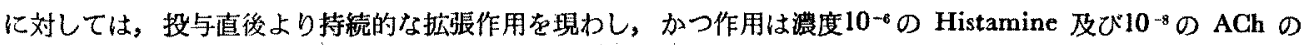
収縮作用し拮抗した。

モルモットの摘出肺䑏気管支灌流赛験では，初期一過性の収縮につぐ持続的な抎張を示す二相性の作用が認 められた。低漕度の Adrenaline を作用せしめ，その気管支拡張作用の現われた時に PVLを作用せしめると， PVL の示す初期気䉥索取縮作用は弱めら机，後期拡張作用が著しく增強された，投与の媔序を逆にした場合も

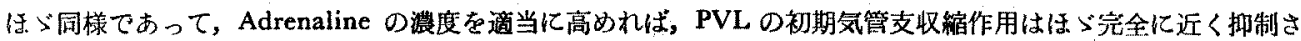
れて現われ難くなる，同じく，ACh 及び Histamine の収縮作用とは，初期協力し後拮抗した。 さらに PVLの 後期桩張作用は，ACh 及び Histamine の収維作用を著しく抑制した。次に Atropine に対する PVL の作用態度を比校すると，Atropine の前処直によって ACh の収縮作用は抑制ないし反転されるのに対し， PVL の収縮作用は殆んど影橥されることなく現われた。

\section{V. モルモット Histamine 喘息に対する作用}

\section{1. 実験陲物}

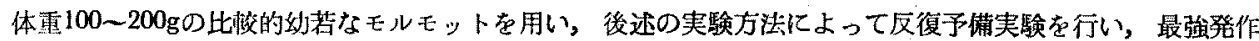

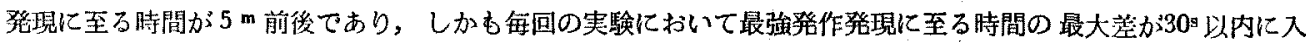
る動物を選出して实験に㒋した。

\section{2. 実検装羁及ひ実験方法}

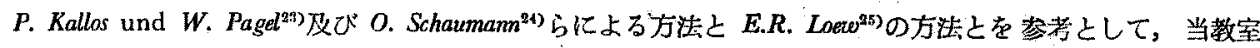

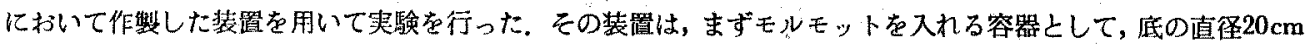
の蒸溜水用硝子瓶を利用し，乙れを高さ $25 \mathrm{~cm}$ に水平に切断して円筒形容器を作った．切口をよくすり，これに

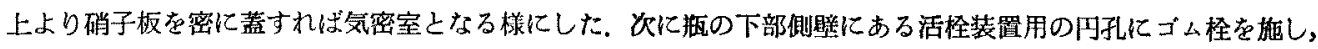
その中央に Histamine 噴露用の硝子性 Spray 取付けた. Spray は他端に 2〜3 ccの楽液を容れる目盛付 Reservoir を有し，他に二連球及び水銀 Manometer とに連結可能な 2 本の側管を储えている。以上が装䇠の概

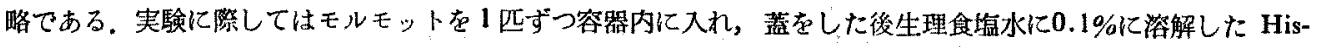

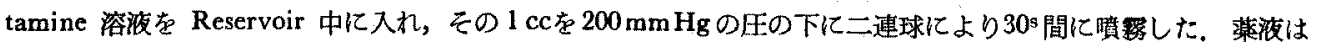

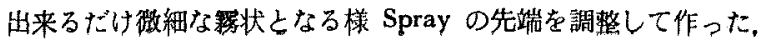




\section{3. 発作症状及びその判定}

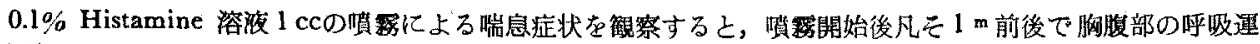

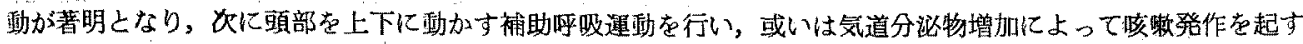

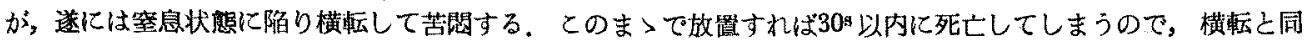

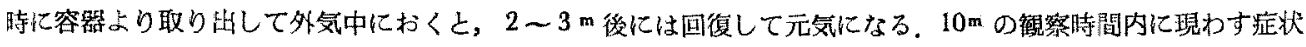

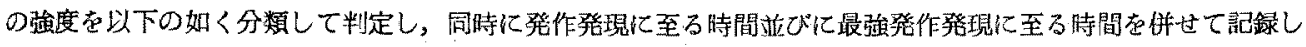
t.

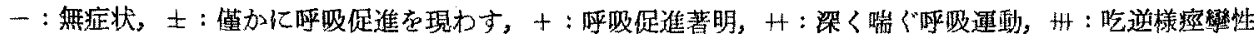
呼吸, 横転（最强症状），州：州之同様の症状なるも，回復により長い時間な要するすの.

\section{4. 喘息発作時間と個体差}

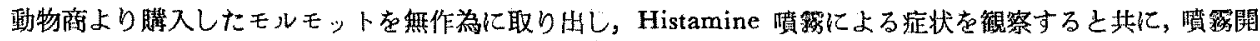
始と同時に Stop watch を発動して発作発現時間良計測してみると，モルモットの Histamine に対する感受性 は，倜体によって可成り差異があり，時間的関係においてもまたての現わす症状においても，必ずしも一様でな

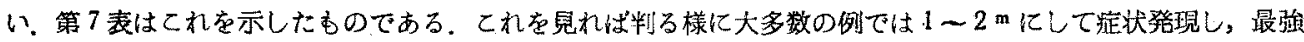

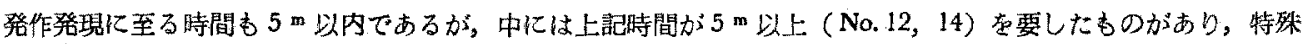

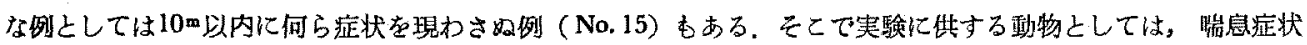
を現わすこと注無論のとと，喘息発作の時間的関係にわいて個体間の美少なく，加実験の反復によって変動す るととの少ないむのを選出する必要がある。著者はその規準として発作発見侄る時間が約 $3 \mathbf{m}$ 以内，最強発作 発現に至る時間が約 $5 \mathrm{~m}$ 以内に入るもので，しかも数回の反復実験てわいて，最強発作発現に至る時間の最大差

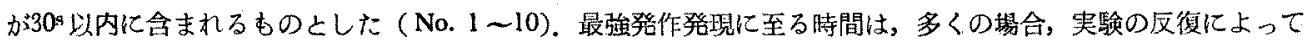

第 7表.モルモットの Histamine 喘息登作時間と個体差.

\begin{tabular}{|c|c|c|c|c|c|c|c|c|c|c|}
\hline \multirow{3}{*}{$\begin{array}{c}\text { 処 } \\
\text { 月日, 室温 } \\
\text { 動物 } \mathrm{No} . \\
\end{array}$} & \multicolumn{9}{|c|}{$0.1 \%$ Histamine 溶液 I cc貲霜 } & \multirow{3}{*}{ 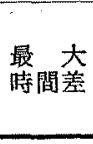 } \\
\hline & \multicolumn{3}{|c|}{$20 / \mathrm{X} \quad 57,17^{\circ} \mathrm{C}$} & \multicolumn{3}{|c|}{$21 / \mathrm{X} \quad 57,17^{\circ} \mathrm{C}$} & \multicolumn{3}{|c|}{$22 / \mathrm{XI}, 57,16^{\circ} \mathrm{C}$} & \\
\hline & 発現 & 最強 & 症状 & 発現 & 最強 & 症状 & 発現 & 最強 & 亚状 & \\
\hline 1 & $1 \mathrm{~m} 50 \mathrm{~s}$ & $3 \mathrm{~m}$ & H & $1 \mathrm{~m} 50^{\mathrm{s}}$ & $3 m$ & \# & $1 \mathrm{~m} 50^{\mathrm{s}}$ & $2 \mathrm{~m} 50^{\mathrm{s}}$ & Ht & $10^{\mathrm{s}}$ \\
\hline 2 & $1 \mathrm{~m} 50 \mathrm{~s}$ & $2 \mathrm{~m} 20 \mathrm{~s}$ & $H+$ & $1 \mathrm{~m} 40^{\mathrm{s}}$ & $2 \mathrm{~m} 20^{\mathrm{s}}$ & 世 & $1 \mathrm{~m} 40^{\mathrm{s}}$ & $2 \mathrm{~m} 20^{\mathrm{s}}$ & Ht & $10^{5}$ \\
\hline 3 & $1 \mathrm{~m} 15^{\mathrm{s}}$ & $1 \mathrm{~m} 45^{\mathrm{s}}$ & 世 & $1 \mathrm{~m} 10^{\mathrm{s}}$ & $1^{\mathrm{m}} 45^{\mathrm{s}}$ & Hit & $1 \mathrm{~m} 10^{\mathrm{s}}$ & $1 \mathrm{~m} 40^{\mathrm{a}}$ & Ht & $5^{\mathrm{s}}$ \\
\hline 4 & $1 \mathrm{~m} 40 \mathrm{~s}$ & $3 \mathrm{~m} 40^{\mathrm{s}}$ & H & $1 \mathrm{~m} 30^{\mathrm{s}}$ & $3 \mathrm{~m} 30^{\mathrm{s}}$ & 114 & $1 \mathrm{~m} 30^{\mathrm{s}}$ & $3 m 20^{a}$ & H & 20 \\
\hline 5 & $1 \mathrm{~m}$ & $1 \mathrm{~m} 30^{\mathrm{s}}$ & $H$ & $1 \mathrm{~m}$ & $1 \mathrm{~m} 30^{\mathrm{a}}$ & th & $1 \mathrm{~m}$ & $1 \mathrm{~m} 30^{\mathrm{s}}$ & H & $0^{\mathrm{s}}$ \\
\hline 6 & $1 \mathrm{~m} 40 \mathrm{~s}$ & $2^{\mathrm{m}} 30^{\mathrm{s}}$ & $H$ & $2^{m}$ & $2^{m} 45^{A}$ & \# & $2^{\mathrm{m}}$ & $2 m 25$ & H4 & $20 \mathrm{~s}$ \\
\hline 7 & $1 \mathrm{~m} 50 \mathrm{~s}$ & $2 \pi 10^{s}$ & \# & $1^{\mathrm{m}} 40^{\mathrm{s}}$ & $2 \pi 10 \mathrm{~s}$ & H & $1 \mathrm{~m} 50^{\mathrm{s}}$ & $2 \mathrm{~m} 15 \mathrm{~s}$ & $\mathrm{HH}$ & $5^{s}$ \\
\hline 8 & $2^{m} 10^{s}$ & $5^{m}$ & H & $2 \mathrm{~m} 10^{\mathrm{s}}$ & $4 \mathrm{~m} 30^{\mathrm{s}}$ & H. & $2 \mathrm{~m} 10^{\mathrm{s}}$ & $4 m 40^{s}$ & Ht & $30^{\mathrm{s}}$ \\
\hline 9 & $2 \mathrm{~m} 30^{\mathrm{s}}$ & $3^{m}$ & H & $2^{m}$ & $2 \mathrm{~m} 30^{\mathrm{s}}$ & $H$ & $2^{m}$ & $2 \mathrm{~m} 30^{\circ}$ & Ht & $30^{\mathrm{s}}$ \\
\hline 10 & $2^{\mathrm{m}} 40^{\mathrm{s}}$ & $3 \mathrm{~m} 20^{\mathrm{s}}$ & H & $2^{\mathrm{m}} 40^{\mathrm{s}}$ & $3^{\mathrm{m}} 20^{\mathrm{s}}$ & \# & $2^{\mathrm{m}} 40^{\mathrm{s}}$ & $3 \mathrm{~m} 10^{\mathrm{s}}$ & Ht & $10^{8}$ \\
\hline 11 & $4 m$ & $4 \mathrm{~m} 30^{\mathrm{a}}$ & H & $2^{\mathrm{m}} 50^{\mathrm{s}}$ & $3^{\mathrm{m}} 20^{\mathrm{B}}$ & HI & & & & $70^{\mathrm{s}}$ \\
\hline 12 & $4 m$ & $5^{\mathrm{m}} 40^{\mathrm{s}}$ & $H$ & $2^{\mathrm{m}} 40^{\mathrm{s}}$ & $3^{m} 15^{\circ}$ & H & & & & $85^{s}$ \\
\hline 13 & $3 \mathrm{~m} 30 \mathrm{~s}$ & $4^{m}$ & $H$ & $2 \mathrm{~m} 30^{\mathrm{s}}$ & なし & $H$ & & & & 不明 \\
\hline 14 & $8^{m}$ & なし & \pm & $5^{\mathrm{m}} 45^{\mathrm{s}}$ & なし & + & & & & 不明 \\
\hline 15 & なし & \$L & - & なし & なし & - & & & & 不明 \\
\hline
\end{tabular}

発現：発怍発現に至万時間。

最强: 最強発作 (卅) 発現に至万時間。

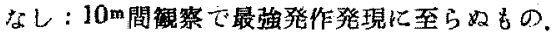

最大時間差：各湖体の最強発作発現に至る時間の最大差。

应状山本交参照。 
次第に短縮する傾向を示すのが認められた (No. 8，9，12など)、

\section{5. 実釱成綪}

1) PVL と Histamine の同時喷苏実駼

55匹のモルモットを選比し，前日に0.1 of Histamine 溶源 l cc学籍して, 各個体 の発作発現に至る時間及び䟲貟発作癹現に至

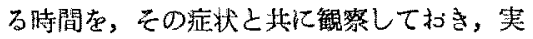
験当日には Histamine 索生理食㙁水に溶解 する代りに PVL に0.1\%上なる様溶解し，

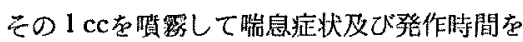
観察した。

結果住第 8 表に示す如く，15例中 2 例は 全く無症状であり (No.16，17)，4例は症 状柽減して最強登作を現わすに至らず（No. $18 ， 19 ， 20 ， 21) ， う 53$ 例は発作発現に至 る時間も延長した（No. 18，19，20)。その 他にも発作発現侄る時間及び最強発作発現 亿至る時間か唌長したものが数例ある，しか し，中には殆んど対照時と差異のない例もあ り，それのみか反対に上钎時間がもしろ短縮 し，最強発作老持続する時間が延長する例 (No. 28，29，30) の現われたととは注目をひいた。

この央験方法では PVL に合まれる蛋白質と Histamine との間に，in vitro 亿おいて可らかの反応が起って

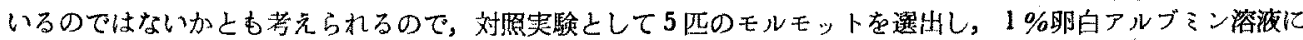

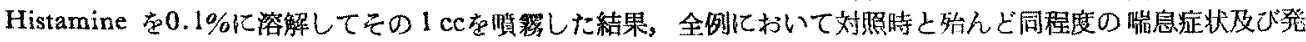
作時間が観察され，卵白アルブミンの影響は全く兒られなかった。

\section{2) PVL 及び Diphenhydramine 前処置後の Histamine 喷程実駼}

10匹のモルモットを選出し，PVL 3ccを大々腹腔内に注射し，1 h，6h 及び24h後の各㭙間に計 3 回 Hista-

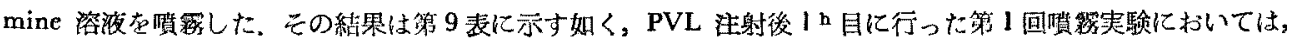

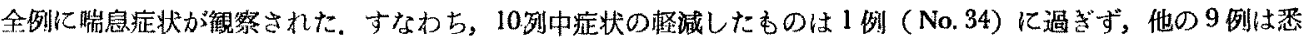
く最強発作を現わし，中 3 例（No.38，39，40）はとの持続時間か梴脣し，外気中での回復に時間を要した，し

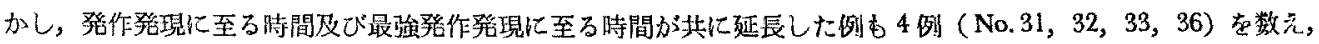

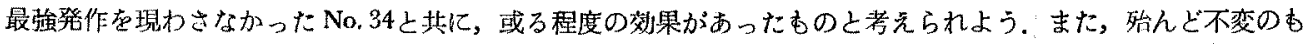

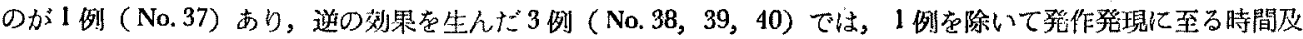
び最㤝発作発䍐に至る时間が䂑綰している。

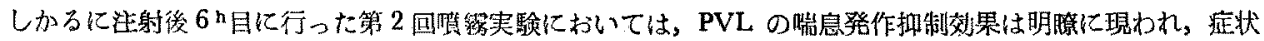
の全く或いは殆んど現わ机ないもの計 3 例（No.31，32，33），柽娍したもの2 例 (No.34，35）と增加し，残 る実験例李悉く（No.36はや〉例外）登作発現に至る時間並びに最強発作発現に至る時間が前回に比して延唇し ている。

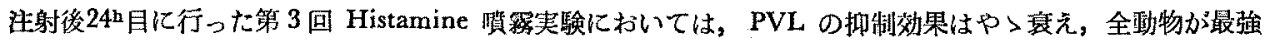

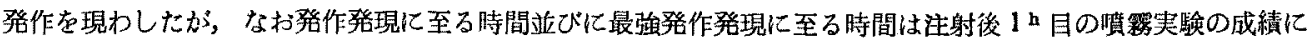
比して概小延長しており，かつ二，三の例においてはその度合が著明である。

次に冽に 5 匹のモルモットを用い，0,1\% Diphenhydramine 溶液を $10 \mathrm{mg} / \mathrm{kg}$ 割合に腹腔内に注射し，乙 
第 9表.モルモットの Histamine 腨息に対する PVL 及び Diphenhydramine の作用比較.

\begin{tabular}{|c|c|c|c|c|c|c|c|c|c|c|c|c|}
\hline \multirow{4}{*}{$\begin{array}{c}\text { 前 処 圈 } \\
\text { 月日, 室温 } \\
\text { Histamine 噴稀 } \\
\text { 動物 No. }\end{array}$} & \multirow{3}{*}{\multicolumn{3}{|c|}{$\begin{array}{c}\text { な } し \\
28 / \times{ }^{\circ} 57,17^{\circ} \mathrm{C} \\
\text { 奶 照 }\end{array}$}} & & \multicolumn{8}{|c|}{ PVL 3cc腹腔内注射 } \\
\hline & & & & \multicolumn{5}{|c|}{$29 / \mathrm{X} \quad 57,17^{\circ} \mathrm{C}$} & \multirow{2}{*}{\multicolumn{4}{|c|}{ 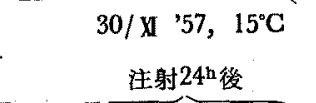 }} \\
\hline & & & & \multicolumn{3}{|c|}{ 注射Ih後 } & \multicolumn{2}{|c|}{ 注射 $6^{\text {h }}$ 後 } & & & & \\
\hline & 登現 & 最強 & 定状 & 発現 & 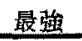 & 症状 & 発現 & 叟強 & 症状 & 登現 & 最㧧 & 应状 \\
\hline 31 & $2 \mathrm{~m} 10^{\mathrm{s}}$ & $3 \mathrm{~m} 20 \mathrm{~s}$ & H & $3 \mathrm{~m} 20^{\mathrm{s}}$ & $4 \mathrm{~m} 30^{\mathrm{s}}$ & $H$ & なし & なし & - & $7 \mathrm{~m} 15^{\mathrm{s}}$ & $8^{m}$ & Ht \\
\hline 32 & $2 \mathrm{~m} 50 \mathrm{~s}$ & $3 \mathrm{~m} 20 \mathrm{~s}$ & H & $3 \mathrm{~m} 10^{\mathrm{s}}$ & $3 \mathrm{~m} 25^{8}$ & \# & なし & なし & - & $6 \mathrm{~m} 20^{\mathrm{s}}$ & $7 \mathrm{~m} 30^{\mathrm{s}}$ & 世 \\
\hline 33 & $3 \mathrm{~m} 15^{\mathrm{s}}$ & $4 \mathrm{~m}$ & $\mathrm{Ht}$ & $3 \mathrm{~m} 50^{\mathrm{g}}$ & $4 m 30^{\circ}$ & \# & $4^{m}$ & なL & \pm & $4 \mathrm{~m}$ & $8^{\mathrm{m} 20^{\mathrm{s}}}$ & H \\
\hline 34 & $2 \mathrm{~m} 30^{\mathrm{s}}$ & $3 \mathrm{~m} 30^{\mathrm{s}}$ & H & $2^{m}$ & th & + & $3 \mathrm{~m} 20^{\mathrm{B}}$ & なし & $H$ & $2 m$ & $2 \mathrm{~m} 45^{\mathrm{s}}$ & 世 \\
\hline 35 & $1 \mathrm{~m} 40^{\mathrm{s}}$ & $2 \mathrm{~m} 30^{\mathrm{s}}$ & $H$ & $1 \mathrm{~m} 20^{\mathrm{s}}$ & $2 \mathrm{~m} 40^{\mathrm{s}}$ & 世 & $3 \mathrm{~m} 50^{\mathrm{s}}$ & なし & $H$ & $3 \mathrm{~m} 30^{\mathrm{s}}$ & $5^{\mathrm{m}} 20^{\mathrm{s}}$ & \# \\
\hline 36 & $1 \mathrm{~m} 30^{\mathrm{s}}$ & $2 \mathrm{~m} 30^{\mathrm{s}}$ & H & $2 \mathrm{~m} 30^{\mathrm{s}}$ & $4 \mathrm{~m}$ & $H$ & $1 \mathrm{~m} 50 \mathrm{~s}$ & $7 \mathrm{~m}$ & 世 & $2 m$ & $4^{m}$ & tH \\
\hline 37 & $1 \mathrm{~m} 30^{\circ}$ & $2^{\mathrm{m}}$ & H & $1 \mathrm{~m} 20^{\mathrm{s}}$ & $2^{m}$ & m & $2 \mathrm{~m} 10^{\mathrm{s}}$ & $3^{m}$ & Ht & $1 \mathrm{~m} 45^{\mathrm{s}}$ & $2^{\mathrm{m}} 20^{\mathrm{s}}$ & H \\
\hline 38 & $4 \mathrm{~m} 15^{\mathrm{s}}$ & $5^{\mathrm{m}} 15^{\mathrm{s}}$ & $H$ & $1 \mathrm{~m} 30^{\mathrm{s}}$ & $3 m$ & HA & $5^{\mathrm{m}}$ & $6 \mathrm{~m} 20^{\mathrm{s}}$ & H & $3 \mathrm{~m} 20^{\mathrm{B}}$ & $6^{m} 50^{\mathrm{s}}$ & \# \\
\hline 39 & $1 m$ & $1 \mathrm{~m} 30^{\mathrm{s}}$ & H & $1 \mathrm{~m}$ & $1 \mathrm{~m} 15^{8}$ & $H H$ & $1 \mathrm{~m} 10^{\mathrm{s}}$ & $1 \mathrm{~m} 45^{\mathrm{s}}$ & $H$ & & & \\
\hline 40 & $2^{\mathrm{m}} 30^{\mathrm{s}}$ & $3 \mathrm{~m}$ & H & $1 \mathrm{~m} 30^{\mathrm{s}}$ & $2 \mathrm{~m} 10^{\mathrm{s}}$ & $\mathrm{HH}$ & $2^{m}$ & $3^{\mathrm{m}}$ & H & & & \\
\hline 前処讟 & & $L$ & & & $0.1 \%$ & Diphe & hydran & ine $10 \mathrm{~m}$ & $\mathrm{ag} / \mathrm{kg}$ & 膄腔内注 & & \\
\hline 41 & $1 \mathrm{~m} 50^{\mathrm{s}}$ & $3 \mathrm{~m}$ & $H$ & なし & なし & - & $1 \mathrm{~m} 50^{\mathrm{s}}$ & なし & $H$ & $1 \mathrm{~m} 50^{\mathrm{s}}$ & $3^{\mathrm{m}}$ & $H$ \\
\hline 42 & $1 \mathrm{~m} 30^{\mathrm{s}}$ & $1 \mathrm{~m} 50 \mathrm{~s}$ & H & $4^{\mathrm{m}} 50^{\mathrm{s}}$ & sL & $H$ & $2 \mathrm{~m} 20^{\mathrm{s}}$ & \&L & H & $1 \mathrm{~m} 30^{\mathrm{s}}$ & $2^{\mathrm{m}}$ & H \\
\hline 43 & $1 \mathrm{~m} 10^{\mathrm{s}}$ & $1 \mathrm{~m} 45 \mathrm{~s}$ & \# & $7^{m}$ & なし & $H$ & $3 \mathrm{~m} 40^{\mathrm{s}}$ & $5 \mathrm{~m} 10^{\mathrm{s}}$ & $\mathrm{Ht}$ & $1 \mathrm{~m}$ & $1 \mathrm{~m} 40^{\mathrm{s}}$ & H \\
\hline 44 & $1 \mathrm{~m} 25^{5}$ & $2^{\mathrm{m}} 50^{\mathrm{s}}$ & Ht & $8^{m}$ & なし & \pm & $1 \mathrm{~m} 30^{\mathrm{s}}$ & $2^{\mathrm{m}} 30^{\mathrm{s}}$ & H & $1 \mathrm{~m} 20^{\mathrm{s}}$ & $2 \mathrm{~m} 50^{\mathrm{s}}$ & H \\
\hline 45 & $1 \mathrm{~m} 50^{\mathrm{s}}$ & $3^{m}$ & m & $2 \mathrm{~m} 20^{\mathrm{s}}$ & $2^{\mathrm{m}} 50^{\mathrm{s}}$ & $H$ & & & & & & \\
\hline
\end{tabular}

略号は第 7 表に同し。.

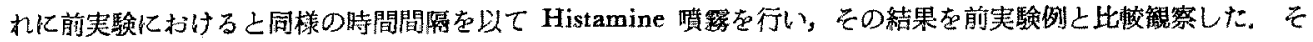

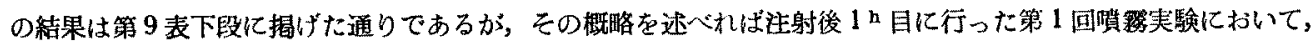
すで全く症状を現わさないもの，或いは殆んど現わさないもの 2 例 (No. 41，44)，柽減したもの2 例 (No.42， 43), 不変のもの1例 (No.45)であり, 最後の例を除いては発作発現に至る時間もかなり延長しており; 明らか に Diphenhydramine の Histamine 喘息抑制作用が諗められる.しかし，6h 後の第 2 回䀧籍実験においては，

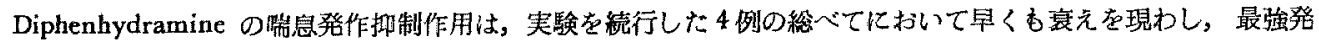
作発現の抑制されたものこそ2例はあるが，全般的にみて発作症状は前回に比して強まり，時閪的関係に执いて

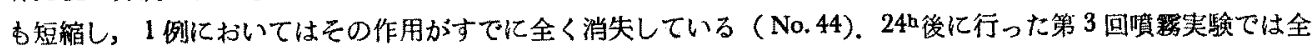
例の悉くにわいて，対照時之同等の成績を示し，Diphenhydramine の作用は全く消失した。

以上の実験例の示す所では，Diphenhydramine の抗 Histamine 㘯果は注射後 1 亿におてすでに速かに現 われているのに対し，PVLのは〉同程度の效果は6 $\mathrm{h}$ 後にわいて遮れて現われており，前者はこの時刻にはすて

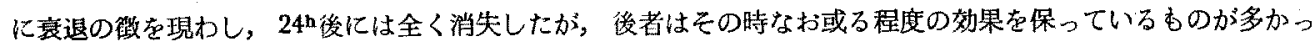
たのであり，雨者間には作用の発現時間に荤速が認められ，恐らくはそれと共に，持続時間にも長短の差暴があ るととつ思われた。

6.小 括

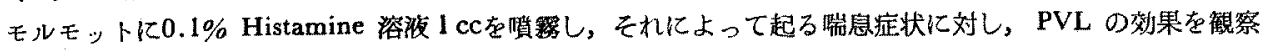
し 彫せて Diphenhydramine の作用と比較した.

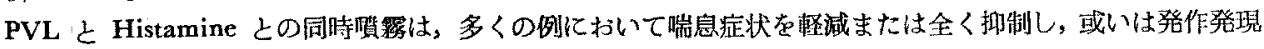

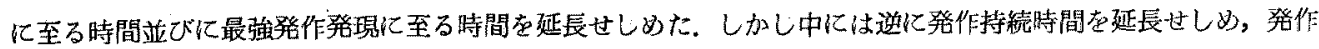
発現に至る時間及び最強発作発現に至る時間を短縮した例も現われた，PVL の代りに卵白アルブミンを使用し た場合には，とれらの作用は全く認められない。 


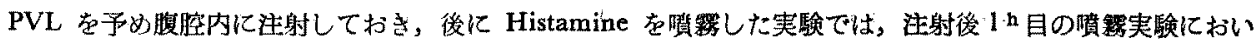
ては䄪半数に軽度の效果が照められ、残りの半数は逆に Histamine に敏感となったもの及び然效例であった。

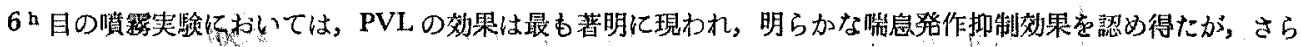
に24h目にあ或る程度の效果か残存していた。 これに対し Diphenhydramine の抗 Histamine 作用は，注射後

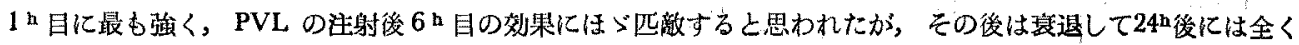

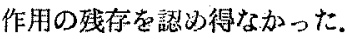

\section{VI. 血管運動神経中枢及ひ呼吸中枢に対する作用}

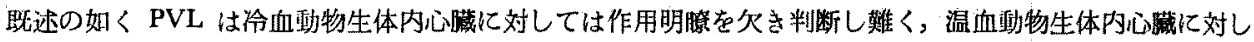

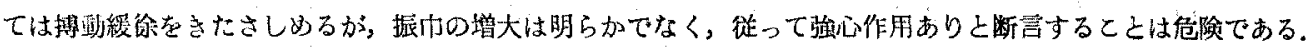
次に血管に対する作用は如何というに，ガマ血第灌流実験において，夏季より秋季にかけては血管抁張作用のふ

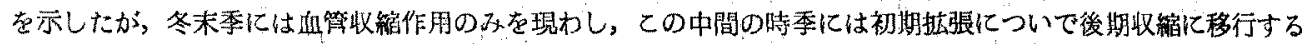
二相性の作用を現わした，温血動物において，かような季節的変動が起万うとは考え難いが，もし血绉を収縮せ

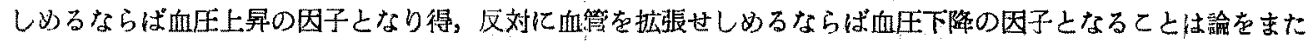

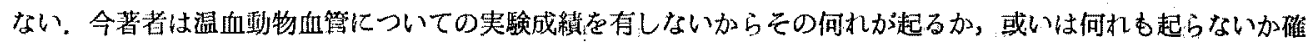

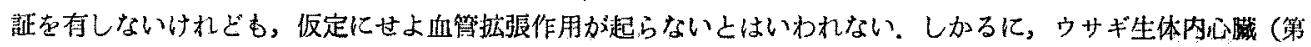

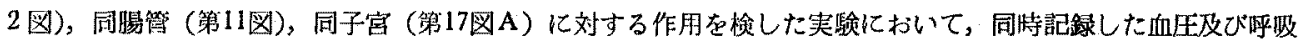

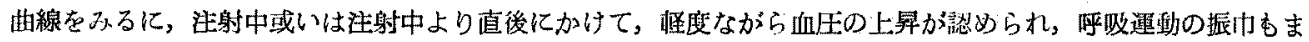

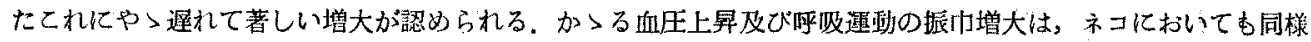

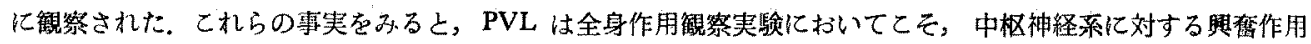

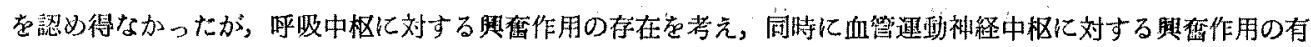

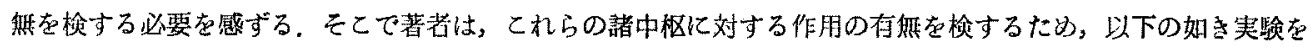
行った.

\section{1. 実験動物及ひ実験方法}

\section{1) ガマ血管军動神程中权に関する実倹法}

体重200 300gのガマを用い，10\% Urethane 溶没を3.5 4 cc/100gの覀 合に皮下に注射して麻醉を施し，Schmidt 浩に従って夷験を行った，灌流液に は $0.8 \%$ 割合に Glucose を加えた $\mathrm{O}_{2}$ 飽和 Ringer 液を用いた。灌流生は頭部

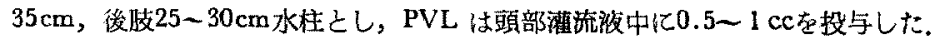
なお，滴数20ケは0.9ccに相当する。

\section{2）ウサギ血管運陲神释中枢及び呼吸中枢に関する実験法}

体重 2 - $3 \mathrm{~kg}$ のウサギを用い，10\% Urethane 溶液を $1 \mathrm{~g} / \mathrm{kg}$ の割合䎲皮

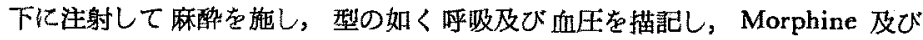

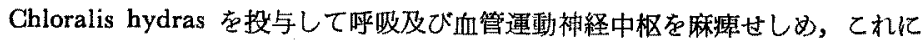
PVL を投与して呼吸及び血圧に対する影響を潩祭した。

\section{2. 実験成唃}

1）ガマ血管運動神䅅中枢に対する作用

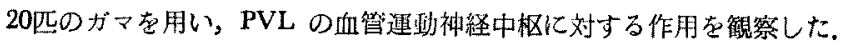
PVL 0.5１ccを頭部灌流液中に注入すると，大多数の実験例にわいて後肢

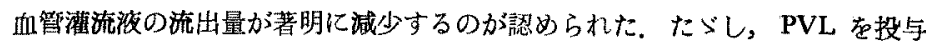

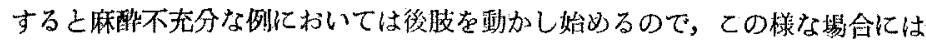
龭部灌流液中に適宜: Urethane 溶液を追加灌流した。以下比輅的長時間の観察 を行い得た例についてその経過なのべる，すなわち，PVL Iccの注射㨁後より， 後肢血管灌流滩の流出量は著明に減少し，これを滴数について観察すれば，注
第10表

ガ、血管遇趿神経中权 亿対すっ PVL の作用 (Schmidt 法).

\begin{tabular}{c|c}
\hline \hline 時間(分) & $\begin{array}{c}\text { 滴 数 } \\
(\text { 整召) }\end{array}$ \\
\hline-1 & 83 \\
-0.5 & 84 \\
処置 & PVL lcc投与 \\
1 & 82 \\
2 & 76 \\
3 & 68 \\
4 & 56 \\
5 & 54 \\
6 & 58 \\
7 & 64 \\
8 & 68 \\
9 & 74
\end{tabular}

$26 / \mathrm{X} ' 58,230 \mathrm{~g}, \quad ㅇ ㅜ, 10 \%$ Urethane $3.5 \mathrm{cc} / 10 \mathrm{~g}$ 皮下注 射, 20 滴 $\div 0.9 \mathrm{cc}$, 压: 頭部 $35 \mathrm{~cm}$, 後肢 $25 \mathrm{~cm}$ 水柱, PVL 1 cc投与，与注射の開 始，終了を示守。 
射後 4〜 $5 \mathrm{~m}$ にして極盛期に達し，対照時に比し35\%以上の诚少を示し，その後回復㑯向を現わした（第10表）. ての実験成積より PVL には，ガマ血管運動神経中枢を與奞せしめる作用のあることが明らかである.

2）ウサギ血管遇峌神蛏中枢及び呼吸中枢に対する作用

a. Chloralis hydras に対する拮抗作用

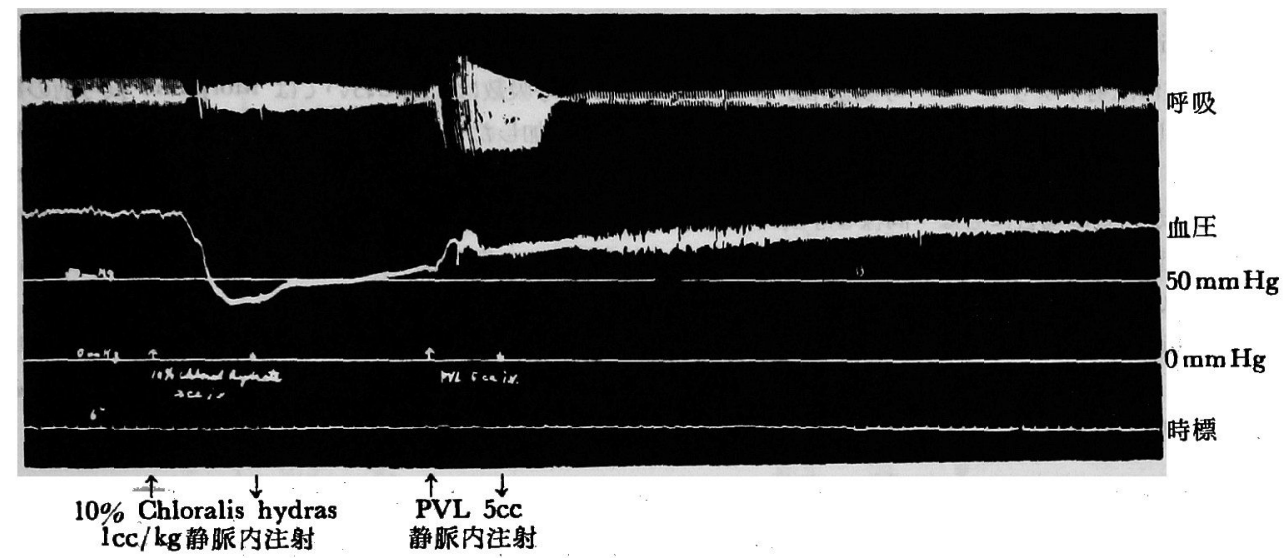

第26图. Chloralis hydras 投与ウサギ库吸及び血正に及ぼす PVL の影整.

$24 /$ XI $58,22^{\circ} \mathrm{C}, 2 \mathrm{~kg}$, 古，10\% Urethane $1.3 \mathrm{~g} / \mathrm{kg}$ 皮下注射，時標6”，

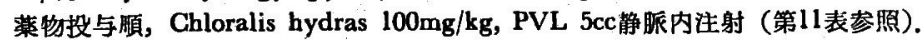

第11表. Chloralis hydras 投与ウサギ呼级及び血压に 及ぼす PVL の影慜 (第26图参照).

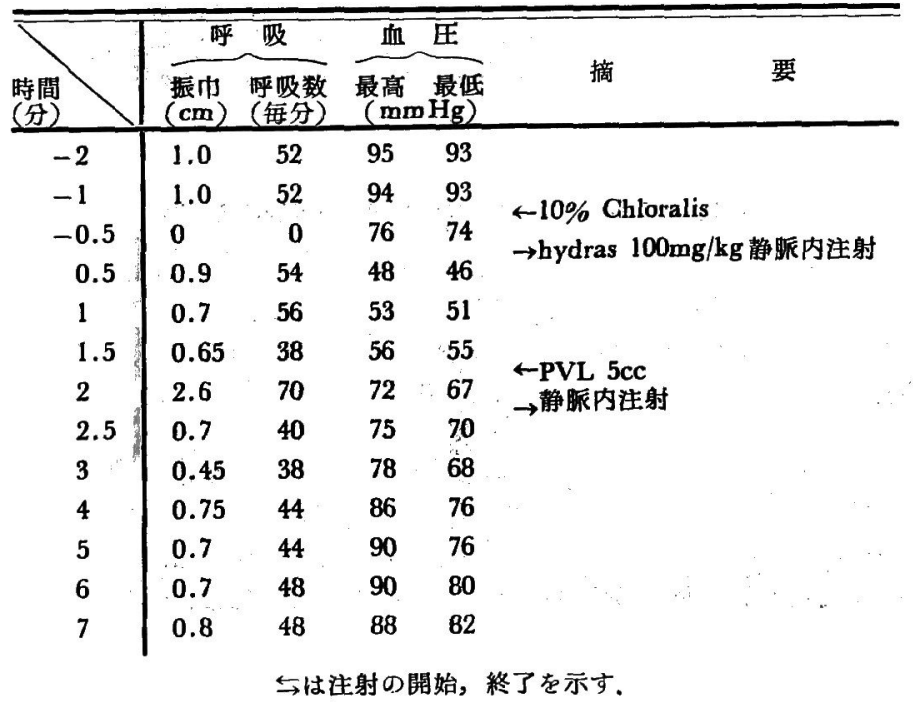

4 匹のウサギを用い， Ghloralis hydras t投与して 血管運動神経中权及び呼吸中 权の麻瘏を起さしぬ，その後 に PVL を投与しててれに対 する影響を権察した。

10\% Chloralis hydras 溶液を50 - $100 \mathrm{mg} / \mathrm{kg}$ の割合 で静脈内に注射すると，直ち に 40 60 $\mathrm{mmHg}$ の血圧下降 をきたし，5〜6 m 持続して 徐々に回復する、その祭呼吸 運動は一過性に停止するが， 值ちに再開されて 数 $10^{8}$ 間旺 盛となった後再度振巾を減じ， 呼吸数もまた減少する。この 血圧下降及び呼吸柳制期に PVL 5一-10ccを静脈内に投与 すると，2例において注射中

に血圧の上昇を認め得た（第26図及び第11表）が，他の 2 例においては余り著しい作用が認められなかった。

一方呼吸に対しては全例に注射中及ぴ直後に，著しい呼吸数及び振巾の増大が現われ約 $1 \mathrm{~m}$ 間持晩するのが

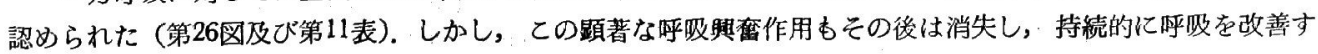
るとは思われなかった。 


\section{b. Morphine に対する拮抗作用}

9 匹のウサギを使用した. $0.4 \%$ Morphine 溶液を 1 ～2 mg/ kg の割合で狰脈内に注射すれば，呼吸運動の 振巾は僅かに娍少するが，特に呼吸数の娍少が著明に起り，汪射後 $5 \mathrm{~m}$ 前後には 4 10/min の堿少を現わした. $4 \sim 6 \mathrm{mg} / \mathrm{kg}$ を投与すれば特有の Cheyne Stokes 型呼吸をする。乙の恡重2 様の呼吸抑制䎲対する PVL の作用 を锶察した.

Morphine $2 \mathrm{mg} / \mathrm{kg}$ の投与によって柽度の呼吸抑制状態にあるすの 2 例について，PVL $5 \mathrm{cc}$ を静脈内に注射 すると，共注射中より1〜 $2 \mathrm{~m}$ 呼吸振巾が著明に増大した。呼吸数は1例においては Morphine 段与前の数 にまで回復し，他の 1 例においてはそれ以上にまで増加した. 増加したものは約 $3 \mathrm{~m}$ にして旧に復したが, 呼吸 数の回復は Chloralis hydras の㛫合之異なり永続的であった (第27図及び第12表A). 別の 2 例には PVL 10cc

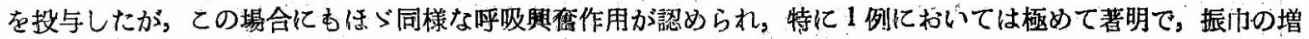
大と共に呼吸数が增加し，PVL 投与前の 6 倍以上にむ激增し，その復旧までの時間む，振巾においては 5 m, 呼吸数においては $30 \mathrm{~m}$ を要した.

Morphine $4 \mathrm{mg} / \mathrm{kg}$ を投与した実験例 4 例については，著明な承吸抑制の現われた時期に PVL 10ccの投与 を試みた. その結果 1 例では一過性に呼吸数の增加が現われたに過ぎなかったが，他の 3 例では特有な CheyneStokes 型呼吸が全く消失して再び現われなかった（第27図及び第12表 B).
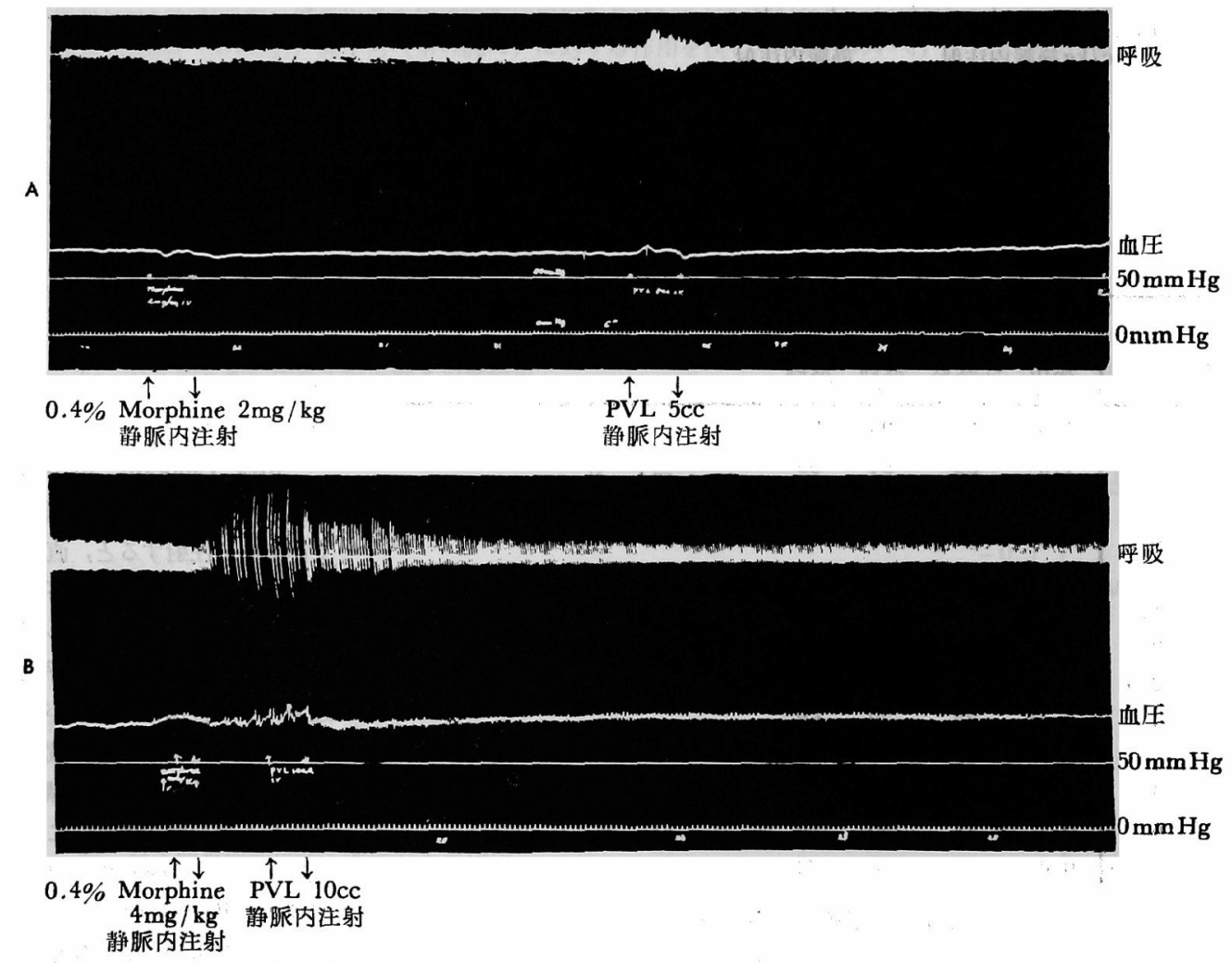

第27図. Morphine 投与ウサギ呼吸及び血圧に及ばす PVL の影響.

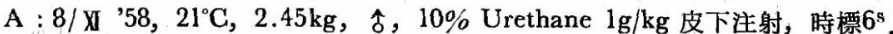
薬物投与順, Morphine $2 \mathrm{mg} / \mathrm{kg}$, PVL 5cc静脈内注射 (第12表例 A 参照).

B : 7/XI '58, $21^{\circ} \mathrm{C}, 2.5 \mathrm{~kg} ， \hat{\delta} ， 10 \%$ Urethane $\mathrm{lg} / \mathrm{kg}$ 皮下注射，時標 $6^{\mathrm{s}}$. 薬物投与順，Morphine $4 \mathrm{mg} / \mathrm{kg}$, PVL $10 \mathrm{cc}$ 静脈内注射 (第12表例 B 参照). 


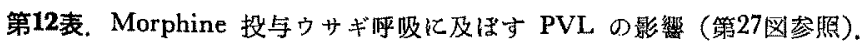

\begin{tabular}{|c|c|c|c|c|c|c|c|}
\hline \multirow{2}{*}{ 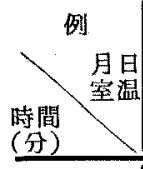 } & \multicolumn{3}{|c|}{$\begin{array}{c}\mathrm{A} \\
8 / \mathrm{XJ} \\
{ }^{\prime} 58,21^{\circ} \mathrm{C}\end{array}$} & \multicolumn{4}{|c|}{$\begin{array}{c}\text { B } \\
7 / \mathrm{XI} \quad 58, \quad 21^{\circ} \mathrm{C}\end{array}$} \\
\hline & $\begin{array}{c}\text { 振巾 } \\
(\mathrm{cm}) \\
\end{array}$ & $\begin{array}{l}\text { 呼吸数 } \\
(\text { 每分) }\end{array}$ & 挏 & $\begin{array}{l}\text { 振门 } \\
(\mathrm{cm})\end{array}$ & $\begin{array}{l}\text { 呼吸数 } \\
\text { (短分) } \\
\end{array}$ & 摘 & 要 \\
\hline-2 & 1.1 & 35 & \multirow{12}{*}{$\begin{array}{l}\stackrel{5}{0.4 \%} \% \text { Morphine } \\
2 \mathrm{mg} / \mathrm{kg} \text { 哂脈内注射 }\end{array}$} & 1.3 & 36 & \multirow{22}{*}{\multicolumn{2}{|c|}{$\begin{array}{l}\stackrel{\leftarrow}{\rightarrow} 0.4 \% \text { Morphine } \\
4 \mathrm{mg} / \mathrm{kg} \text { 䢂脤内注射 } \\
\leftarrow \text { PVL } 10 \mathrm{cc} \text { 静脈内注射 } \\
\rightarrow\end{array}$}} \\
\hline-1 & 1.1 & 35 & & 1.2 & 35 & & \\
\hline 1 & 1.1 & 32 & & 2.3 & 10 & & \\
\hline 2 & 1.0 & 32 & & 4.0 & 10 & & \\
\hline 3 & 1.0 & 32 & & 1.8 & 18 & & \\
\hline 4 & 0.9 & 32 & & 1.8 & 18 & & \\
\hline 5 & 0.9 & 31 & & 1.3 & 20 & & \\
\hline 6 & 0.9 & 31 & & 1.0 & 22 & & \\
\hline 7 & 1.0 & 31 & & 0.9 & 23 & & \\
\hline 8 & 1.0 & 31 & & 0.9 & 23 & & \\
\hline 9 & 0.9 & 31 & & 0.8 & 23 & & \\
\hline 10 & 1.0 & 31 & & 0.7 & 23 & & \\
\hline 11 & 1.0 & 31 & \multirow{10}{*}{$\underset{\rightarrow}{\leftarrow} \mathrm{PVL} 5 \mathrm{cc}$ 静眽内注射 } & 0.7 & 23 & & \\
\hline 12 & 2.0 & 39 & & 0.7 & 23 & & \\
\hline 13 & 1.3 & 36 & & 0.8 & 23 & & \\
\hline 14 & 0.9 & 34 & & 0.8 & 23 & & \\
\hline 15 & 0.8 & 34 & & 0.7 & 23 & & \\
\hline 16 & 0.9 & 34 & & 0.7 & 23 & & \\
\hline 17 & 0.8 & 34 & & 0.8 & 23 & & \\
\hline 18 & 0.9 & 34 & & 0.8 & 23 & & \\
\hline 19 & 0.8 & 34 & & 0.8 & 23 & & \\
\hline 20 & 0.8 & 34 & & 0.8 & 23 & & \\
\hline
\end{tabular}

しかしながら，Morphine を增量して $6 \mathrm{mg} / \mathrm{kg}$ 以上を用いた揚合には，あはや PVLは Morphine の呼汲 中权䅛猈作用に対して充分拮抗することが出来なくなった。

以上の如く PVL には Morphine のウサギ呼吸中枢に対する麻瘦作用に拮抗し，乙れる與奮せしめる作用 る有するてとが明らかである。

\section{3. 小 括}

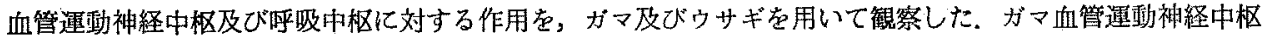

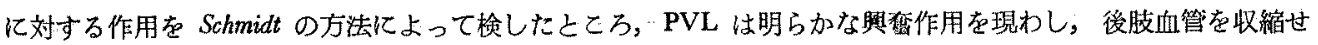

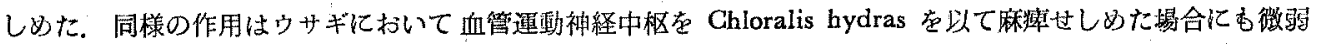
ながら認めることが出来た．この際同時に観察した Chloralis hydras の乎吸麻痺作用に対する 拮抗作用は顕著 であり，明らかに呼吸中枢の興巂が認められた。

呼吸中枢に対守る作用は，別にウサギに Morphine 歨与えて呼吸中枢を麻獀せしる，乙れに対する PVLの

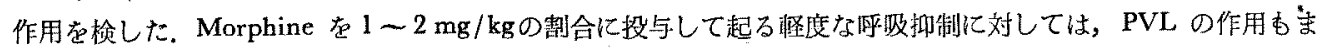
たあまり著明ではないが，一過性の呼吸運動の振门增大と，それに綄く呼吸数の持続的な增加が認められた。 Morphine $4 \mathrm{mg} / \mathrm{kg}$ の投与によって現われた中等度の呼吸抑制に対しては，大量の PVLは期らかな呼吸舆磨作 用を現わし，殊にCheyne-Stokes 型呼吸を全く消失せしめる作用が認められた。 


\section{PVL とACh との比較並びに ChE に対する作用}

PVL の諸蔵器に対する作用のうちには，ACh と類似の作用を現わす面があるが，ACh とは相違すること も多くの実験で示された，しかしながら，著者はこの点を一層深く追求するために，改めてカエル腹直筋を用い て ACh との比較を試み，その結果に基づいて ChE に対する作用を，化学的方法並びに生物学的方法を用いて 検索した.

1. カエル腹直筋における PVL と ACh との作用比較

1）実験動物及び実験方法

体重 $20 \mathrm{~g}$ 前後のカエルを使用し，Burn の方法 ${ }^{26)}$ と従って実験を行った。 すなわち，腹直筋を一側ずつ摘出し， 各片はカエル用 Ringer 液中に浸して氷室内に保存し，24h 後に使用した．実験に際しては，腹直筋を内容10ccの Magnus 管中に懸垂し，これに一側より絶えず空気を送入した. ACh 及び他の薬物を作用せしむるには，予めと れらを所要の濃度に Ringer 液に溶解しておき，その10ccを Magnus 管中の Ringer 液と交換した，交換終了之 同時に Kymographion を動かし，Stop watch にて計時した90s間の収縮を 描記せしめ，時間終了と同時に Kymographion を停止した，炊の収縮を描記するには，直後に Ringer 液と交換放置し，ついで 3 m 間隔でなお 2 回 Ringer 液の交換を行い, 計 3 回約 $10 \mathrm{~m}$ 間洗溫した後に行った.

\section{2) 実験成績}

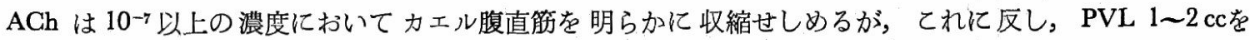
Ringer 液 9 8 cck稀橎して作用せしめてあ全く収縮が起らない(第28図).

しかしながら，PVL を一定時間作用せしめた後，洗涤することなく ACh を作用せしめると，その収縮高 は增大した。すすなわち，PVL 2ccを Ringer 液 $8 \mathrm{cc}$ に稀釈し腹直筋に $5 \mathrm{~m}$ 間作用せしめた後，直ちに $10^{-7}$ の浱度

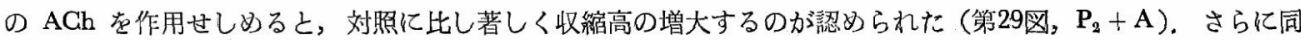
㥞操作により PVL $1 \mathrm{cc}$ 用いた場合には，前者よりもや〉弱いがやはり収縮高の増大が認められた（第29図， $\left.\mathrm{P}_{1}+\mathrm{A}\right)$.
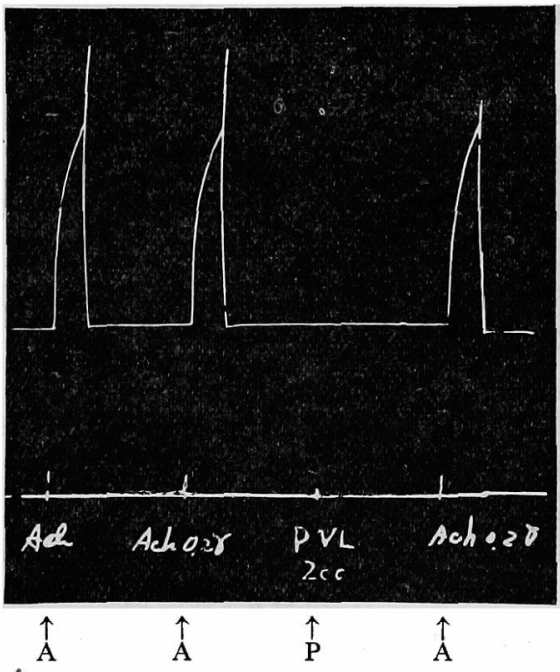

第28図。カエル腹直筋に対する PVL と ACh との作用比較.

16 / XI '56， $17^{\circ} \mathrm{C}$ ，管内液量 $10 \mathrm{cc}$, 90`の収縮を示す. A : $2 \times 10^{-7}$ ACh, P : PVL 2cc/10cc.

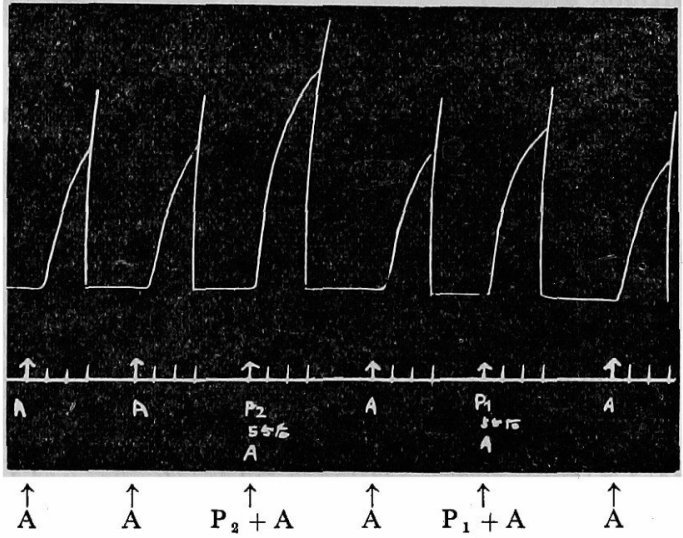

第29図. $\mathrm{ACh}$ のカェル腹直筋収縮に及ぼす PVL の影樂. $13 / \mathrm{XI}{ }^{\prime} 56,17^{\circ} \mathrm{C}$, 管内液量 $10 \mathrm{cc}$, 時標 $30^{\circ}$ 。 90 の収縮を示守。

A : $10^{-7}$ ACh Ringer 液,

$\mathrm{P}$ : PVL. 数字は投与量 (cc), $+: 5^{\mathrm{m}}$ 後溶液の交换. 


\section{2. 血清 ChE に対する PVL の作用}

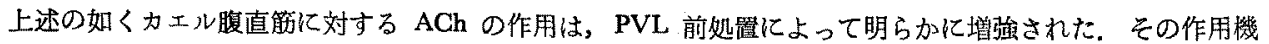
序として当然 PVL の抗 ChE 作用が考兄られる。そこで著者は，血清中の ChE に対する作用を，化学的試験 法並びに生物学的試駼法によって梌索した。

\section{1) 化学的試験}

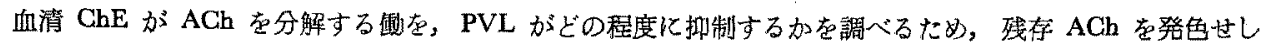
め，その吸光度を光霞比色計を用いて测定する方法を利用した．测定の実施はHestrin ${ }^{37}$ 及び桶口ら ${ }^{28}$ の ChE 活

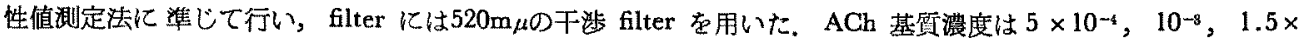

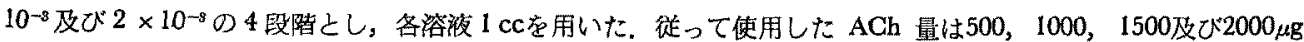
てある。

まず ACh の各浱度の水溶液を型の如く発色せしめ て收光度を湘定した，各溶腹は $\mathrm{ACh}$ の濃度に応じた淡 より浀に至る特有な色調尼星し，それと其に财光度もは

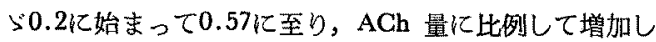
た (第30园 $\Delta$ ).

ヒト血清を蒸溜水を以て10倍に稀秎し，その1 ccを 各 $\mathrm{ACh}$ 溶液に作用せしめた季のは，何れも全く發色せ ず，徉って吸光度はは 0.07 前後であり，水(吸光度 0 ) に近い值を示した（第30風 $\times$ ).

次にヒト血清 $1 \mathrm{cc}$ 刘して濃度 $10^{-4}$ の Neostigmine 溶液 $0.25 \mathrm{cc}(=25 \mu \mathrm{g})$ 渠加し, 弥溜水屋以て全量 $10 \mathrm{cc}$

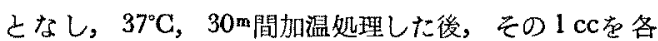
$\mathrm{ACh}$ 浴液に作用せしめて検すると，ChE の作用は殆ん ど完全に抑制され，その吸光度は佸ら゙ACh 算独の水溶 没の示した値に近似した（第30昌）。

そこて Neostigmine の代りに PVL を血清に加光

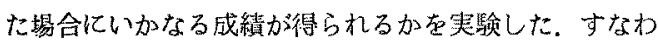

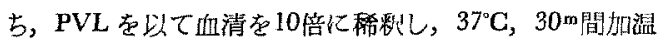
後をの $1 \mathrm{cc}$ ⿸用いて $\mathrm{ACh}$ 溶液に作用せしめ，各浴液の 発色を検する上，何れ皇色が認められず，徉ってをの 败光度は ACh に血清を作用せしめた糃会と同粎に0.07 前後の值を示した（第30図○）.

以上の奏験成績の示打く，本実験方法虏むってし

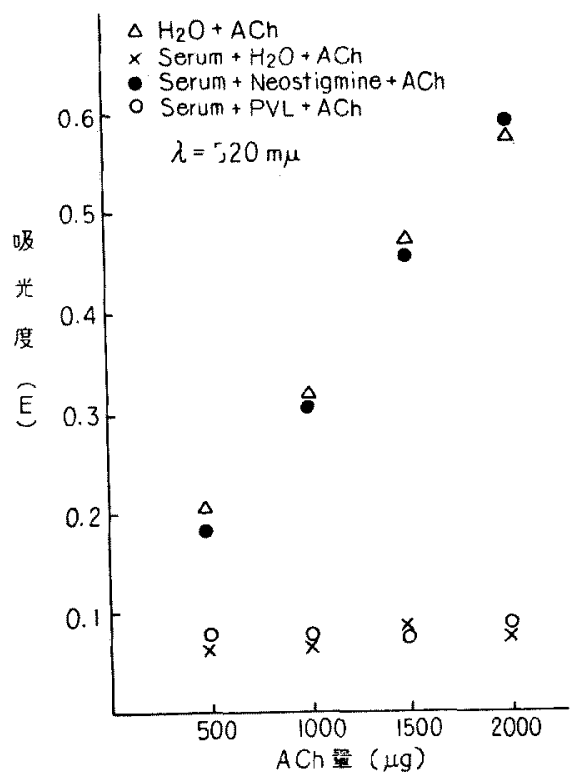

第30図. PVL の抗 ChE 作用に喂する 化学的試釱 (Hestrin 法).

Serum：ヒト10倍桸粎血潜 $1 \mathrm{cc}$. PVL : 0.9cc.

Neostigmine $: 2.5, \mathrm{Lg}$ ては PVL の抗 ChE 作用を証明するこしは出来なかった。

\section{2) 生物学的試銆}

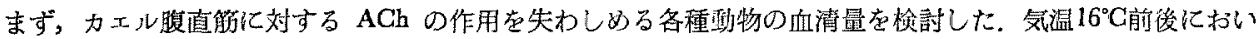

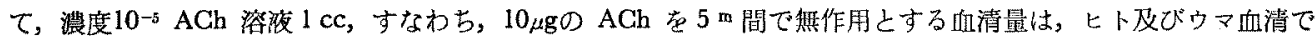
は0.1ccて立分であったが，ウサギ伹清では0.2ccを要した。

以下の実験ではウマ血清を用い，その0.1cc中の ChE 活性度に対する PVL の影響を調へ，併せて Eserine

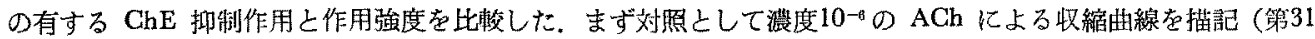

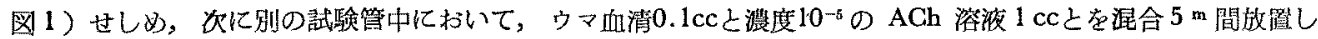

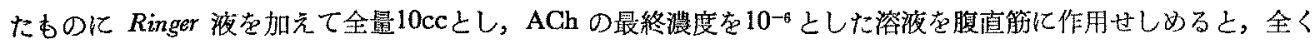
収縮は認められない(第31园 2 ).

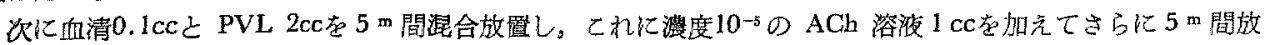


夫

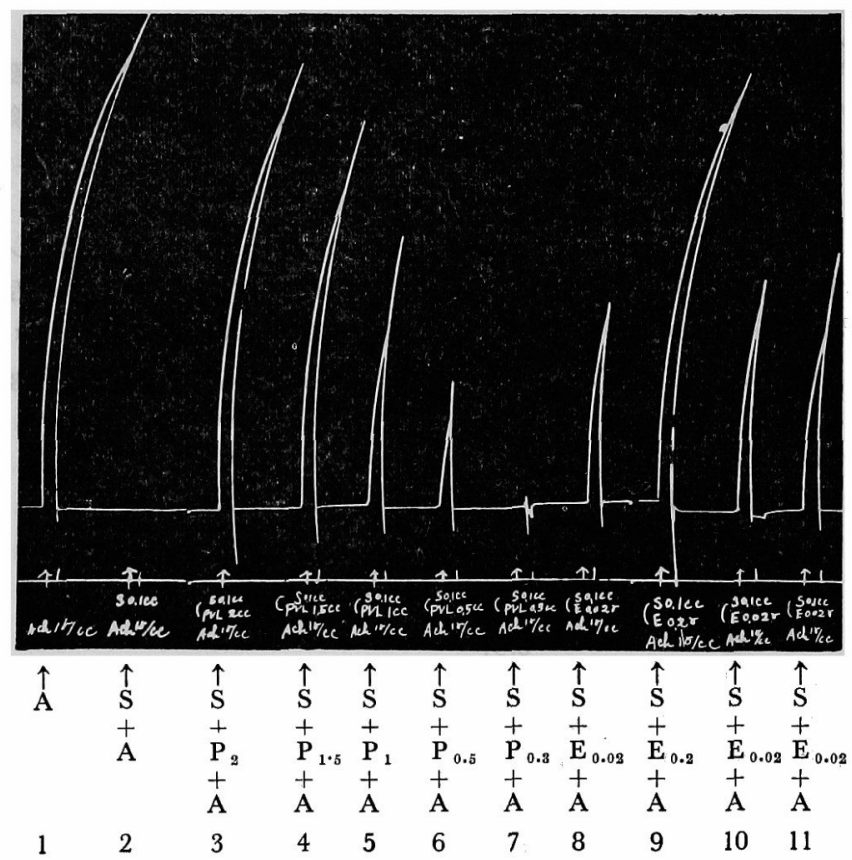

第31図. PVL の抗 ChE 作用に関する生物学的試跧 (カエル腹直筋による实験).

$1 / \mathrm{X} \|$ ' $56,16^{\circ} \mathrm{C}$ ，管内液量 $10 \mathrm{cc} ， 90^{\prime}$ の収縮を示す。 $\mathrm{S}$ : 馬血清0.1cc, E : Fserine, 数字は投与量 $(\mu \mathrm{g})$, A : $10^{-6} \mathrm{ACh}, \mathrm{P}: \mathrm{PVL}$, 数字は投与量(cc), $+:$ in vitro $6 \tau 5 \mathrm{~m}$ 間反応.
置した後，Ringer 液を加えて全量を $10 \mathrm{cc}$ としたのを腹直筋に作用せし めると，ほづ対照に近い収縮が現わ れた (第31図 3). 同様操作で PVL の量を1.5，1，0.5，0.3ccと次第に 減量して血清 ChE 活性度に対する 影響を観察すると, 腹直筋の収縮高 は PVL の量に応じて段階的に低下 するのがみられ，1 ccでは $2 \mathrm{cc}$ 用 いた場合の約 $50 \%$ 収縮高となり， 0.3 ccでは全く収縮が認められない (第31図 $4 \sim 7$ ).

以上の実験によって PVL は抗 ChE 作用を有することが判明した ので，次にその作用強度を Eserine のそれと比較する契験を行った．こ の両者の作用強度を比輘するのに， 夫々対照值のほ 量を目標としたが，その結果はPVL

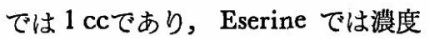
$2 \times 10^{-8}$ 溶液 $1 \mathrm{cc}$, すなわち $0.02 \mu \mathrm{g}$ であった（第 31 図 5 及び 8, 10, 11). 次に PVL の抗 ChE 作用の対 血清有效時間を検索した。 すなわち， PVL と血清との反応洔間を $5 ， 10$, $15,20,30 \mathrm{~m}$ と種々に変化せしめて

众した所，その作用は $5 \mathrm{~m}$ において最高を示し，それ以上反応せしめると次第に減弱して20〜30m間反応せしめ た場合には，全く無効となることを知った。

\section{3.小 括}

PVL と ACh の作用比粉並びに相互の関係を検索すべく，カエル腹直笳を用いて実験を行った，PVLは単 独では腹直筋を収縮せしめないが，その前処置は明らかに ACh による収縮を増強した。

次に PVL の ACh 増強作用の作用機序を解明すべく，化学的試験法によって抗 GhE 作用を証明せんとし たが，全く認む得なかった。 しかし，カエル腹直筋を用いた生物学的試験法によって，PVL の血清 ChE に対 する影響を锥察すると，明らかに抗 ChE 作用が証明され，その作用強度は PVL 1 ccを用いた場合，Eserine $0.02 \mu \mathrm{g}$ の作用に匹敵した. しかし，PVL の抗 ChE 作用の持続は短かく，血清との反応時間 $5 \mathrm{~m}$ で最高の抗 ChE

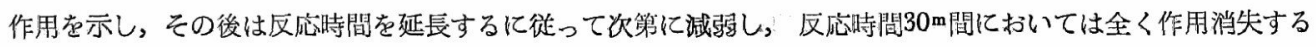
ことを知った。

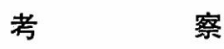

全身作用 : 著者は種々の浭物に PVL の比校的大量を非経口的に与え，その全身作用を観察した. マウスに はその 1 ccを限度として注射したが，その症状は洗顔動作，体をなめる動作などの外は運動不活潑，食愍不振な

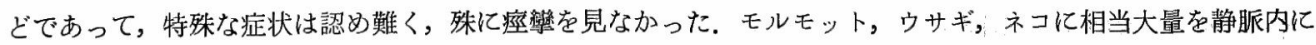
注射しても特別な症状は見られず，就中ネコには10ccの静脈内注射を行ったが殆んど何等の症状を認めることが 


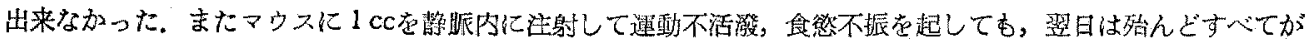
回復しており，奏験例 6 例中死亡したものは 1 例に過ざなかったために，LD50屯算出するととが出来なかった。

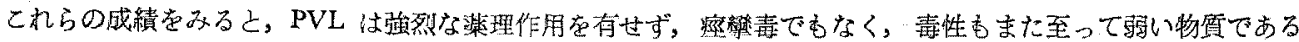

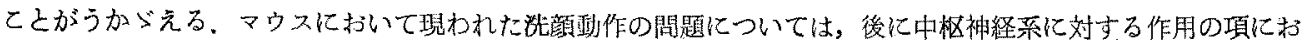
いて触れたいよ思う。

循環系に対する作用：生体内心臟亿刘する PVL の作用をみると，カエル Engelmann 法では0.2ccを能脈内

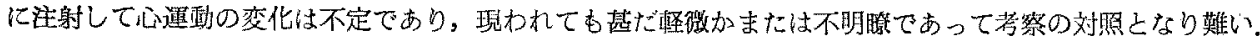

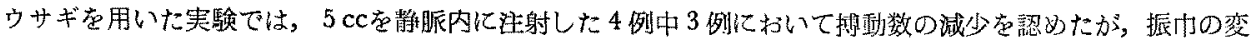
化は明らかでなく，縮小はしないが確実に增大するとは云い切れない成績を得た．従って心欌の効率にどれだけ

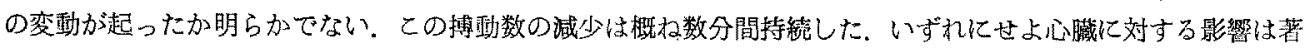

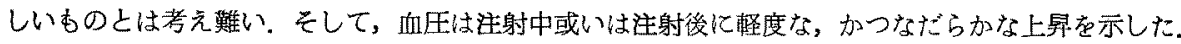

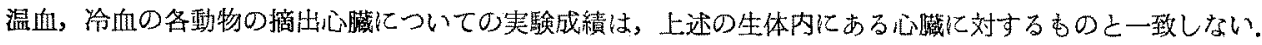
著者はこれに種々な実験方法を用いたが，乙れ方法の上から2種数に分けることが出来る。その1つはカエル

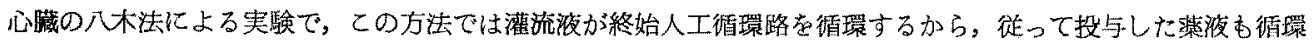
し，一旦作用させれば奏験中終始作用し続け，他入流れ去ることがない．とれに対して，力エル心藏の田村・小

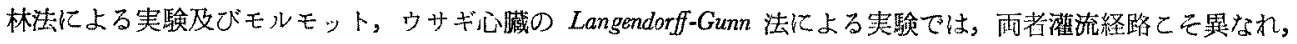

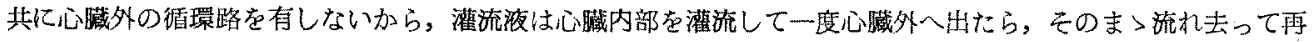

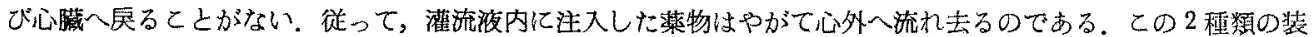
置の遠いによって PVL の作用は違って現われた。八木法によって行ったカエル摘出心臟の実験ては，PVL 0.2 ccの投与によって振巾の縮小が起り，加つ收縮拡張共に不良となる。搏動数も僅かながら娍ずる。乙机らの变化 はさして著しいあのではないが，終炲明らかに心臓抑制作用のみる現わしている，次に田村・小林法による実驗

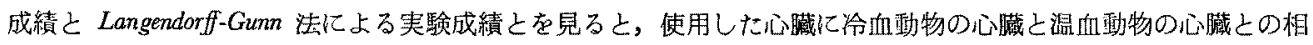

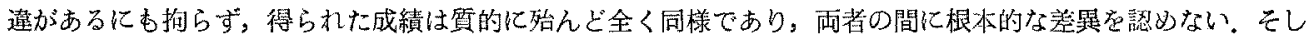

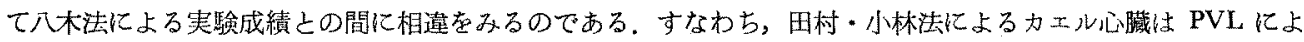
って，まず収縮及び拡張装に著しく不良となり，撕動数は多少增加するが，搏出量としては甚しい減少す示す。 次に収縮抁張共に著明に增加し，搏動数は減ずるが搏出量は著しく增大する。乙れ要約すれれ゙初期心蔵機能は 抑制され，ついて促進に变化するのであって，両者共にかなり著明でる。 Langendorff-Gunn 法によるモルモッ トまたはウサギ心葴は PVL を作用せしめた初期20３030間収縮拡張共に著しく不良となるが，直ちに增大に

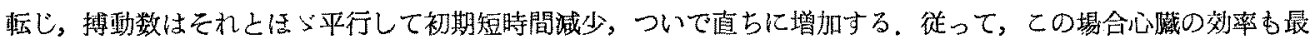
初覀くなりついで良くなることは間遠いのないことであって，初期心咸抑制作用，ついで促進作用となること领 血動物の埸合と全く同梾である。

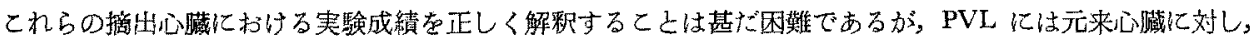
抑制作用と促進作用との相反する 2 程類の作用が内蔵されており，夷験方法によって後者か現われること〉，現

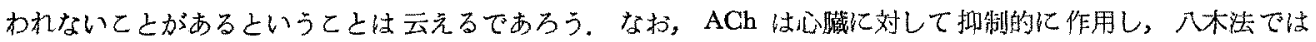

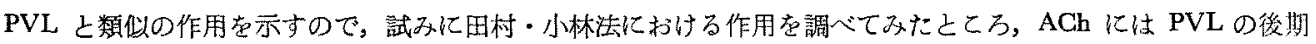

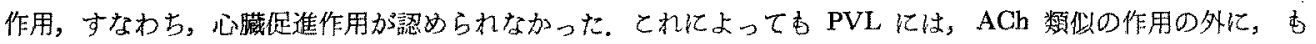
う一つとれとは買質の作用のあるととがうから゙われる。

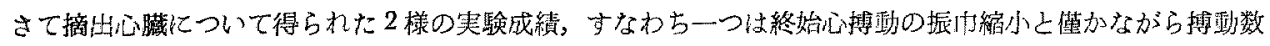

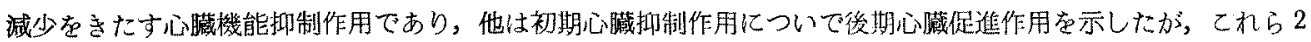

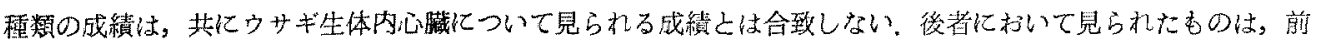

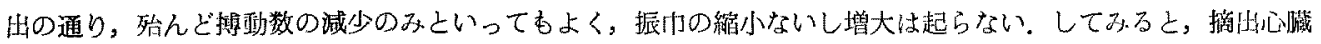

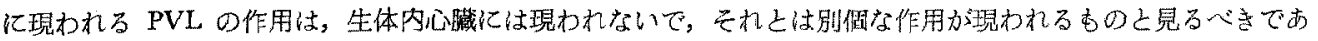
万う.

しかしながら，著者は PVLに弱いながらす ChE 抑制作用のおることを䓰明し得たから，この作用との関 


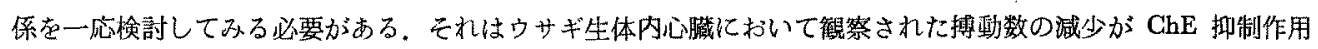

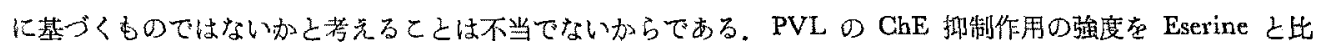

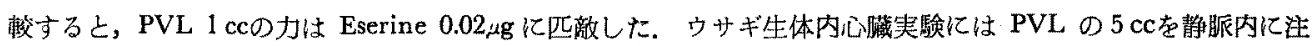
射しているから，乙の最は Eserine $0.1 \mu \mathrm{g}$ 亿相当する。乙の Eserine の最は，ウサギ循環系をの他て变化を及ば す量ししては余りに小量である，通常ウサギに静眽内に注射して何らかの作用を現わさしひるには，Eserine 0.1 $\mathrm{mg} / \mathrm{kg}$ 以上它必要とする。乙の量は PVL $5 \mathrm{cck}$ 相当した Eserine 量 $0.1 \mu \mathrm{g}$ 数干倍量に当る．乙の計算加ら考

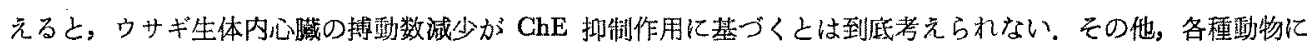

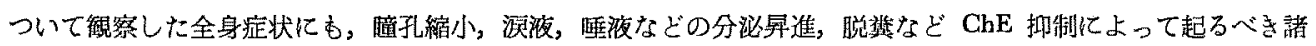

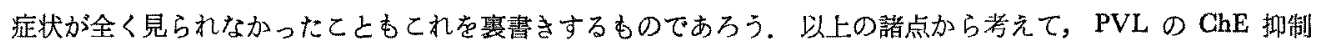
作用は，をの棊理作用には関係しはいあのと考えたい.

心搏動淢少をすたらす機序は一つではないから，実鍳的根拋なしには何とす云えないか，著者はある锥点か

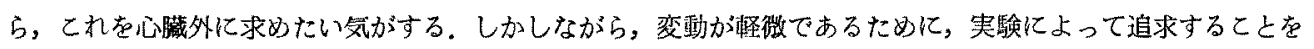
しなかった，今後の研究にまちたいと思う。

末梢血管については，PVL は岡田法によるガマ後肢血營灌流実験にわいて，夏季は拡張，冬季忙収縮作用

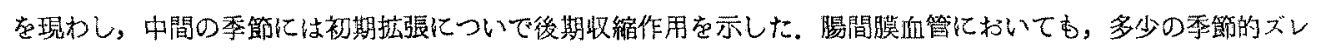
を別にすれぱはぼ同様の成績を示した。

冷血動物の藏器が雪節によって暴なった反応を示すととは多くの例があって，あえて坚しむに足りないが， 夏冬の中間の季節に，初期拉張についで後期収縮作用が継起することは，やはり PVLに恒反する2種類の作用 が内蔵されていることを示すすのではなからうか。因みに ACh には雪節の如何にわ〉わらず常に拡張作用のみ が見られたからこの埸合にもACh との相遠が現かれている。

埧血動物の血管が冷血動物の血管亡同様の反応を示すか否かは不明という外はないが，温血動物生体内血管 が PVL の注射によって如何なる変勘を示すかについて若干の考察を行ってみたい. 蔇述の如く，ウサギ生体内

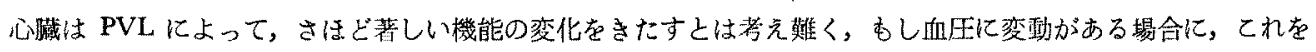

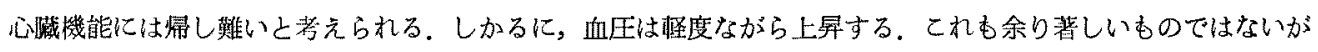
極めて埾度に，なだらかに上畀するのが珰められる。注射中の血圧上昇は，或いは汪射の操作自体によって起る

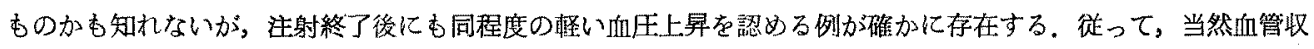
縮による血王上昇を考えざるを得ない。

この考えに基ついて，著者は実験る行い，その結果 PVL 亿著明な血管連動神経中权與屚作用のあることる 証明するととが出来た，ウサギにChloralis hydras 与えて血厓下降を起させ，てれにPVL 5ccを静脈内に注射

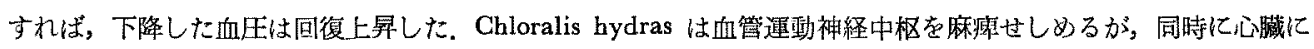
対しても麻序的に作用するから，血圧下降には2要素加合まれている，従って，乙れに拮抗して血圧を回復上昇

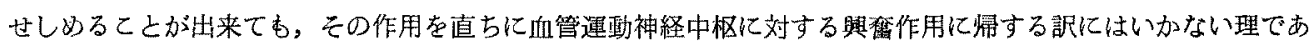

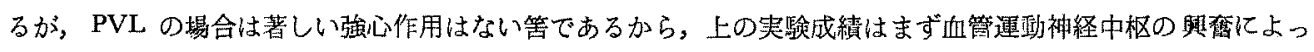
て血管が取縮したものと解してよからう。これに対し，ガマSchmidt 法による実験成緽は最あ端的に，かつ明ら かに血管運動神経中权に詨する興唒作用の存在を証明し得たものである。

埧血動物の血管に対する PVL の直接作用は不明であるが，著者はPVLによる軽度の血压上昇作用は，主

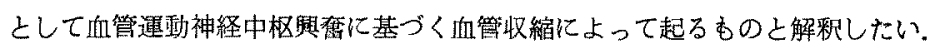

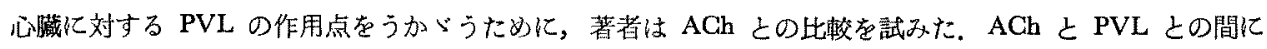
は，作用に相違があることは先にも述べだ，対 Atropine 関係においてもとれを見るととが出来る，AChの 作用は Atropine によって全く抑制されるのに反し，これとはく同程度の作用强度を有する PVL の作用は，

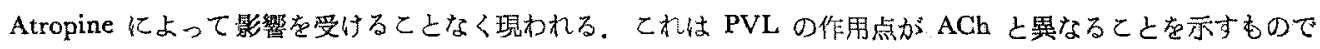
あるが，大量の Atropine と相互に拮抗するにわいては，PVL の心缄抑制作用は主として心能自体に対する作 用上考兑て善支觉なからう。

以上の関係は，ガマ後肢血管に対する PVL の搪張作用についても全く同様である。なお，血管については， 


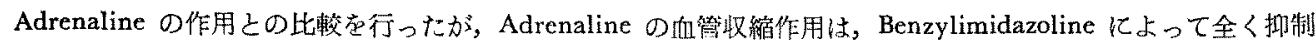
されるのに対し，PVL の血管饨縮作用は Benzylimidazoline に影響されることなく現われた。このとさは， PVL が Adrenaline とす作用譏序異にするととを柰するのであるが，さらに Benzylimidazoline と PVLと の間には相互拮抗関係があり，との点については $\mathrm{BaCl}_{2}$ 上同様であるととから，収縮作用についてす PVLは

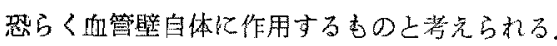

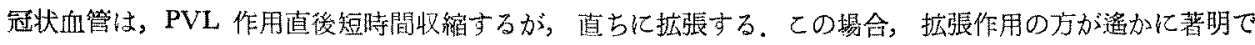

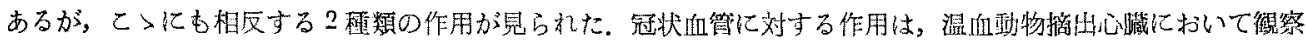

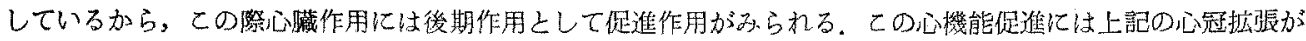
多分一部関与するものと思われる。

腸管に対する作用 : 著者はウサギ及びネコについて，之の生体内にある锡合の腸管に対する PVL の作用荧

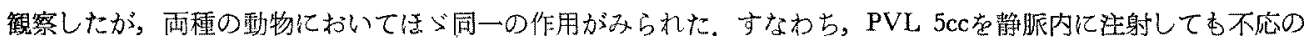

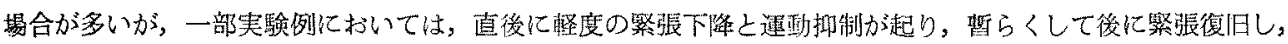

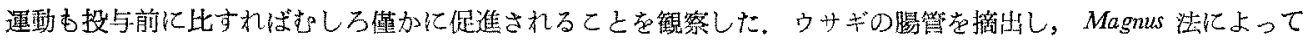
実験を行った成績では，PVLによってまず一洞性の振币縮小が起るが，その期間は極めて短く，続いて柾度の

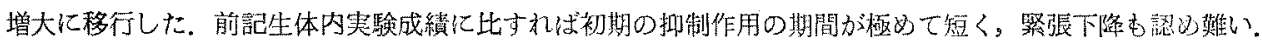

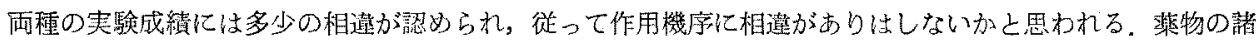

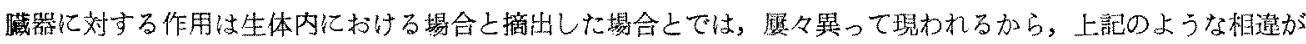

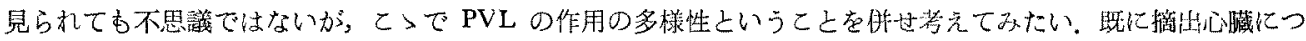

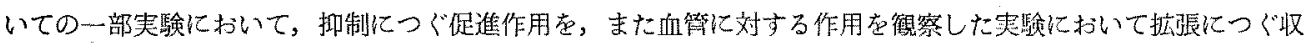

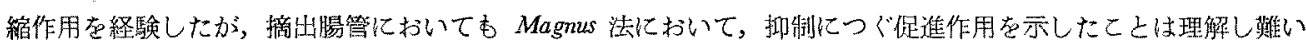
剚柄である。

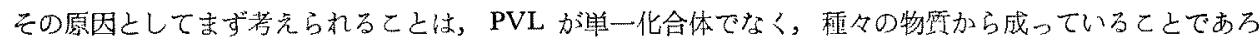

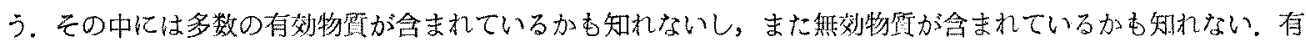

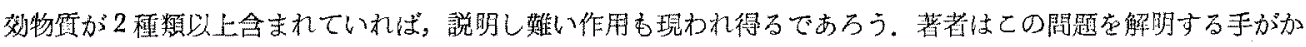
りとするために，PVL をセロファン膜を以て透析した透析内液上透析外液とが，腸管に対して如何なる作用を

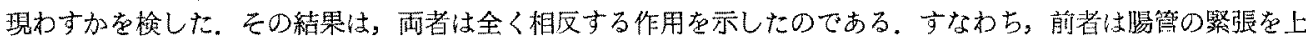

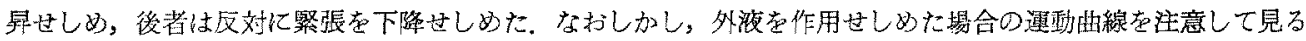

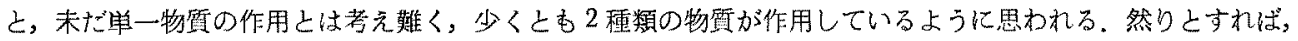
内浚中の有効物侗を 1 種類之仮定して，摘出腸管に対する作用物犋は少くとも 3 種類となるわけである。

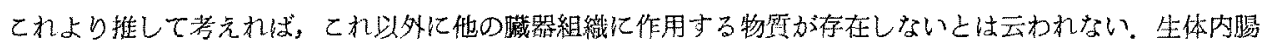
管と摘出腸營との間に作用の相違があるとすれば，てれは寒験方法の違いに基づくあのであるか，てれとも作用

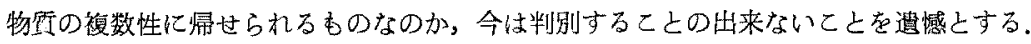

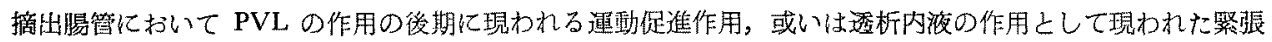
上輩作用については，Atropine その他三，三の薬物を併用して作用点虑うから゙った. ACh 及び PVLの Atropine に対する関係支見た結果によるよ，ACh の作用を抑制子る Atropine 量によって PVL の作用は抑制され ない. 大量の Atropine を用うれば，PVL の繁張上昇が抑制され， $\mathrm{MgSO}_{4}$ とは相互に捛抗関係を示した。 乙 れらの成績加ら考えて PVL の作用点は主として腸管平滑腹にあると思われる。

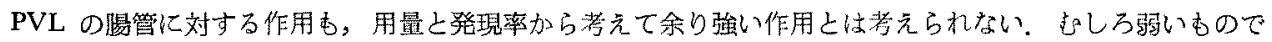
あらう.

子宮に対する作用：PVL はウサギ非妊子宮に対して，生体内にある埸合でる，摘出した掦合でも，共に暝

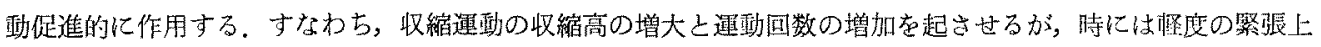

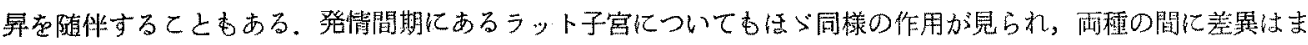
ずない，たら゙ウサギにおける来験に执て，摘出子宦の堨合には PVL の作用が直ちに現われるのに対し，生体

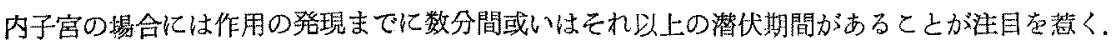




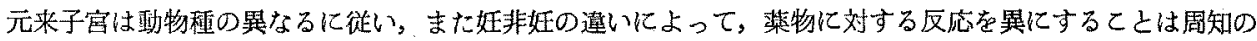
事実であるが，著者が非娃りサギと非妊ラットの摘出子宦について見た PVL の作用は，既述の如く，共に運動 促進的であって 2 者の間に相違を認めなかった。

Adrenaline が，ウサギ子宮に対しては運動促進的に，ラット子宮に刘しては運㳩挪制的に作用するととは，

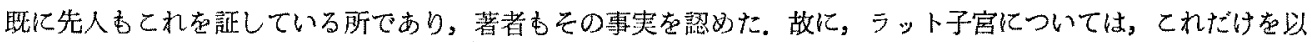
て既に PVL とAdrenaline とは作用機序異にすることが明らかであるが，ウサギ子宫についても Benzyli-

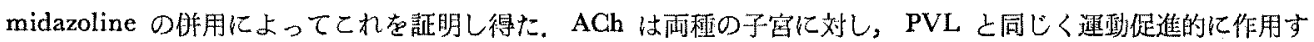
るが，その作用機序の相違は Atropine の併用により，特にラット子富において明らかにすることが出来た。 PVL が Adrenaline，ACh の両者と作用点を䔬にすることは，子宮筋效して特異な作用点に作用するすので ないことを物語るが，さらに $\mathrm{MgSO}_{4}$ と相互に拮抗関係を示したことによって，主として子宫筋自体に作用する むの上梕めてよかるうと思われる。

呼吸に及ぼす影畋：PVL の呼吸促進作用はかなり顕著なものであって，著者の钼繁した諸作用のうち，最

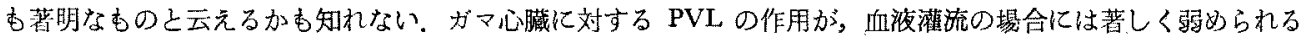
ととを考えると，むしろ奇異の感を抱加せるむのがある。

PVL の呼吸促進作用は，ウサギに静眽内に $5 \mathrm{cc}$ 注射した場合の呼吸曲線にも明らかに锶取されるが，

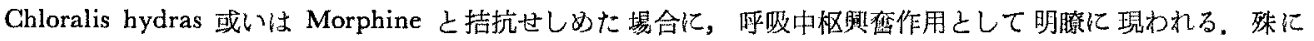

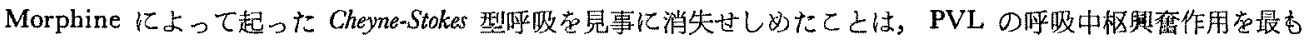
よく証明し得だすのである。

著者はまた，種々の方法を用いて PVL の気管または気管支平滑筋に対する弛紱作用をも証明した。この作 用は著明とは申し難いが，気管または気管支の拡張が呼吸運動促進に一部関与するかも和れない，たらし，モル モット気管支灌流害験法においては，作用の初期に一過性の収縮作用が発現した。 これも PVLの作用物質の複 数性を物語るものであろう。

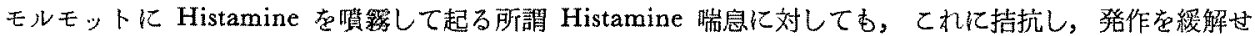
しめた，この実験において，時に煓息発作を助長するかの如き逆效果を現わす埸合のあること〉，抗-Histamine

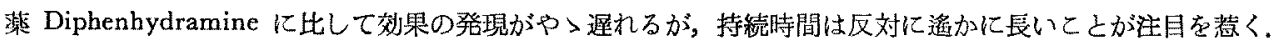

作用点については PVL の気管拡張作用が Histamine と相互に拮抗する点からみて，気道平滑筋自体であ ろうと考えられる。ACh とも拮抗作用を示すが，ACh の作用が Atropine によって抑制されるのに対し，PVL

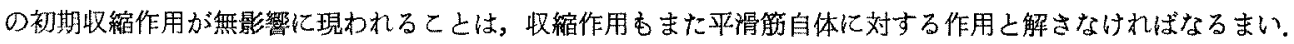

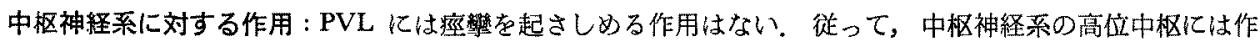
用しないものと思われる。しかし，既述の通り，血管運動神経中枢及び呼吸中枢に刘しては著明な興檑作用を示

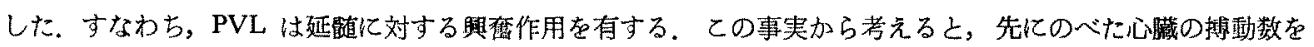

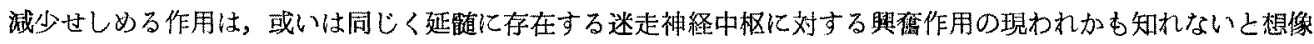
する。

また，マウスに対する全身作用を㓋察した実験において，所謂洗顔勘作がやつ旺になることを見た。乙の動

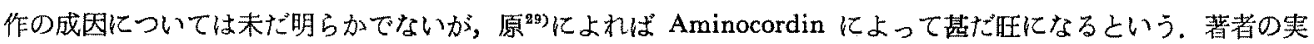
験では，刘照実驗として行った生理食盗水の注射によってもての動作か現われ，PVLによってはそれよりもや 〉持続時間が長いだけで, 特に著しく旺盛となったと屯思われないからこの現象を余りに重視し，てれを PVL

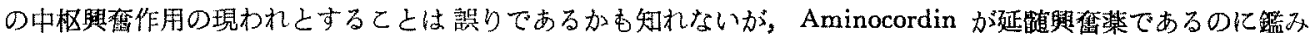
て一応考察学加えてみた次第である。

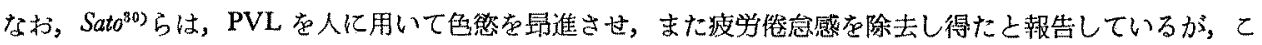

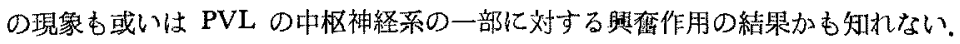

とまれ PVL の呼吸中权立びに血管運動神経中枢に刘する與舊作用は蕃明であって，PVL の有する作用の うちで重要性の大なるすのと考えたい。

以上著者は PVL の作用の薬力学的研究の成果について一通りの考祭を試みたが，その作用はかなり複雑で 
あって，首尾一貫した，かつ明睹な解粗を得ることが国難であり，なお間題を今後に残した部分が少なくない． これは，一には著者の研究に不允分な点のあることにあよるがまた PVL そのあのが多種類の物質の混合物で

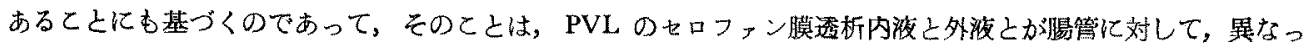
た作用を現わすととによってあ充分うから゙えることである。著者は，今日まで獎理学的には殆んど検索されたと とのなかった PVL の作用を研究し，その一面を明らかにすることが出来たと侵ずるが，なお无分ではない，今

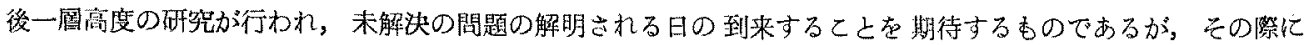

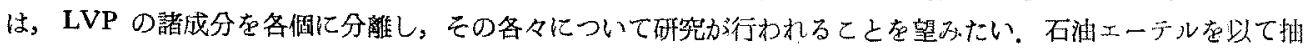
出を行うことの是非香汃くて明らかに世られるであろう。

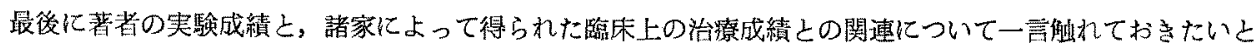

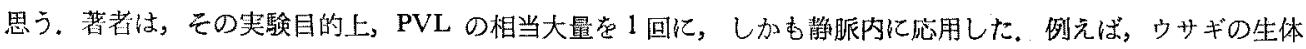
内心臟或いは腸篦に対する作用を見る奏験において，静眽内に $5 \mathrm{cc}$ 注射した，時にはもっと大量を用いた掦合 あある。これら沽臨床上に用いられる量に比して甚しく大量であり，加適用経路を異にする，監床上には，通 常0.2２.0cc程度の小量在皮下若しくは皮内に用いて衫り，加何回加の注射を行って1タ一ルとする方法が採

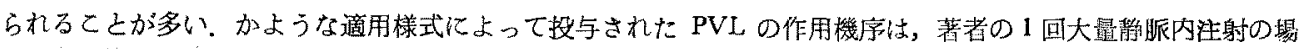
合のそれとは同一でない可能性が充分ある，加上うな可能性は，ひろく一般薬物の作用として考えてもあり得る

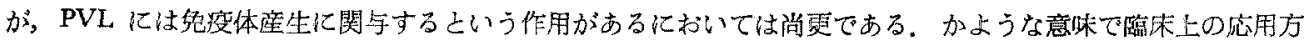
法では PVL が何らかの経路によって，生体の化学過硅に影響を与え，それによって二次的，三次的に作用する

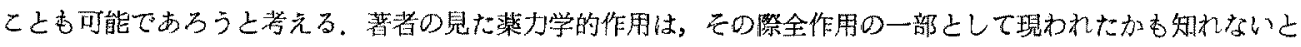
想像する次筙である。

総括

1. 著者は PVL の蒜理作用を菲力学的に研究した，使用した PVL は石油エーデルによる抽出を行わず， また石炭酸及び䢧を加えてないものである．製品はすべて同一原料粗萌より製造せられたすのであり，発痘力試 験にわいて規定の力做を示した。 セロファン膜を以て $24 \mathrm{n}$ 透䉼した透析内液と外滩とについて発痘力を調べたが， 前者にあって後者にはない.

2. 動物に PVL の相当な大量を非経口的に投与しても，特記に值する程の症状を呈さないまた死しする ととあ稀である。毒性弱き物覆之思われる。

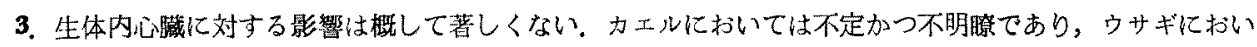

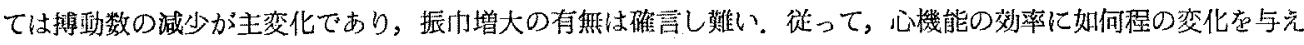

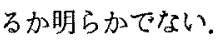

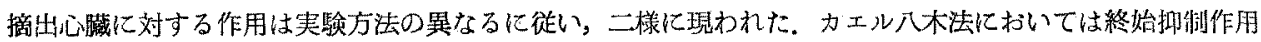

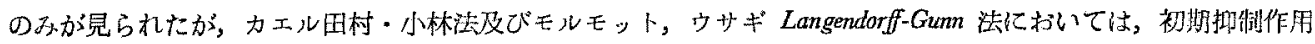
についで後期促准作用が発現した。

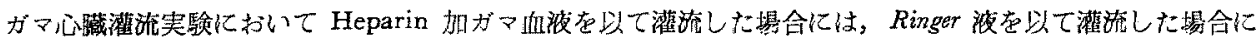
比し，PVL の作用は著しく弱められる。

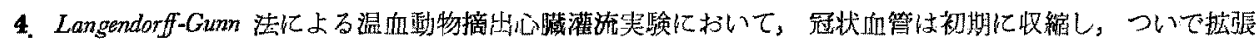
した.

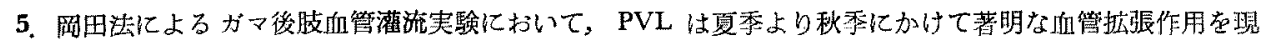

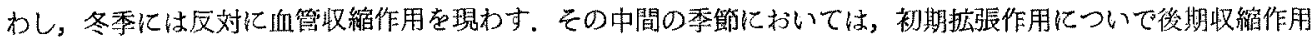
が継起する。

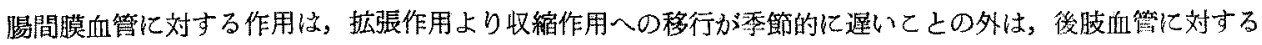
作用とはら゙同様である。

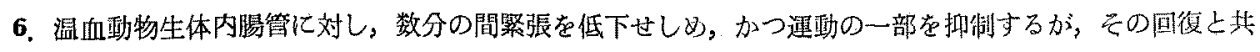




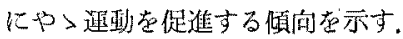

ウサギ摘出腸管は直㣞一過性の振门縮小の後に振门の堌大をきたすが，モルモット渴管は極めて短時間の繁

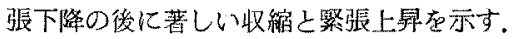

ウサギ摘出腸管は，PVL のセロファン膜透析内液によって緊㖘上舁を示し，透析外液によって，まず運動 振わが縮小し，ついで祭㖘下降を示した。これは PVL 中に多くの有效物質が存在するととを暗示するすのであ 万.

7. 非娃ウサギ生体内または摘出子舅飞刘し，運動促進作用を示し，ラット登情間期子宮に対しても同㥞の 作用がある。

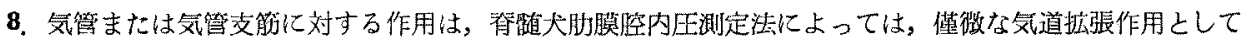
現われ，気道可滑筋に刘する弱い驰綬作用の存在がうから゙われた。

モルモットまたはウサギの摘出気管筋については，大部分の例においててれる認めることが出来ず，唯 $\mathrm{ACh}$ 及び Histamine に対して高度な感受性を示す標本においてのみ弛䊣作用が認められた。

モルモットの摘出肺蔵気管支灌流実験では，初期一過性の収縮につ〈゙持続的な㹡張を示す二相性の作用が認 好られた。

9.モルモット Histamine 喘息に拮抗しててれを䌅解する。るの作用を Diphenhydramine のそれと比校

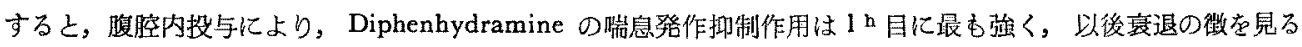

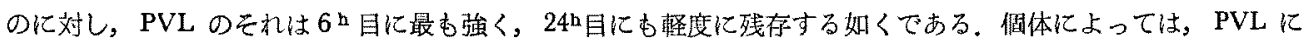
よって初期 Histamine 踇息が却って助長されてるものがある。

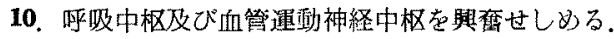

11. 極むて弱い ChE 测制作用を有する。

12. PVL の諸藏器に対する作用点については，PVL の作用が複雑であるために，钼察した作用のすべてに ついて检索することは出来なかったが，諸種の菲物を併用した結果，次の諸作用については主な作用点以筇肉自

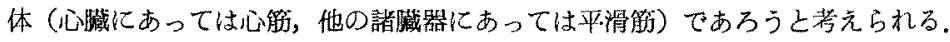

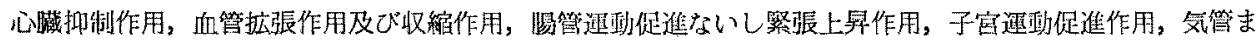
たは気篦支拡張作用及び収綰作用.

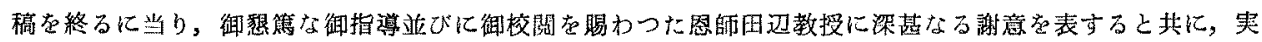

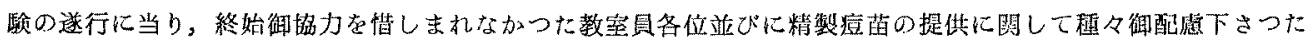

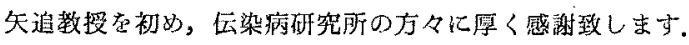

\section{引用 文 献}

1) Yaoi, H. \& Kasai, H. : Jap. J. Exp. Med. 7, 243 (1929).

2) Yaoi, H. \& Arakawa, S. : Jap. J. Exp. Med. 17, 379 (1939).

3) 矢遑：東京医事新誌 3127 号, 779 (1939).

4) 矢追：実験医学誌 26, 84 (1942).

5) 矢追, 榷原, 留岡: 東京医职新誌 3176 号, 519 (1940).

6) 山田：契験医学誌 25, 131 (1941).

7) 矢追：横浜医学 2, 14 (1951).

8) 矢追：基礎と臨床 1, 25 (1947).

9) Yaoi, H. : Yokohama Med. Bull. 2, 69 (1951).

10）野口：日本医事新報 1800 号, 29 (1958).

11) Yaoi, H., Takei, M. \& H. Maeda : Yokohama Med. Bull. 2, 35 (1951).

12) 相見：日本小昌科学会雑誌 56, 314 (1952).

13) 相見：同誌 58, 272 (1954). 
4) 相晃: 同詰 58, 219 (1954).

15) 原生省：生物学的製削基準 p. 1 (1958).

16) Okada, M. et al. : Jap. J. Med. Soc. trans IV. Pharmacol. 8, 17 (1934).

17) Stephenson, R. P, : J. Physiol. 107, 162 (1948).

18）矢田貝：日本外科宝西 7, 附録 (1930).

19) 啮田：医学綜報 3, 2 (1949).

20) Jackson, D. E. : Experimental Pharmacology, St. Louis C. V. Mosby Co. p. 196 (1917).

21) Mary D, McDougal \& G. B. West : Brit. J. Pharm. 8, 26 (1953).

22) Ther, L. : Pharmakologische Methoden, Wissenschaftliche Verlagsgesellschaft m. b. H. Stuttgart, p. 262 (1949).

23) Kallas, P. \& W. Pager : Acta. Med. Scand. 91, 292 (1937).

24) Schaumann, O. : Arch. Exp. Path. Pharm. 196, 109 (1940).

25) Loew, E. R. et al. : J. Pharm. Exp. Therap. 83, 120 (1945).

26) Burn, J. H., 松田腾一訳 : Practical Pharmacology, p. 3 (1956).

27) Hestrin, S. : J. Biol. Chem. 180, 249 (1949).

28）粗口，五昧：日本医事新報 1536 号，11(1953).

29) 原 (三郎) : 琵話.

30) Sato, K., Turumi, N. \& K. Murakami : Yokohama Med. Bull. 7, 207 (1956). 